\title{
A Guide to Geothermal Energy and the Environment
}

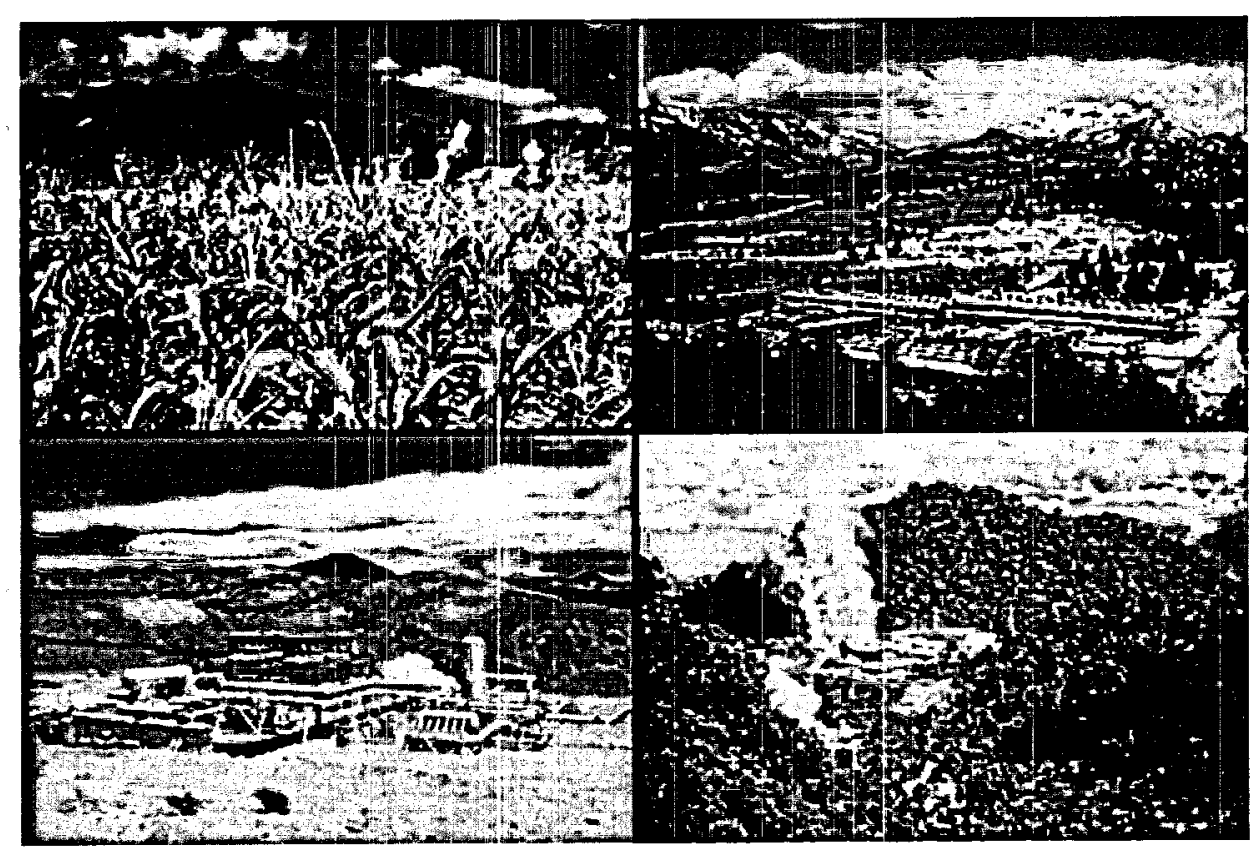

Written By Alyssa Kagel, Diana Bates, \& Karl Gawell

GEOTHERMAL ENERGY ASSOCIATION

209 Pennsylvania Avenue SE, Washington, D.C. 20003

Phone: (202) 454-5261 Fax: (202) 454-5265

Web Site: www.geo-energy.org

April 22, 2005 


\section{DISCLAIMER}

This report was prepared as an account of work sponsored by an agency of the United States Government. Neither the United States Government nor any agency Thereof, nor any of their employees, makes any warranty, express or implied, or assumes any legal liability or responsibility for the accuracy, completeness, or usefulness of any information, apparatus, product, or process disclosed, or represents that its use would not infringe privately owned rights. Reference herein to any specific commercial product, process, or service by trade name, trademark, manufacturer, or otherwise does not necessarily constitute or imply its endorsement, recommendation, or favoring by the United States Government or any agency thereof. The views and opinions of authors expressed herein do not necessarily state or reflect those of the United States Government or any agency thereof. 


\section{DISCLAIMER}

Portions of this document may be illegible in electronic image products. Images are produced from the best available original document. 


\section{Executive Summary}

\section{INTRODUCTION AND OVERVIEW}

Geothermal energy, defined as heat from the Earth, is a statute-recognized renewable resource. The first U.S. geothermal power plant, opened at The Geysers in California in 1960 , continues to operate successfully. The United States, as the world's largest producer of geothermal electricity, generates an average of 15 billion kilowatt hours of power per year, comparable to burning close to 25 million barrels of oil or 6 million short tons of coal per year. ${ }^{1}$

Geothermal has a higher capacity factor (a measure of the amount of real time during which a facility is used) than many other power sources. Unlike wind and solar resources, which are more dependent upon weather fluctuations and climate changes, geothermal resources are available 24 hours a day, 7 days a week. While the carrier medium for geothermal electricity (water) must be properly managed, the source of geothermal energy, the Earth's heat, will be available indefinitely.

A geothermal resource assessment shows that nine western states together have the potential to provide over 20 percent of national electricity needs. Although geothermal power plants, concentrated in the West, provide the third largest domestic source of renewable electricity after hydropower and biomass, they currently produce less than one percent of total U.S. electricity.

\section{EMISSIONS}

The visible plumes seen rising from some geothermal power plants are actually water vapor emissions (steam), not smoke. Because geothermal power plants do not burn fuel like fossil fuel plants, they release virtually no air emissions. A case study of a coal plant updated with scrubbers and other emissions control technologies emits 24 times more carbon dioxide, 10,837 times more sulfur dioxide, and 3,865 times more nitrous oxides per megawatt hour than a geothermal steam plant. Averages of four significant pollutants, as emitted from geothermal and coal facilities, are listed in the table below. Following the table is a brief discussion of other emissions that have sometimes been associated with geothermal development.

\footnotetext{
${ }^{1}$ Using Energy Information Administration (EIA) average geothermal energy production, 1990 - 2003, and EIA conversion information
} 


\begin{tabular}{|l|l|l|l|l|}
\hline Emission & $\begin{array}{l}\text { Nitrogen oxide } \\
\text { (NOx) }\end{array}$ & $\begin{array}{l}\text { Sulfur Dioxide } \\
\left(\mathbf{S O}_{2}\right)^{*}\end{array}$ & $\begin{array}{l}\text { Particulate Matter } \\
\text { (PM) }\end{array}$ & Carbon Dioxide $\left(\mathbf{C O}_{2}\right)$ \\
\hline $\begin{array}{l}\text { Sample } \\
\text { Impacts }\end{array}$ & $\begin{array}{l}\text { lung irritation, } \\
\text { coughing, } \\
\text { smog } \\
\text { formation, } \\
\text { water quality } \\
\text { deterioration }\end{array}$ & $\begin{array}{l}\text { wheezing, chest } \\
\text { tightness, } \\
\text { respiratory } \\
\text { illness, } \\
\text { ecosystem } \\
\text { damage }\end{array}$ & $\begin{array}{l}\text { asthma, bronchitis, } \\
\text { cancer, atmospheric } \\
\text { deposition, visibility } \\
\text { impairment }\end{array}$ & $\begin{array}{l}\text { global warming } \\
\text { produced by carbon } \\
\text { dioxide increases sea } \\
\text { level, flood risk, glacial } \\
\text { melting }\end{array}$ \\
\hline $\begin{array}{l}\text { Geothermal } \\
\text { emissions } \\
\text { (b/MWh) }\end{array}$ & 0 & $0-0.35$ & 0 & $0-88.8$ \\
\hline $\begin{array}{l}\text { Coal emissions } \\
\text { (b/MWh) }\end{array}$ & 4.31 & 10.39 & 2.23 & 2191 \\
\hline $\begin{array}{l}\text { Emissions } \\
\text { Offset by } \\
\text { Geothermal } \\
\text { Use (per yr) }\end{array}$ & $\begin{array}{l}32 \text { thousand } \\
\text { tons }\end{array}$ & 78 thousand tons & 17 thousand tons & 16 million tons \\
\hline
\end{tabular}

* While geothermal plants do not emit sulfur dioxide directly, once hydrogen sulfide is released as a gas into the atmosphere, it eventually changes into sulfur dioxide and sulfuric acid. Therefore, any sulfur dioxide emissions associated with geothermal energy derive from hydrogen sulfide emissions.

Hydrogen Sulfide $\left(\mathrm{H}_{2} \mathrm{~S}\right)$ (see $\mathrm{SO}_{2}$, above, for impacts and comparative information): Hydrogen sulfide is now routinely abated at geothermal power plants, resulting in the conversion of over 99.9 percent of the hydrogen sulfide from geothermal noncondensable gases into elemental sulfur, which can then be used as a non-hazardous soil amendment and fertilizer feedstock. Since 1976, hydrogen sulfide emissions have declined from $1,900 \mathrm{lbs} / \mathrm{hr}$ to $200 \mathrm{lbs} / \mathrm{hr}$ or less, although geothermal power production has increased from 500 megawatts (MW) to over 2,000 MW.

Mercury: Although mercury is not present in every geothermal resource, where it is present, mercury abatement equipment typically reduces emissions by 90 percent or more. The comparatively "highest" mercury emitters, two facilities at The Geysers in California, release mercury at levels that do not trigger any health risk analyses under strict California regulations.

\section{ADDITIONAL ENVIRONMENTAL ISSUES}

Noise Pollution: Normal geothermal power plant operation typically produces less noise than the equivalent produced "near leaves rustling from breeze," according to common sound level standards, and thus is not considered an issue of concern.

Water Use: Geothermal plants use 5 gallons of freshwater per megawatt hour, while binary air-cooled plants use no fresh water. This compares with 361 gallons per megawatt hour used by coal facilities. 
Water Quality: Geothermal fluids used for electricity are injected back into geothermal reservoirs using wells with thick casing to prevent cross-contamination of brines with groundwater systems. They are not released into surface waterways. At The Geysers facility, 11 million gallons of treated wastewater from Santa Rosa are pumped daily for injection into the geothermal reservoir. Injection reduces surface water pollution and increases geothermal reservoir resilience.

Land Use: Geothermal power plants can be designed to "blend-in" to their surrounding more so than fossil fired plants, and can be located on multiple-use lands that incorporate farming, skiing, and hunting. Over 30 years, the period of time commonly used to compare the life cycle impacts from different power sources, a geothermal facility uses 404 square meters of land per gigawatt hour, while a coal facility uses 3632 square meters per gigawatt hour.

-Subsidence: Subsidence, or the slow, downward sinking of land, may be linked to geothermal reservoir pressure decline. Injection technology, employed at all geothermal sites in the United States, is an effective mitigating technique.

-Induced Seismicity: While earthquake activity, or seismicity, is a natural phenomenon, geothermal production and injection operations have at times resulted in low-magnitude events known as "microearthquakes." These events typically cannot be detected by humans, and are often monitored voluntarily by geothermal companies.

Geysers, Fumaroles, and Geothermal Resources: While almost all geothermal resources currently developed for electricity production are located in the vicinity of natural geothermal surface features, much of the undeveloped geothermal resource base may be found deep under the Earth without any corresponding surface thermal manifestations. Geothermal surface features, while useful in identifying resource locations, are not used during geothermal development. U.S. laws and regulations protect and preserve national parks and their significant thermal features.

Impact on Wildlife and Vegetation: Before geothermal construction can begin, an environmental review may be required to categorize potential effects upon plants and animals. Power plants are designed to minimize the potential effect upon wildlife and vegetation, and they are constructed in accordance with a host of state and federal regulations that protect areas set for development. 


\section{Acknowledgements}

A number of people have helped to bring this project to fruition. First, we would like to thank our research advisory members: Liz Battocletti, Senior Associate, Bob Lawrence \& Associates, Inc.; Anna Carter, Principal, Geothermal Support Services; Roger Hill, Technical Director, GeoPowering the West, U.S. Department of Energy; Jeff Hulen, Senior Geologist, Energy and Geoscience Institute, University of Utah; Kevin Porter, Vice President, Exeter Associates Inc.; John Pritchett, Senior Scientist, Resource Technology Program, Science Applications International Corporation (SAIC); Joel Renner, Geothermal Program Manager, Renewable Energy and Power Technologies, Idaho National Engineering and Environmental Laboratory (INEEL); Ann RobertsonTait, Senior Geologist, GeothermEx, Inc.; Kathleen Rutherford, Senior Mediator, Resolve; and Charlene Wardlow, Manager of Development Permitting, Calpine Corporation. ${ }^{2}$ This group helped with every stage of development, from brainstorming topics to editing drafts. Charlene Wardlow provided essential guidance and countless hours of assistance for this project. Kevin Porter worked to get parts of the document published in specific journals, helped to tailor the pieces to those journals, and provided detailed feedback during various stages of the creation process. Dan Schochet, Vice President of Ormat, helped to edit the document and provide helpful information. Dennis Gilles, Vice President of Calpine, helped with information about The Geysers. Julia Watkins provided baseline data: Members of the Department of Energy, particularly Susan Norwood and Roy Mink, proved to be major assets. We thank the Department of Energy for funding this project. Thanks to the Geothermal Education Office (GEO) for providing many of the images shown throughout this document, and John Lund for providing a picture of the Blue Lagoon. Individuals who have offered their expertise and editorial skills include Laurie McClenehan, Mitch Stark, Brian Benn, Ted Clutter, Nathanael Hance, Gordon Bloomquist, Clifton Carwile, Christina Mudd, Kit Bloomfield, and Frank Monastero. Finally, we thank the following people, among others previously mentioned, for providing final edits and information during public review of the document: Doug B. Jung, Carol Werner, Fred Beck, Richard Price, Jeff Adams, Andy Johnson, Bruce Green, Amanda Ormond, Marcello Lippmann, Lisa Shevenell, Jon Wellinghoff, Marilyn Nemzer, Chuck Kutscher, Thomas Petersik, and Bob Neilson.

\footnotetext{
${ }^{2}$ Research advisory members' affiliated companies listed for identification purposes only
} 
Table of Contents

List of Tables ...................................................................................................................... vii

List of Figures .................................................................................................... vii

List of Myths.............................................................................................................. viii

Acronyms and Abbreviations .......................................................................................... ix

Introduction and Background ..................................................................................... 10

I. Introduction ......................................................................................................... 1

Geothermal Myths Explained ....................................................................................... 2

Myth 1: Geothermal Energy is Experimental and Not Yet Widely Used...................... 4

II. Converting Geothermal Energy into Electricity............................................................. 4

III. Geothermal Plants and Cooling Systems....................................................................... 5

IV. Reliability of Geothermal Power Generation ..................................................................... 7

V. Percentage of Domestic Geothermal Power Production............................................... 9

Myth 2: Geothermal Resources are Nonrenewable................................................ 14

VI. Managing Geothermal Systems................................................................................ 14

VII. Geothermal Potential ................................................................................................ 15

Geothermal Energy and the Environment ............................................................... 20

VIII. Applicable Environmental Regulations - An Overview........................................ 20

Clean Air Act Regulations ........................................................................................... 20

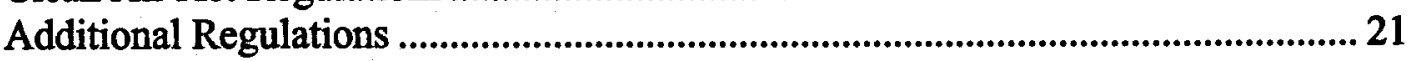

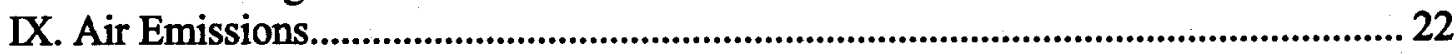

Myth 3: Geothermal Power Plants Emit Smoke .......................................................... 25

Nitrogen Oxides ........................................................................................................... 25

Hydrogen Sulfide ........................................................................................................... 27

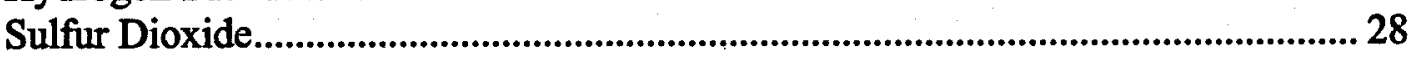

Particulate Matter.................................................................................................... 30

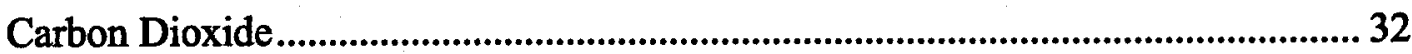

Mercury ................................................................................................................ 34

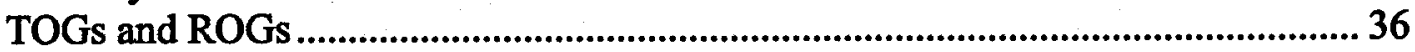

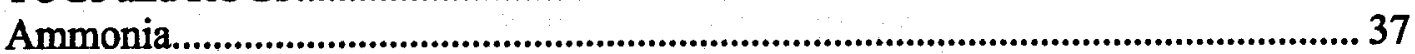

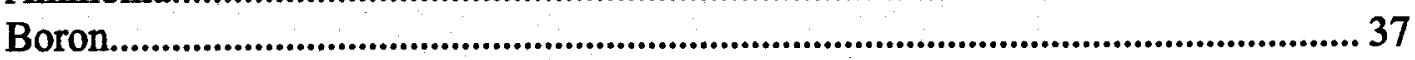

Air Emissions: Concluding Overview ............................................................... 38

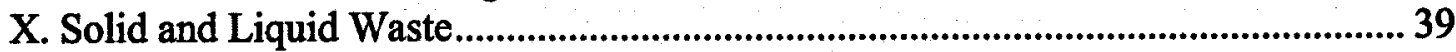

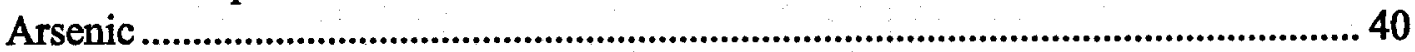

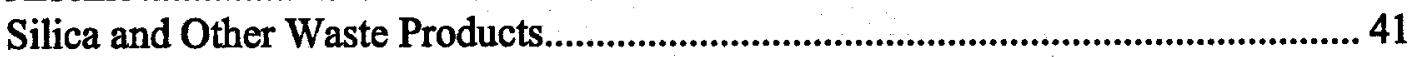

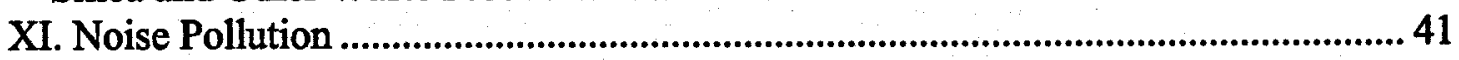

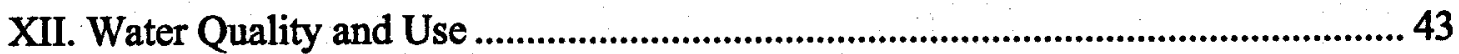

Injection of Geothermal Fluids ....................................................................................... 44

Wastewater Injection: Success at The Geysers.............................................................45

Myth 4: Extraction Injection of Geothermal Brines Contaminates Drinking Water.46

XIII. Land Use ............................................................................................................. 48

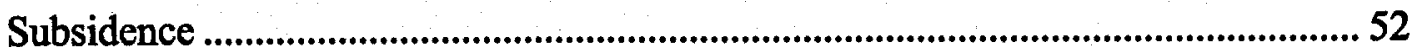

Induced Seismicity ........................................................................................................... 54

Seismic Monitoring .......................................................................................................... 55 


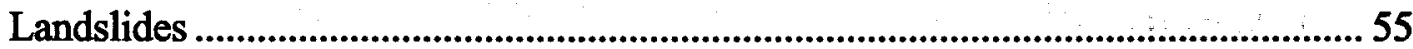

XIV. Geysers, Fumaroles, and Geothermal Resources................................................. 56

Myth 5: Natural Geothermal Surface Features Are Used During Geothermal

Development. ...............................................................................................57

Myth 6: Current Geothermal Development Alters Geothermal Land Features....... 58

XV. Impact on Wildlife and Vegetation....................................................................5 58

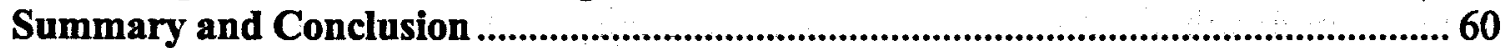

XVI. The Big Picture: Electricity Production and its Consequences ..............................6 60

XVII. Summarized Environmental Benefits of Geothermal Energy ............................... 61

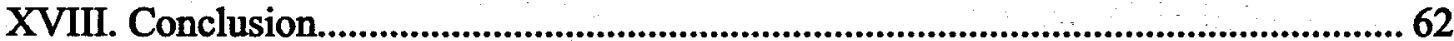

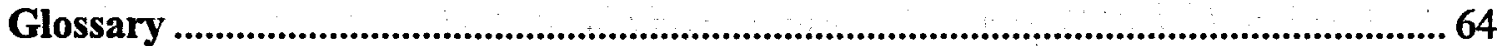

Index 


\section{List of Tables}

Table 1: Capacity Factor, Selected Renewable Technologies......................................8

Table 2: Plant by Plant Comparison ......................................................................... 24

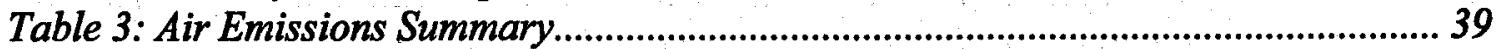

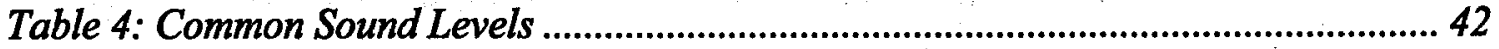

\section{List of Figures}

Figure 1: Earth's Temperatures ............................................................................... 3

Figure 2: Flash and Dry Steam Power Plant Diagrams ................................................ 5

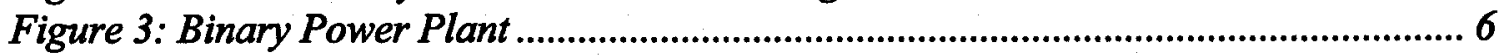

Figure 4: Geothermal Power Plant with Water Cooling System .................................... 7

Figure 5: Total United States Energy Use, 2003...................................................... 10

Figure 6: United States Electricity Use, 2003 .......................................................... 11

Figure 7: United States Renewable Electricity Use, 2003 .......................................... 12

Figure 8: California Renewable Electricity Use, 2003 .............................................. 13

Figure 9: Estimated Subterranean Temperatures at 3 Kilometers Depth........................ 17

Figure 10: Estimated Subterranean Temperatures at 6 Kilometers Depth..................... 17

Figure 11: U.S. Geothermal Potential....................................................................... 19

Figure 12: World Geothermal Potential..................................................................... 19

Figure 13: Life Cycle versus Operational Emissions, Coal Power Plants...................... 23

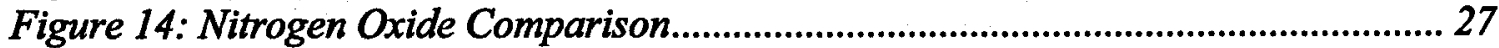

Figure 15: Sulfur Dioxide Comparison .......................................................................... 30

Figure 16: Particulate Matter Comparison.............................................................. 31

Figure 17: Carbon Dioxide Comparison...................................................................... 34

Figure 18: Blue Lagoon: Tourist Attraction and Geothermal "Wastewater".................. 45

Figure 19: Freshwater Use Comparison.................................................................... 48

Figure 20: Puna Flash/Binary Geothermal Plant ....................................................... 49

Figure 21: Imperial Valley Power Plant Next to Productive Farmland ......................... 50

Figure 22: 30 Year Land Use ................................................................................ 51

Figure 23: Geothermal Surface Features.............................................................. 56 


\section{List of Myths}

Myth 1: Geothermal Energy is Experimental and Not Yet Widely Used.......................... 4

Myth 2: Geothermal Resources are Nonrenewable ......................................................... 14

Myth 3: Geothermal Power Plants Emit Smoke ............................................................ 25

Myth 4: Extraction and Injection of Geothermal Brines Contaminates Drinking Water. 46

Myth 5: Natural Geothermal Surface Features Are Used During Geothermal

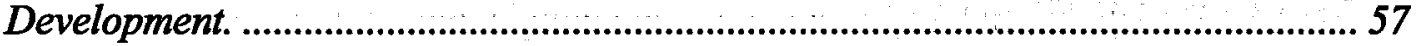

Myth 6: Current Geothermal Development Alters Geothermal Land Features............... 58 


\section{Acronyms and Abbreviations}

BLM United States Bureau of Land Management

CAA Clean Air Act

CARB California Air Resources Board

dBA units of decibels A-weighted

DOE United States Department of Energy

DOI United States Department of Interior

EA Environmental Assessment

EERE Energy Efficiency and Renewable Energy (of U.S. Department of Energy)

EIR Environmental Impact Report

EIS Environmental Impact Statement

EPA United States Environmental Protection Agency

EPRI Electric Power Research Institute

GAMP Geysers Air Monitoring Program

GEA Geothermal Energy Association

GRC Geothermal Resources Council

INEEL Idaho Engineering and Environmental Laboratory

LRMP Land and Resource Management Plan

MERP Denver Metro Emission Reduction Plan

NAAQS National Ambient Air Quality Standards

NEPA National Environmental Policy Act

NESHAP National Emission Standards for Hazardous Air Pollutants

ng nanogram

NOx Nitrogen Oxide

NREL National Renewable Energy Laboratory

NSPS new source performance standards

PM Particulate Matter

$\mathrm{ppb} \quad$ parts per billion

RCRA Resource Conservation and Recovery Act 
ROG Reactive Organic Gas

RPM Risk Management Program

SIP State Implementation Plan

SMAC Seismic Monitoring Committee

SOx Sulfur Oxide

TOG Total Organic Gases

UURI University of Utah Research Institute

UCS Union of Concerned Scientists

USGS United States Geological Survey

VOC Volatile Organic Compound

WGC World Geothermal Conference 


\section{Introduction and Background}

\section{Introduction}

In May 2004, the Geothermal Energy Association (GEA) completed an extensive literature review of the environmental, socio-economic and technological information publicly available about geothermal energy. This review was conducted in response to concerns that there was a lack of accurate, up-to-date information about this renewable energy source. That assessment found that the available literature was seriously inadequate, often providing outdated or false information. For those interested in this review, GEA published its assessment of the available literature concerning environmental issues of geothermal energy, ${ }^{3}$ including air emissions, land use, water quality, and noise pollution. It is available on the GEA web site (www.geo-energy.org) or by request.

The purpose of this paper, therefore, is to provide accurate and current information about the environmental aspects of geothermal energy, particularly as they relate to high temperature grade, electricity producing geothermal plants. The two other forms of geothermal technology, direct use and heat pumps, will not be discussed at length in this paper. While technical and referenced, this paper is meant to be accessible to a wide audience, including interested individuals and policy makers. The paper focuses upon U.S. domestic geothermal environmental concerns and benefits; however, much of the information presented applies to worldwide geothermal development as well.

\footnotetext{
${ }^{3}$ Gawell, Karl and Diana Bates (May 2004). Geothermal Literature Assessment: Environmental Issues. Geothermal Energy Association (GEA): Washington, D.C.
} 


\section{Geothermal Myths Explained}

In common parlance, a myth is a fiction - something which is untrue. An invented truth takes on the proportion of being a myth when it is repeated often enough to take on a life of its own, to appear to have meaning in its own right.

Today, geothermal developers face many obstacles, and one of them is inadequate public understanding of geology, hydrology, and the related sciences that underlie geothermal energy. A recent publication for the National Geothermal Collaborative ${ }^{4}$ found that widespread misconceptions about geothermal energy posed major barriers to its use. We have, therefore, tried to address some the most common myths about geothermal energy in text boxes throughout this document.

Geothermal energy is defined as heat from the Earth. It is a clean, renewable resource that provides energy in the United States and around the world. It is considered a renewable energy resource because the heat emanating from the interior of the Earth is essentially limitless. The heat continuously flowing from the Earth's interior is estimated to be equivalent to 42 million megawatts of power. ${ }^{3}$ One megawatt is equivalent to 1 million watts, and can meet the power needs of about 1,000 people.

The interior of the Earth is expected to remain extremely hot for billions of year to come, ensuring an essentially limitless flow of heat. Geothermal power plants capture this heat and convert it to energy in the form of electricity. The picture below shows the source of geothermal electric power production, heat from the Earth. As depth into the Earth's crust increases, temperature increases as well.

\footnotetext{
${ }^{4}$ McClenahan, Laurie, et al (Jan 2005). Geothermal Outreach Principles and Comment Analysis Report. Prepared for National Geothermal Collaborative (NGC). Retrieved April 6, 2005, from http://www.geocollaborative.org/publications/Geothermal Outreach Principles Report.pdf. ${ }^{5}$ Energy and Geosciences Institute, University of Utah. Prepared by the U.S. Geothermal Industry for the Renewable Energy Task Force (1997), Briefing on Geothermal Energy. Washington, D.C.
} 
Figure 1: Earth's Temperatures

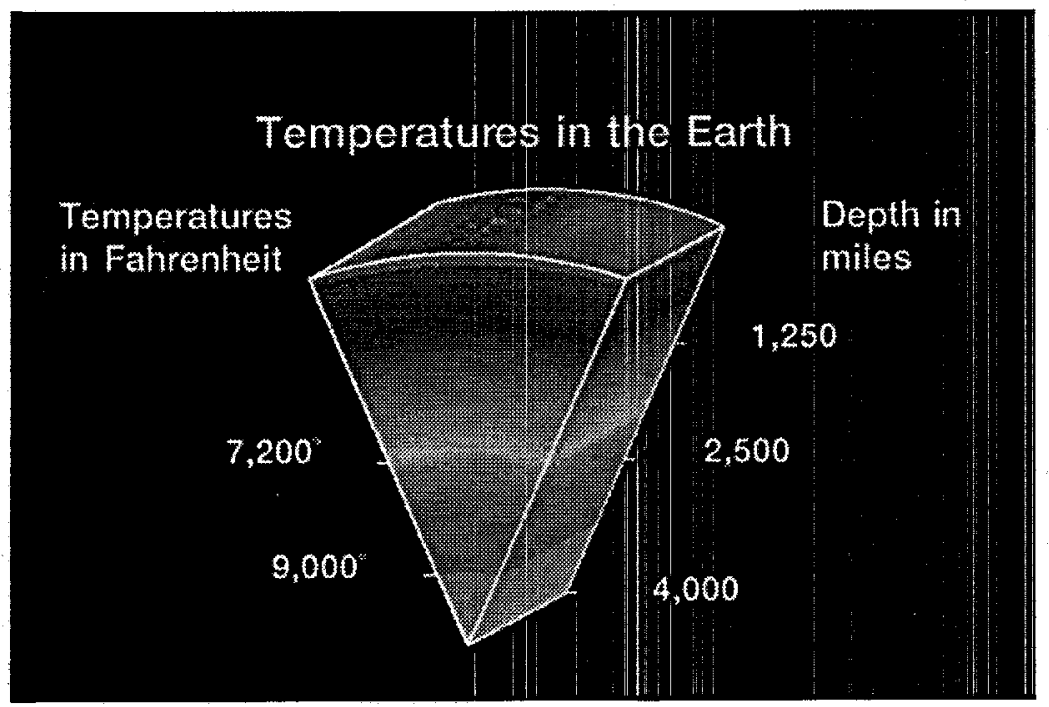

Source: Geothermal Education Office

Like all forms of electric generation, both renewable and non-renewable, geothermal power generation has environmental impacts and benefits. By comparison to other forms of electricity generation, this paper highlights the benefits of choosing geothermal energy over other sources. Topics discussed include air emissions, noise pollution, water usage, land usage, waste disposal, subsidence, induced seismicity, and impacts on wildlife and vegetation. In addition, common environmental myths associated with geothermal energy are addressed throughout the paper. Geothermal energy - whether utilized in a binary, steam, or flash power plant, cooled by air or water systems - is a clean, reliable source of electricity with only minimal environmental impacts, even when compared with other renewable energy sources.

Wherever comparisons with other energy technologies are used, they are intended to provide a context for the reader. Every effort has been made to use comparable data from companies, industry groups, and government agencies. In providing these comparisons, we recognize that energy technologies have many different attributes, all of which should be considered. 


\section{Myth 1: Geothermal Energy is Experimental and Not Yet Widely Used}

Truth: Geothermal resources have been in use in the United States for more than 10,000 years, according to archaeological evidence. The Paleo-Indians first used geothermal hot springs for warmth, cleansing, and minerals through direct use. ${ }^{6}$ The first large-scale geothermal electricity-generating plant opened at Larderello, Italy in 1904, and continues to operate successfully. ${ }^{7}$ The first commercial U.S. geothermal power plant producing power to the utility grid opened at The Geysers in California in 1960, producing 11 megawatts of net power. The Geysers system continues to operate successfully today, and represents the largest single sources of renewable energy in the world. The United States has nearly 2800 megawatts of electricity connected to the grid. ${ }^{8}$ As the world's largest producer of geothermal energy, The U.S. generates a yearly average of 15 billion kilowatt hours of power, comparable to burning about 25 million barrels of oil or 6 million short tons of coal per year. ${ }^{9}$ Geothermal energy is used for electrical power production in 21 countries, and supplies significant amounts of electricity to countries such as the Philippines, where 27 percent of electricity derives from geothermal sources. ${ }^{10}$ Even so, this worldwide use represents only a fraction of the potential power that could be generated from geothermal resources. As technology continues to advance, the expected cost and risk of using geothermal resources will continue to decline while the geothermal contribution to our energy needs will continue to expand.

\section{Converting Geothermal Energy into Electricity}

Heat emanating from the Earth's interior and crust generates magma (molten rock). Because magma is less dense than surrounding rock, it rises but generally does not reach the surface, heating the water contained in rock pores and fractures. Wells are drilled into this natural collection of hot water or steam, called a geothermal reservoir, in order to bring it to the surface and use it for electricity production. ${ }^{11}$ The three basic types of geothermal electrical generation facilities are binary, dry steam (referred to as "steam"), and flash steam (referred to as "flash"). Electricity production from each type depends on reservoir temperatures and pressures, and each type produces somewhat different

\footnotetext{
${ }^{6}$ U.S. DOE, Energy Efficiency and Renewable Energy [EERE]. Geothermal Technologies Program. (2003). A History of Geothermal Energy in the United States. Retrieved November 1, 2004, from http://www.eere.energy.gov/geothermal/history.html

${ }_{7}^{7}$ U.S. DOE, EERE. Geothermal Technologies Program. (2004). Geothermal Power Plants.

Retrieved December 6, 2004, from http://www.eere.energy.gov/geothermal/powerplants.html

${ }^{8}$ Gawell, et al (1999). Geothermal Energy: the Potential for Clean Power from the Earth. Geothermal Energy Association, Washington, DC.

${ }^{9}$ Using Energy Information Administration (EIA) average geothermal energy production, 1990 - 2003, and EIA conversion information

${ }^{10}$ The World Bank Group (2002). Geothermal Energy. Retrieved December 6, 2004, from http://www.worldbank.org/html/fpd/energy/geothermal/

${ }^{11}$ GEO
} 
environmental impacts. In addition, the choice of using water or air cooling technology in the power plants has economic and environmental trade-offs.

\section{Geothermal Plants and Cooling Systems}

The most common type of power plant to date is a flash power plant with a water cooling system, where a mixture of water and steam is produced from the wells. The steam is separated in a surface vessel (steam separator) and delivered to the turbine, and the turbine powers a generator.

In a dry steam plant like those at The Geysers in California, steam directly from the geothermal reservoir runs the turbines that power the generator, and no separation is necessary because wells only produce steam. Figure 2 shows a flash and dry steam plant.

Figure 2: Flash and Dry Steam Power Plant Diagrams

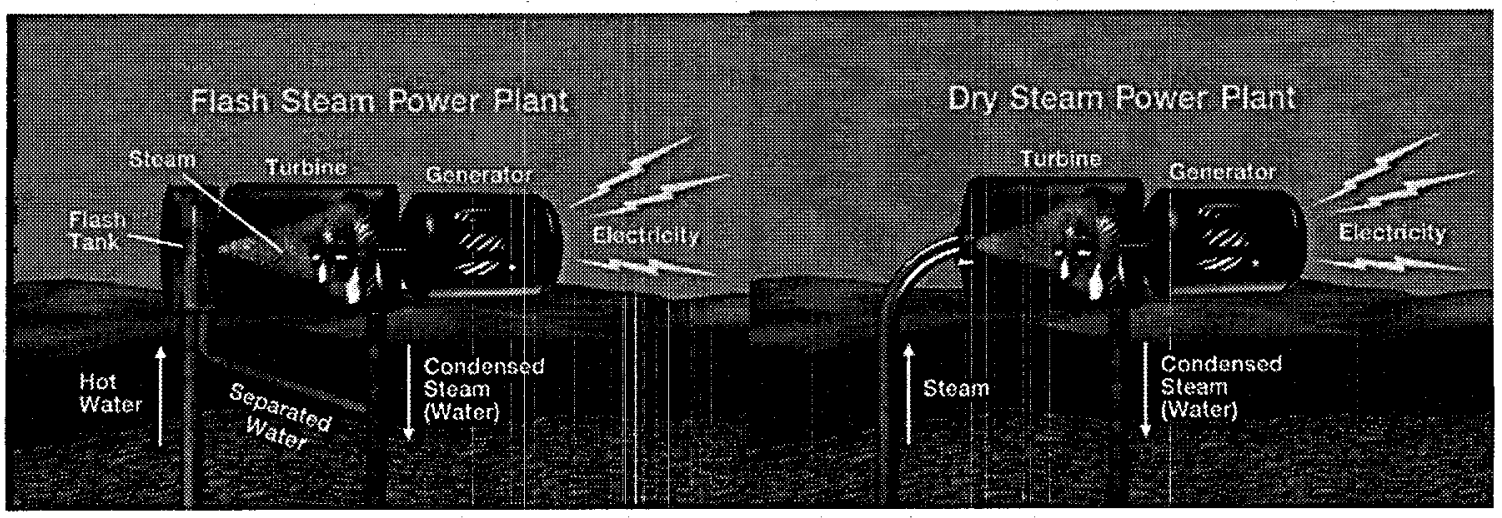

Source: Geothermal Education Office (GEO)

Recent advances in geothermal technology have made possible the economic production of electricity from lower temperature geothermal resources, at $100^{\circ} \mathrm{C}\left(212^{\circ} \mathrm{F}\right)$ to $150^{\circ} \mathrm{C}$ $\left(302^{\circ} \mathrm{F}\right)$. Known as "binary" geothermal plants, these facilities reduce geothermal energy's already low emission rate to near zero.

In the binary process, the geothermal water heats another liquid, such as isobutane, that boils at a lower temperature than water. The two liquids are kept completely separate through the use of a heat exchanger used to transfer the heat energy from the geothermal water to the "working-fluid." The secondary fluid vaporizes into gaseous vapor and (like steam) the force of the expanding vapor turns the turbines that power the generators. If the power plant uses air cooling (see next paragraph) the geothermal fluids never make contact with the atmosphere before they are pumped back into the underground 
geothermal reservoir, effectively making the plant emission free. Developed in the $1980 \mathrm{~s}$, this technology is already in use in geothermal power plants throughout the world in areas that have lower resource temperatures. The ability to use lower temperature resources increases the number of geothermal reservoirs that can be used for power production. Figure 3 shows a binary power plant.

Figure 3: Binary Power Plant

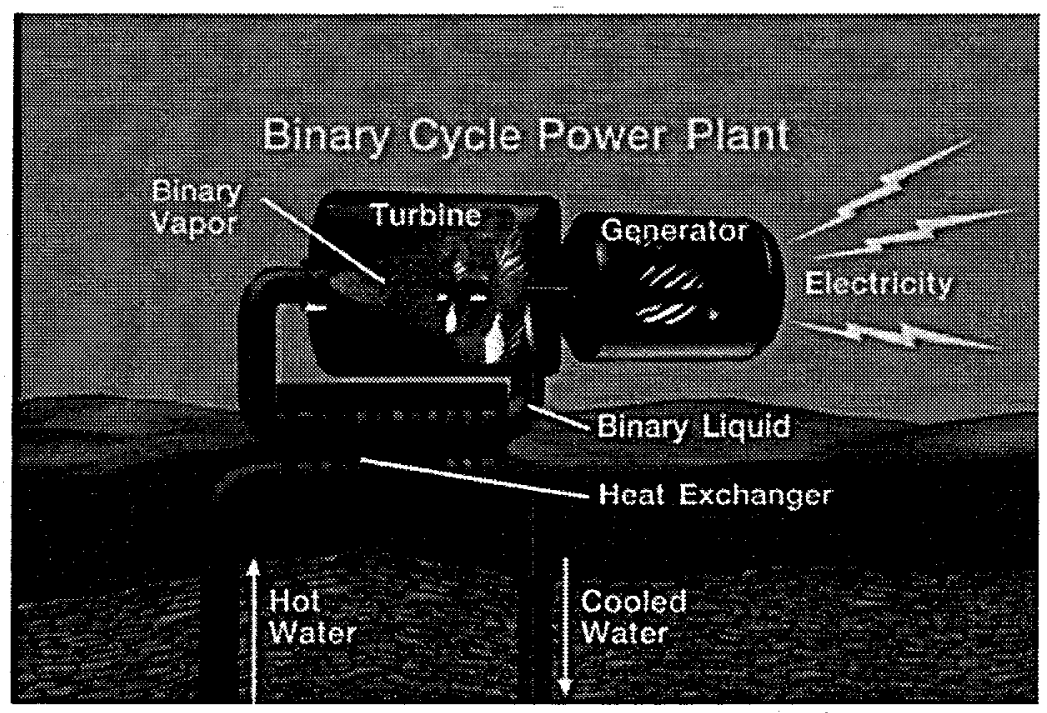

Source: Geothermal Education Office

A cooling system is essential for the operation of any modern geothermal power plant. Cooling towers prevent turbines from overheating and prolong facility life. Most power plants, including most geothermal plants, use water cooling systems. Figure 4 below shows a more complex diagram of a geothermal power plant, complete with a water (evaporative) cooling system. Figures 2 and 3 simplify the process of electricity production, while figure 4 shows greater detail and accuracy. Water cooled systems generally require less land than air cooled systems, and are considered overall to be effective and efficient cooling systems. The evaporative cooling used in water cooled systems, however, requires a continuous supply of cooling water and creates vapor plumes. Usually, some of the spent steam from the turbine (for flash- and steam-type plants) can be condensed for this purpose. Air cooled systems, in contrast to the relative stability of water cooled systems, can be extremely efficient in the winter months, but are less efficient in hotter seasons when the contrast between air and water temperature is reduced, so that air does not effectively cool the organic fluid. Air cooled systems are beneficial in areas where extremely low emissions are desired, or in arid regions where water resources are limited, since no fluid needs to be evaporated for the cooling process. Air cooled systems are preferred in areas where the viewshed is particularly sensitive to the effects of vapor plumes, as vapor plumes are only emitted into the air by wet cooling 
towers and not air cooling towers. Most geothermal air cooling is used in binary facilities.

Figure 4: Geothermal Power Plant with Water Cooling System

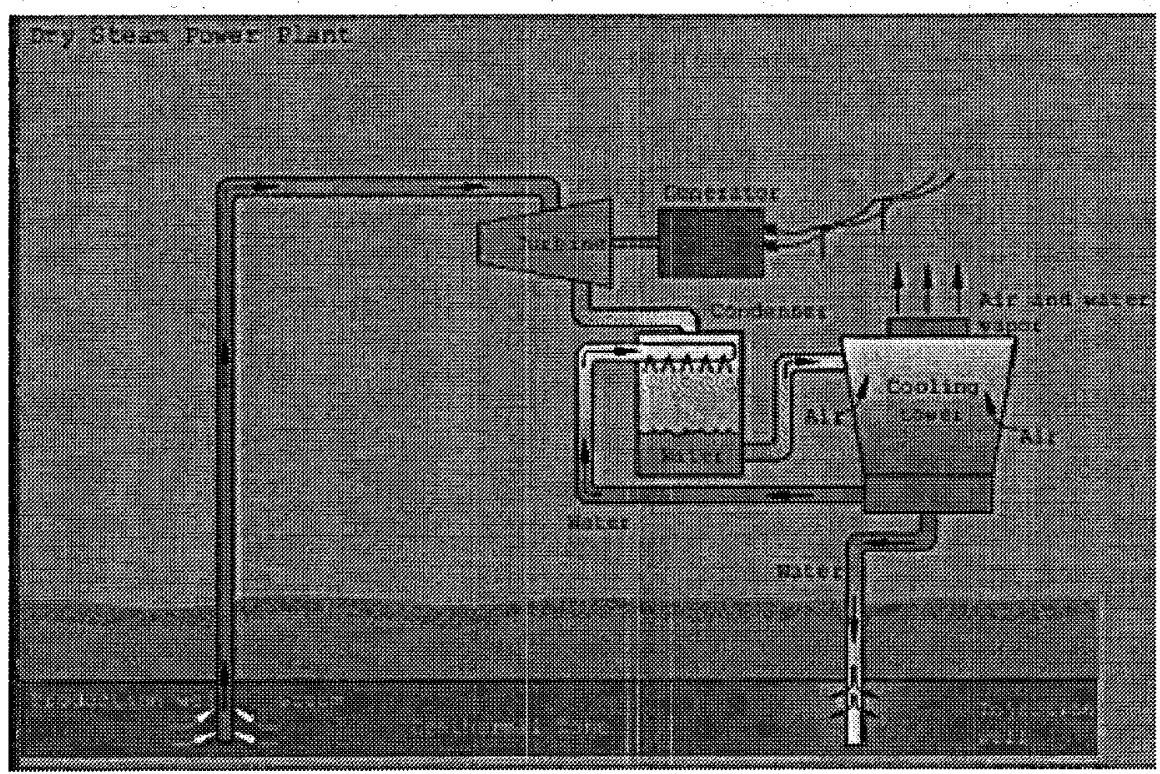

Source: Idaho National Engineering and Environmental Lab (INEEL)

A combination of flash and binary technology, known as the flash/binary combined cycle, has been used effectively to take advantage of the benefits of both technologies. In this type of plant, the flashed steam is first converted to electricity with a backpressure steam turbine, and the low-pressure steam exiting the backpressure turbine is condensed in a binary system. This allows for the effective use of air cooling towers with flash applications and takes advantage of the binary process. The flash/binary system has a higher efficiency where the well-field produces high pressure steam, while the elimination of vacuum pumping of noncondensable gases allows for 100 percent injection. This type of system has been operating in Hawaii since 1991 at the Puna Geo Venture facility (see Figure 20), where the geothermal fluid is over $600^{\circ} \mathrm{F}$. It is also being used in three power projects in New Zealand, and in the Philippines since 1995 at the Upper Mahiao geothermal facility.

\section{Reliability of Geothermal Power Generation}

The source of geothermal energy, the Earth's heat, is available 24 hours a day, 365 days a year. Solar and wind energy sources, in contrast, are dependent upon a number of factors, including daily and seasonal fluctuations and weather variations. For these reasons, electricity from geothermal energy is more consistently available, once the resource is 
tapped, than many other forms of electricity. Geothermal plants characteristically have very low planned and unplanned outage rates (times when power is in demand but unavailable due to a forced outage). Geothermal power's availability, measured as the number of hours that a power plant is available to produce power divided by the total hours in a set time period, usually a year, is about 95 percent. This means that geothermal electric-power plants are available for generation 95 percent of any given time, based on decades of observations by plant operators. ${ }^{12}$

While availability factor measures a plant's potential for use, capacity factor measures the amount of real time during which a facility is used, and is therefore less than or equal to a plant's availability factor. To understand availability and capacity factor, consider the analogy of a working car. When a car is not in use, but is free from defects and available to be used, we may speak of the car's availability factor. When the car is actually being driven, we may speak of the car's capacity factor.

Capacity factor can be influenced by changes in the resources, equipment or transmission variability, power market fluctuations and other factors. For example, a facility may not be able to produce at fully rated capacity because the resource is constrained -- a well might become clogged, subsurface conditions might change, or water might not be available in sufficient quantities to support the same level of resource production. Equipment or transmission problems can negatively influence the capacity factor even if the resource itself is available. Also, in recent years, capacity factors are being affected by the power market. While in the past geothermal facilities were almost always operated as baseload plants, running at a nearly constant output 24-hours a day, in recent years a significant portion of U.S. geothermal facilities are being operated as merchant power plants and may not have customers all of the time. But, despite all of these factors, geothermal facilities retain high capacity factors. The table below provides national capacity factor information for four renewable energy sources. ${ }^{13}$

Table 1: Capacity Factor, Selected Renewable Technologies

\begin{tabular}{|l|l|}
\hline Technology & Capacity Factor, Percentage Range \\
\hline Geothermal & $89-97$ \\
\hline Biomass* & 80 \\
\hline Wind & $26-40$ \\
\hline Solar** & $22.5-32.2$ \\
\hline
\end{tabular}

* Biomass represented as average Direct-Fired Biomass facility

** Solar represented as average Utility-Scale PV Concentrator

${ }^{12}$ U.S. DOE. Energy and Geosciences Institute at University of Utah, (May 2001). Geothermal Energy: Clean Sustainable Energy for the Benefit of Humanity and the Environment. [Brochure]. Retrieved October 15, 2004, from http://www.geo-energy.org/RedBrochure.pdf.

${ }^{13}$ Source: U.S. DOE, EERE (Dec 97). Renewable Energy Technology Characterizations. (EPRI Topical Report No. TR-109496). Retrieved March 4, 2005, from http://www.eere.energy.gov/consumerinfo/tech reports.html. 
Because some renewable energy sources do not offer the reliability attained from fossil fuel sources, they are often discounted in discussions of the looming large-scale power needs of the twenty-first century. Geothermal, however, has the potential to provide reliable sources of electricity comparable to baseload coal or nuclear power sources, while still offering significantly lower emissions levels than fossil fuel sources and avoiding problems of radioactive waste disposal posed by nuclear sources.

\section{V.Percentage of Domestic Geothermal Power Production}

Figures 5 through 8 display a variety of ways to compare geothermal energy and other energy sources. Figure 5 shows United States energy use from all sectors, including the electricity, transportation, and industrial sectors, and also highlights total sources of domestic renewable energy. ${ }^{14}$ Figure 6 shows United States energy use in the electricity sector only, ${ }^{15}$ a useful comparison considering geothermal is predominantly used to generate electricity. Figure 7 breaks down the renewable electricity use shown in Figure 6 into the five sources of renewable energy available for electricity production in the United States. ${ }^{16}$ Finally, Figure 8 shows renewable electricity production in California, ${ }^{17}$ the state that boasts the largest geothermal electricity production in the United States and, consequently, in the world.

\footnotetext{
${ }^{14}$ U.S. DOE. Energy Information Administration. Renewable Energy Trends. Retrieved September 28, 2004, from http://www.eia.doe.gov/cneaf/solar.renewables/page/trends/figl.html.

${ }^{15}$ U.S. DOE. Energy Information Administration. Renewable Energy Consumption. Retrieved February 11, 2005 from http://www.eia.doe.gov/cneaf/solar.renewables/page/trends/table3.html.

${ }^{16}$ U.S. DOE. Energy Information Administration. Country Analysis Brief: America. Retrieved February 14, 2005. from http://www.eia.doe.gov/emeu/cabs/usa.html.

${ }^{17}$ Source: California Energy Commission (CEC) (2003). California Gross System Power for 2003 In Gigawatt-Hours (GWh). Retrieved November 16, 2004, from http://www.energy.ca.gov/electricity/gross system power.html
} 
In 2003, geothermal was the third largest source of renewable energy. Geothermal provided 0.3 percent of total national energy production, and accounted for 5 percent of total annual renewable energy production, or 5 percent of the 6 percent total for renewable production. Most renewable energy used in the U.S. today is from biomass, including municipal solid waste, and hydroelectric power, and this trend continues when considering overall energy use (Figure 5) as well as electricity use specifically (Figure 6). Note the significant contribution of petroleum to total domestic energy use in Figure 5 Petroleum is used predominantly for motor gasoline consumption (at 44 percent of total petroleum consumption), and secondarily for distillate fuel oil consumption ( 20 percent), a type of petroleum used for space heating, diesel engine fuel and electric power generation.

Figure 5: Total United States Energy Use, 2003

Total = 98.006 Quadrillion Btu

Total = 6.131 Quadrillion Btu

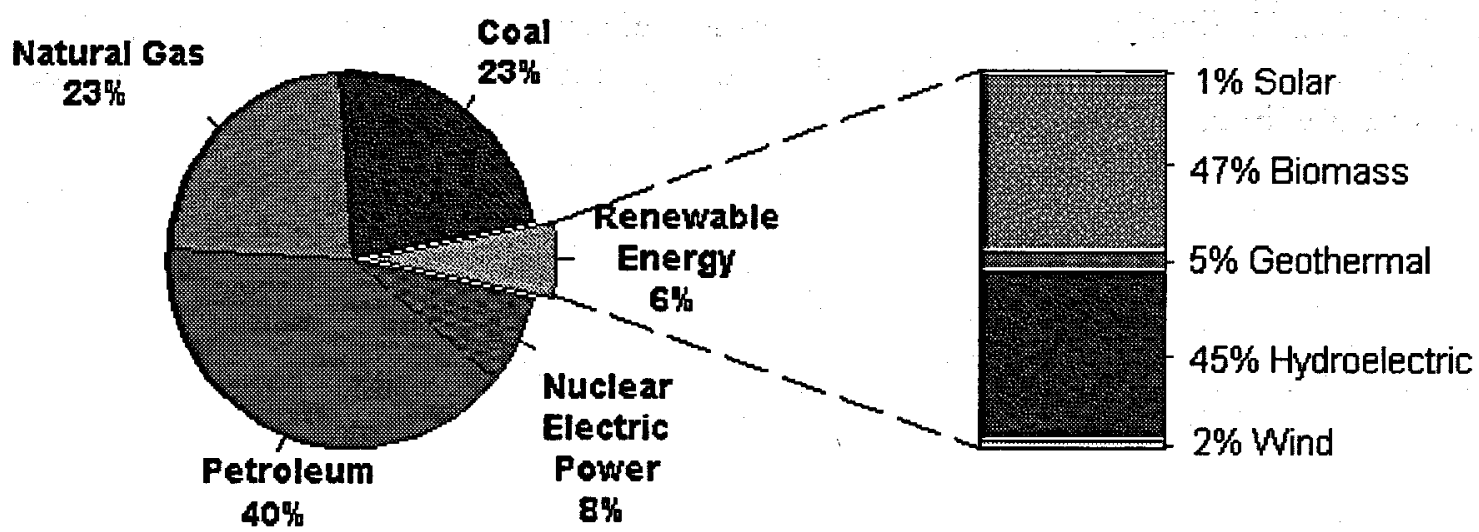


Figure 6 displays domestic electricity use. Note that while "geothermal and other" account for 1 percent of electricity use, coal facilities account for over half of electricity use in the United States.

Figure 6: United States Electricity Use, 2003

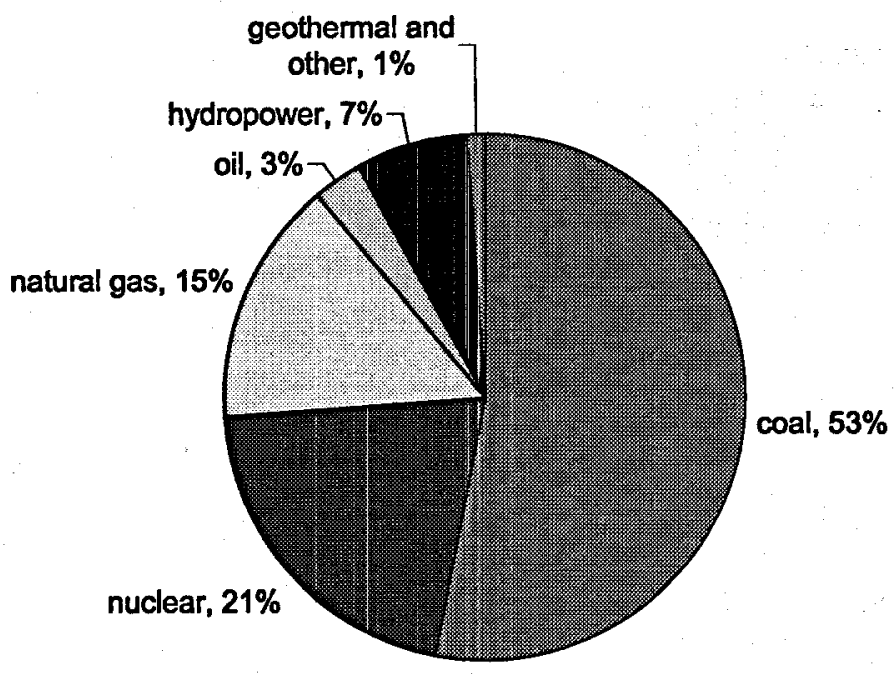


Figure 7 illustrates the renewable energy contribution by individual renewable energy technologies to electrical power production. As with energy, geothermal is the third largest source of renewable electricity after hydro and biomass.

Figure 7: United States Renewable Electricity Use, 2003

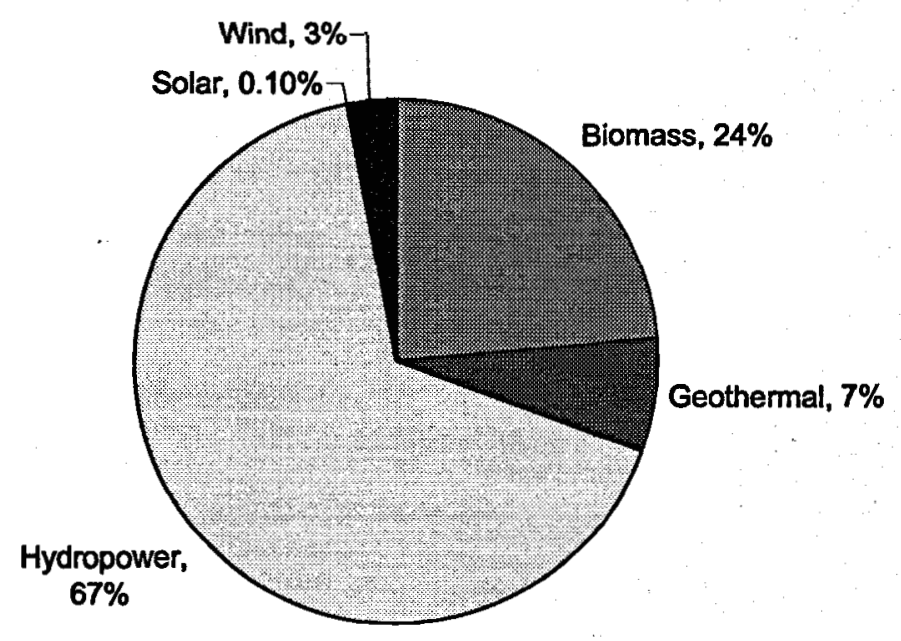

* Percentages may not add up to 100 percent due to independent rounding

The availability of renewable resources in the U.S. varies significantly by region. In areas where geothermal resources are available, such as California, the percentage of electricity derived from geothermal sources can exceed 7 times the national electricity average. Most geothermal production is concentrated in the western states.

In California, the state with the largest amount of geothermal power on-line, electricity from geothermal resources accounted for 5 percent of the state's electricity generation in 2003 on a per kilowatt hour basis. ${ }^{18}$ California has an installed capacity of $2478 \mathrm{MW}$ of geothermal power plants. ${ }^{19}$ Geothermal is the largest non-hydro renewable energy source in the state, nearly equaling the combined total of all other renewable sources of electricity, excluding large scale hydro. Note that the California Energy Commission (CEC) does not consider large hydroelectric projects in their renewable analysis, so this

\footnotetext{
${ }^{18}$ California Energy Commission (2002). Overview of Geothermal Energy in California. Retrieved November 8, 2004. from, http://www.energy.ca.gov/geothermal/overview.html.

${ }^{19}$ California Energy Commission. (July 2004). California Power Plants Database. Retrieved March 15, 2005, from http://www.energy.ca.gov/database/index.html/powerplants.
} 


$$
\text { Bum }
$$

data was omitted from Figure 8. However, large-scale hydro projects account for approximately 16 percent of total electricity use in California, according to the CEC. In addition to California, other regions with particularly high geothermal usage include Nevada and Hawaii. Geothermal energy provides about 9 percent of northern Nevada's electricity, ${ }^{20}$ and about 25 percent of the island of Hawaii's electricity. ${ }^{21}$

Figure 8: California Renewable Electricity Use, 2003

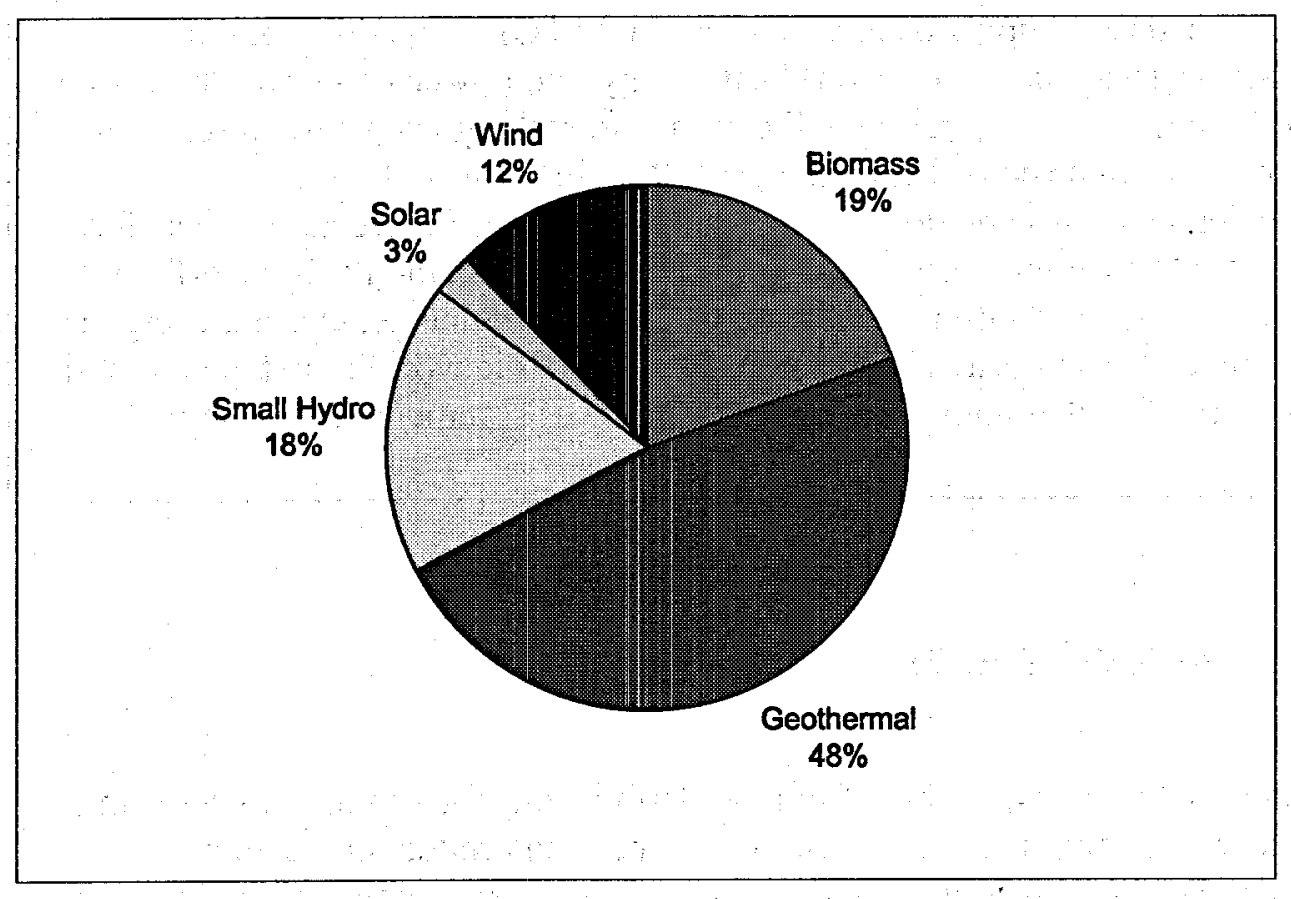

${ }^{20}$ U.S. DOE. NREL (Oct 2001). Geothermal Energy: Heat from the Earth, Nevada (Publication No. DOE/GO -102001-1432). Retrieved December 6, 2004, from http://www.nrel.gov/docs/fy02osti/29214.pdf. ${ }^{21}$ U.S DOE. Geothermal Technologies Program (Dec 2004) Geopowering the West: Hawaii Facts Sheet. Retrieved December 21, 2004, from http://www.eere.energy.gov/geothermal/gpw hawaii.html. 


\section{Myth 2: Geothermal Resources are Nonrenewable}

Truth: Geothermal resources are, by both legal classification and scientific definition, renewable. The word "geothermal" comes from the Latin roots, "geo," defined as "Earth," and "thermal," defined as "heat." Geothermal energy is literally heat from the Earth, and the Earth's heat is essentially limitless. As far as today's science can determine, the center of the Earth has been very, very hot for some 3.9 billion years and will continue to be hot for at least that far into the future. At the Earth's core, 4,000 miles deep, temperatures can reach upwards of $9,000^{\circ} \mathrm{F}\left(5,000^{\circ} \mathrm{C}\right) .^{22}$ In addition, the underground water or steam used to convert heat energy into power will never diminish if managed properly, because precipitation will continue to recharge geothermal reservoirs. Geothermal resources can be considered renewable "on timescales of technological/societal systems and do not need geological times for regeneration as fossil fuel reserves do."23 The National Energy Policy Act of 1992 and the Pacific Northwest Electric Power Planning and Conservation Act of 1980 both define geothermal energy as a renewable resource. ${ }^{24}$ The Larderello field in Italy, site of the world's first geothermal power plant, is currently celebrating its $100^{\text {th }}$ anniversary of commercial electricity production.

\section{Managing Geothermal Systems}

In existing geothermal systems, the heat from the Earth is transformed into power using underground water or steam. In some cases, there have been production declines at geothermal fields. Declines may be caused by wellfield problems with scaling, by a loss of water/steam, or by declining temperatures in specific areas or wells. With a geothermal resource, heat may continue to be available indefinitely, but the carrier medium (water) and reservoir must be properly managed. Managing the fluids used to generate power is an important part of developing a sustainable geothermal energy plant.

The carrier medium, either water or, at higher temperatures, steam, is stored in what is known as a geothermal reservoir. A geothermal reservoir is the entire system of fractured and permeable rocks, along with the hot water or steam circulating in that volume of rock. ${ }^{25}$ The success of a geothermal power plant depends upon how efficiently the geothermal reservoir is managed, regardless of the temperature or type of resource itself.

\footnotetext{
${ }^{22}$ Geothermal Education Office (2000). Geothermal Energy Facts. Retrieved December 21, 2004, from http://geothermal.marin.org/pwrheat.html.

${ }^{23}$ Rybach et al (1999): How Renewable Are Geothermal Resources? Geothermal Resources Council [GRC] Transactions, Vol. 23, Oct 17-20, 563-566.

${ }^{24}$ Northwest Power and Conservation Council (2004). Pacific Northwest Electric Power Planning and Conservation Act. Retrieved September 18, 2004, from $\mathrm{http}: / / \mathrm{www} . n$ wcouncil.org/library/poweract/default.htm

${ }^{25}$ U.S. DOE. NREL (March 1998). Reservoir Engineering. (DOE/GO-10098-535). Retrieved February 1, 2005 from http://www.eere.energy.gov/geothermal/pdfs/reservoir.pdf.
} 
For example, significant pressure declines occurred during the 1980's at The Geysers steamfield in California, where about 75 percent of the water condensed from the produced geothermal steam is evaporated from the cooling towers with 25 percent injected as recharge into the reservoir. In recent years, large amounts of reclaimed waste water have been injected into the reservoir, and three older, less efficient plants have been decommissioned. These remedial actions resulted in stabilization of the overall system pressure. To date, the facilities at The Geysers have produced for 45 years, ${ }^{26}$ and geothermal facilities at The Geysers are expected to be economically profitable for several decades more. ${ }^{27}$. Improvements in technology and additional injection could increase the projected economically profitable lifespan even further. Unlike most other geothermal systems, no water flows naturally into The Geysers geothermal system. The Geysers is a rare "dry steam field," while most other geothermal reservoirs are liquiddominated and recharge naturally.

\section{Geothermal Potential}

With today's technology, it is assumed that geothermal power plants can economically generate electricity when resources rise above approximately $212^{\circ} \mathrm{F}\left(100^{\circ} \mathrm{C}\right)$ or are at depths of roughly 4 kilometers or less. ${ }^{28}$ In order for a resource to be economically developed at the minimum temperature, the resource must be relatively shallow. Likewise, in order for a resource to be developed at depths approaching 4 kilometers, the temperature must be relatively hot; thus these two parameters are somewhat offsetting. In addition, the size of the resource, productivity of wells, and other factors can influence economic viability. GEA plans to undertake an assessment of these different factors in the near future.

The last nationwide geothermal resource assessment (USGS Circular 790) was published in 1978, and a comparison of its findings with the current state of knowledge and development highlights some important points. ${ }^{29}$

- Circular 790 identified nine western states (Alaska, Arizona, California, Hawaii, Idaho, Nevada, New Mexico, Oregon and Utah) with the potential for at least 100 MW of electrical power generation per state from identified geothermal systems.

\footnotetext{
${ }^{26}$ Dr. Keshav Goyal, Senior Reservoir Engineer at The Geysers (2004). Statement of Evidence.

${ }^{27}$ While a number of plants at The Geysers have been decommissioned over the years, only one of these was closed due predominantly to steam declines. The other facilities were closed due to age, contractual, legal, or other problems, according to Calpine Corporation.

${ }^{28}$ Duffield, Wendell A and John H. Sass (2003). Geothermal Energy-Clean Power from the Earth 's Heat. USGSX, Circular 1249.

${ }^{29}$ Statement of Dr. Colin F. Williams, Supervisory Geophysicist (May 3, 2001). U.S. Geological Survey. Before The Subcommittee On Energy And Mineral Resources, Committee On Resources, U.S. House Of Representatives.
} 
- The total identified high temperature geothermal resource in these nine states was estimated at approximately $22,000 \mathrm{MW}$. Today, only California has realized a significant fraction (22\%) of this potential $(2,600$ out of $12,000 \mathrm{MW})$. If the entire estimated resource for these nine states could be exploited as electrical power, it would equal $21.5 \%$ of the electrical power generated from all other sources.

- USGS estimated that additional undiscovered resources ranged from 72,000 to $127,000 \mathrm{MW}$.

Technological developments during the last decade have increased the depth at which projects can be viably developed. Some new projects under consideration in the U.S. today involve resources near or below the previously assumed 4 kilometer limit. U.S. resource estimates do not effectively consider the potential for energy production from resources below these depths. A new U.S. Geological Survey (USGS) Assessment is being initiated and should provide important new information when completed. Small scale, "direct use" systems, which use the heat directly from the geothermal water rather than converting it to electricity, can be used effectively so long as waters are as low as $80^{\circ} \mathrm{F}\left(27^{\circ} \mathrm{C}\right)$. Figure 9 shows normal subterranean temperatures at 3 kilometers depth, ${ }^{30}$ while Figure 10 shows subterranean temperatures at 6 kilometers depth. ${ }^{31}$ Note the drastic expansion in potentially useful geothermal energy across the country as depth increases.

\footnotetext{
${ }^{30}$ Source: University of Utah Research Institute (UURI)

${ }^{31}$ Source: David Blackwell, Southern Methodist University (SMU) Geothermal Lab
} 
Figure 9: Estimated Subterranean Temperatures at 3 Kilometers Depth

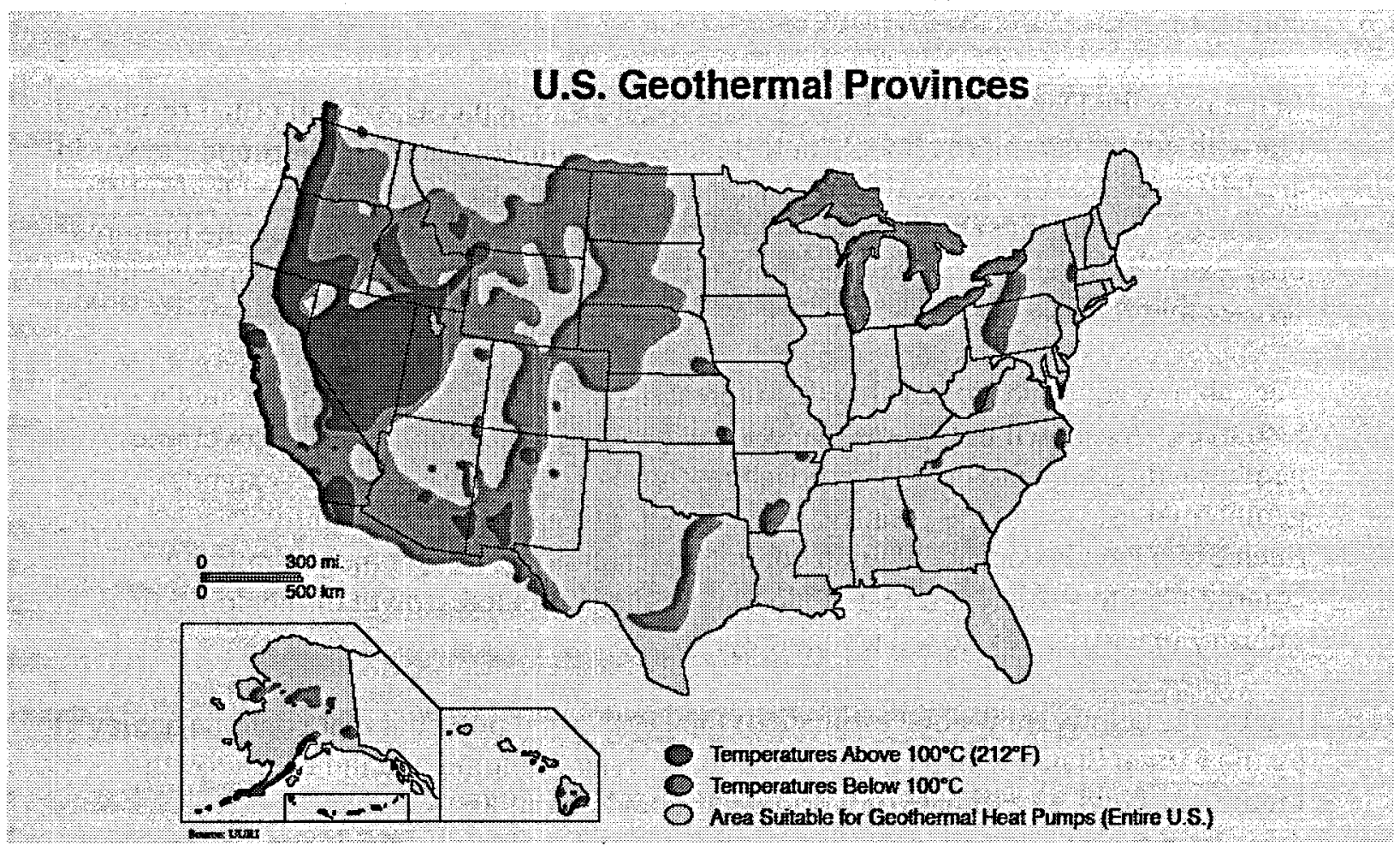

Figure 10: Estimated Subterranean Temperatures at 6 Kilometers Depth

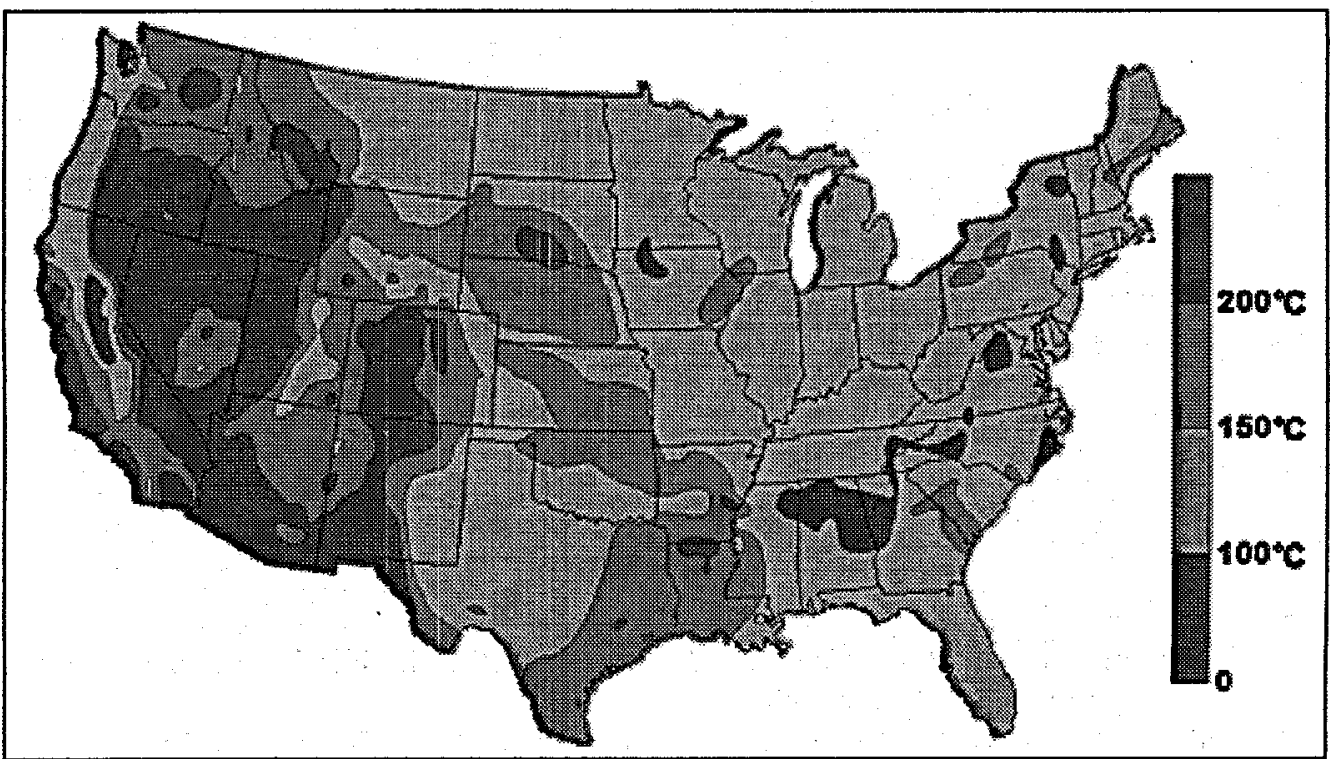


While Figure 10 shows subterranean temperatures at $6 \mathrm{~km}$, or 19,685 feet, the drilling depth record for the Gulf of Mexico was 33,200 feet on January 2004 (Shell Oil.). ${ }^{32}$ Oil and gas drilling technology has routinely allowed successful drilling to depths of $6 \mathrm{~km}$ and more.

In the past, the Department of Energy used Figure 9 to depict U.S. geothermal resources, but with continued improvements in technology, geothermal resources around the world are being accessed from depths greater than 10,000 feet using conventional hydrothermal resources. Today, the Department of Energy views Figure 10 as depicting the resource base that will be accessible with continued advances in research and development in the foreseeable future.

Technology continues to develop that increases our potential for extracting geothermal resources. As shown in Figures 9 and 10, expanding the economically recoverable geothermal resource to depths approaching those of oil and gas reserves extends geothermal use across the country, instead of limiting it to predominantly western areas. Such expansion is dependent upon continued technology development, implying a commitment to sufficient research along with the continued growth of the domestic industry to use the developed technology.

Figure 11, below, shows one estimate of the geothermal potential that could be achieved by the United States with a commitment to sufficient funding and industry growth.

Figure 12 shows an estimate of world geothermal potential. ${ }^{33}$

As shown, 1999 utilization of today's geothermal technology could produce many times more megawatts of geothermal energy than is currently being used. Federal, state, and independent research on enhanced technology is working to reduce cost and develop new technology to find, characterize, and engineer geothermal systems. The success of these efforts will allow commercial production from an increasingly large resource base.

\footnotetext{
${ }^{32}$ Geothermal Energy Association (2004). Geothermal Energy Potential. Retrieved November 10, 2004, from http://www.geo-energy.org/USGeoProv.pdf.

${ }^{33}$ Sources: Gawell, et al (1999). Geothermal Energy: the Potential for Clean Power from the Earth. Geothermal Energy Association, Washington, DC.
} 
Figure 11: U.S. Geothermal Potential

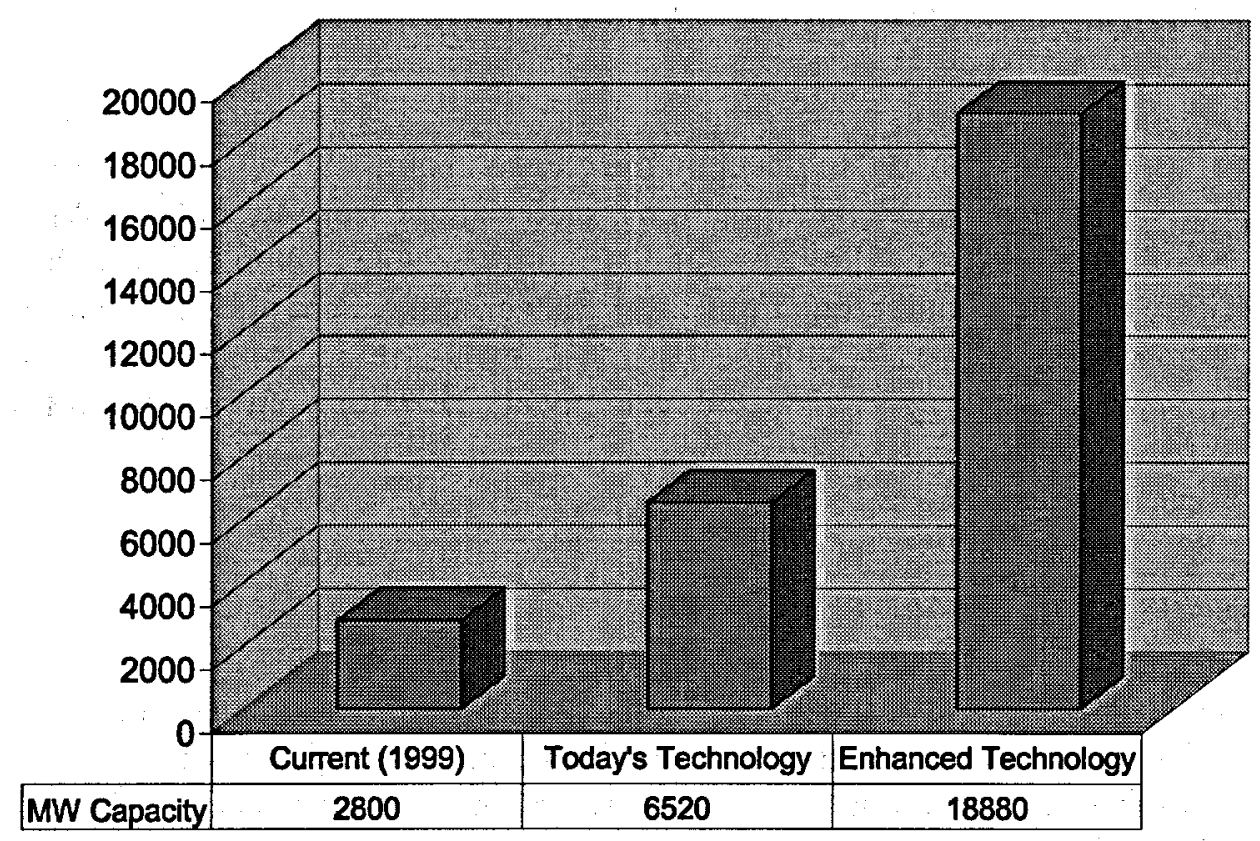

Figure 12: World Geothermal Potential

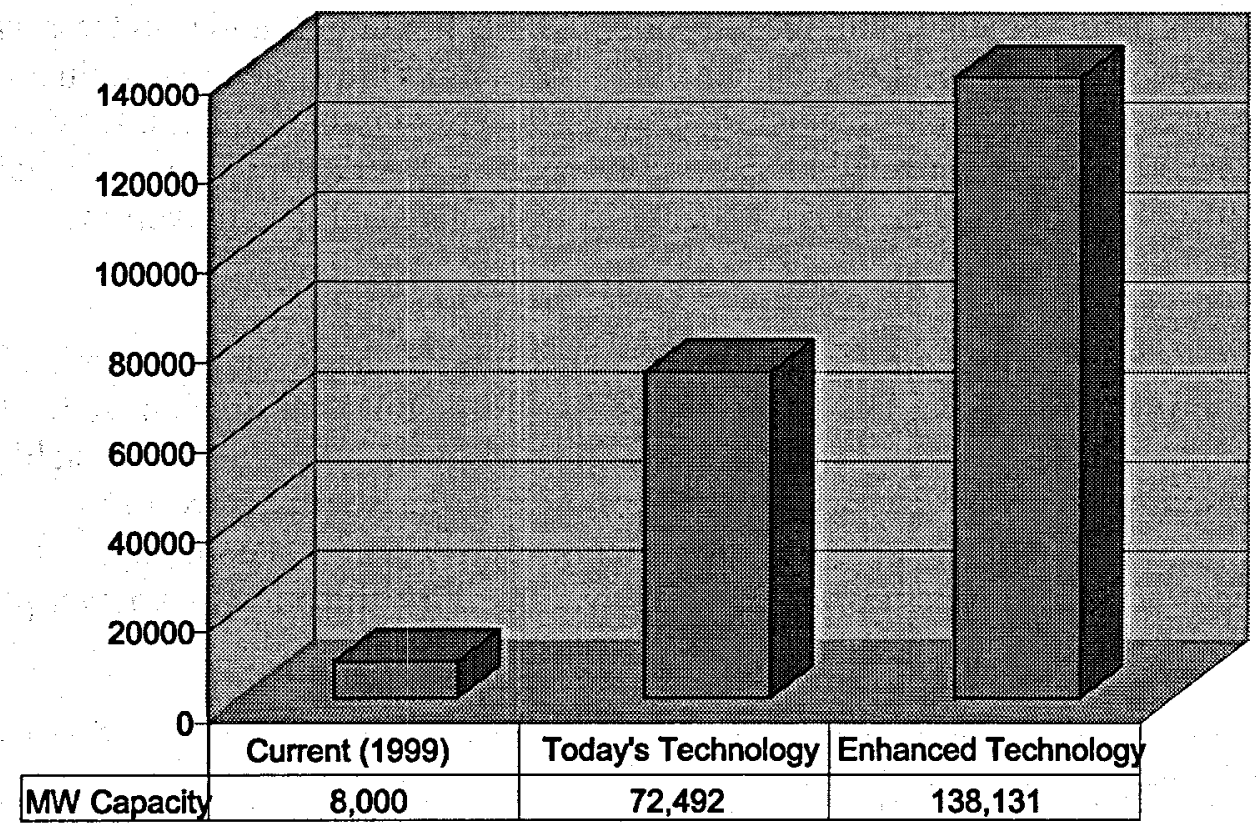




\section{Geothermal Energy and the Environment}

\section{Applicable Environmental Regulations - An Overview}

To understand geothermal energy and its impact on the environment, a brief overview of applicable regulations is necessary. Many regulations, such as the Clean Air Act (CAA), apply to all sources of emissions, including emissions from renewable technologies such as geothermal. These environmental regulations dictate specific levels of allowable air emissions, how permits can be issued, what sorts of environmental reviews must take place, and what land types may be approved for development. Development of any kind will impact the environment, and thus must follow specific regulations.

\section{Clean Air Act Regulations}

Several pollutants discussed in the subsequent section of this paper are regulated under the Clean Air Act (CAA) as criteria pollutants. A criteria pollutant is a principal pollutant identified as most harmful to people and the environment. The Clean Air Act sets National Ambient Air Quality Standards (NAAQS) to regulate emissions of criteria pollutants on a federal level. The six criteria pollutants regulated by NAAQS are carbon monoxide, lead, nitrogen dioxide, particulate matter, ozone, and sulfur dioxides. ${ }^{34}$ States containing nonattainment areas-geographic areas that do not meet NAAQS standardsare required to develop a State Implementation Plan (SIP), a strategy to meet NAAQ standards at the local and state level. States and tribes are responsible for meeting NAAQS standards under U.S. Environmental Protection Agency (EPA) oversight. State and local governments issue most of the air permits required by Title $V$ of the Clean Air Act. These air permits include enforceable air emissions limitations and standards as established by the state or local government. Title $V$ permits are issued to certain air pollution sources after they have begun to operate. In certain circumstances, for example on tribal lands, EPA may issue Title V permits as needed. EPA permits do not supersede state permits but rather serve areas not under traditional state and local government jurisdictions.

All emitting facilities must comply with federal emission standards under sections 111 and 112 of the Clean Air Act. Under section 111, sources built after September 18, 1978 are subject to particulate matter, sulfur dioxide, and nitrogen oxides standards established by the new source performance standards (NSPS), while those built before 1978 are not subject to federal regulation unless significant renovations occur at the facility. ${ }^{35}$ The uncertainty of what constitutes a significant renovation or modification to a power plant

\footnotetext{
${ }^{34}$ U.S. EPA (2004), National Ambient Air Quality Standards (NAAQS) Guidelines. Retrieved September 23, 2004, from http://www.epa.gov/air/criteria.html

${ }^{35}$ U.S. EPA. Air and Radiation (2004). Clean Air Act as Amended 1990. Retrieved September 20, 2004, from http://www.epa.gov/oar/caa/contents.html.
} 
has been the subject of recent controversy. Under section 112, "major" industrial facilities that emit one or more of 188 listed hazardous air pollutants, or air toxics, must be EPA regulated. EPA defines "air toxics" as those pollutants that are known or suspected of causing cancer or other serious health effects, such as developmental effects or birth defects. ${ }^{36}$

Because geothermal power plants emit pollutants at lower levels than those regulated by the Clean Air Act, they do not face the same constraints as new fossil fuel facilities seeking air and operating permits from state governments.

In California, the state with more geothermal electricity generation than any other area of the world, ambient air quality standards are stricter than national standards. Air districts in California with geothermal electricity production are required to comply with those strict air quality standards. Details about California air regulations are provided by the California Air Resources Board (CARB) and are web-accessible. ${ }^{37}$.

\section{Additional Regulations}

Under the National Environmental Policy Act (NEPA), any geothermal project selling power to a federal entity, moving power over a federal transmission line, or using federal funding or federal land must undergo an environmental analysis in order to determine potential environment impact. Power plants constructed on private or state lands are usually subject to similar state requirements. Depending upon the conclusions reached by the environmental review, additional studies, public hearings and documentation may be required before construction can begin. Any significant environmental impacts identified in an Environmental Assessment (EA) or Environmental Impact Statement (EIS) must be accompanied by a plan for monitored mitigation measures.

Other environmental regulations that address geothermal development include the Clean Water Act, the National Pollutant Discharge Elimination System Permitting Program (NPDES), the Safe Drinking Water Act (Underground Injection Control Regulations), the Resource Conservation and Recovery Act (RCRA), the Toxic Substance Control Act, the Noise Control Act, the Endangered Species Act, the Archaeological Resources Protection Act, Hazardous Waste and Materials Regulations, the Occupational Health and Safety Act, and the Indian Religious Freedom Act. ${ }^{38}$ The federal regulatory agencies involved in the geothermal development process include the Bureau of Land Management (BLM), the Forest Service, the Federal Energy Regulatory Commission (FERC), and the Fish and

\footnotetext{
${ }^{36}$ U.S. EPA (Jan 2004). Section 112 of the Clean Air Act. Retrieved April 21, 2005, from $\mathrm{http} / / / \mathrm{www}$. epa.gov/ttn/atw/112g/112gpg.html.

${ }^{37}$ For details about California's strict air emissions regulations, for which geothermal plants are regularly in compliance, please visit http://www.arb.ca.gov/htm1/lawsregs.htm.

${ }^{38}$ Brown, Kevin L. (1995). Environmental Aspects of Geothermal Development. International Geothermal Association Pre-Congress Course. CNR. Pisa, Italy.
} 
Wildlife Service. ${ }^{39}$ State and local regulations and agencies are also involved in the geothermal development process.

\section{Air Emissions}

Geothermal power plants release very few air emissions because they do not burn fuel like fossil fuel plants. Most fossil fuel power plant emissions are either a product of fuel combustion or a waste-product from that process. Geothermal plants avoid both environmental impacts associated with burning fuels as well as those associated with transporting and processing fuel sources. Geothermal plants emit only trace amounts of nitrogen oxides, almost no sulfur dioxide or particulate matter, and small amounts of carbon dioxide. The primary pollutant some geothermal plants must sometimes abate is hydrogen sulfide, which is naturally present in many subsurface geothermal reservoirs. With the use of advanced abatement equipment, however, emissions of hydrogen sulfide are regularly maintained below even California state standards.

It is important to note that air emissions from all power plants-including but not limited to geothermal - come from a variety of sources. For example, additional fossil fuel emissions, which come from the transportation of fuel to the power plant, are often omitted from emissions data. Unfortunately, air emissions comparisons are sometimes misleading, because the emissions data from a geothermal plant typically includes all emission sources from the well field through the power plant. A better comparison would include the complete range of emissions from fossil fuel plants. The lack of such data means that the comparisons that follow generally overstate the comparative emissions from geothermal power, and while this analytical problem cannot be resolved within the confines of this paper, it should be noted by the reader.

Average life cycle emissions at coal facilities are substantially higher than their average operational emissions, as show in Figure $13 .{ }^{40}$ Operational emissions do not consider the effects of coal mining, transport, construction, and decommissioning. Life cycle emissions from geothermal facilities, in contrast, generally remain in the same range as operational emissions.

\footnotetext{
${ }^{39}$ Fourmile Hill Geothermal Project Final EIS, vol 1.

${ }^{40}$ Source: Margaret Mann and Pamela Spath (1999). Life Cycle Assessment of Coal-Fired Power Generating System. (NREL/TP-570-25119). Retrieved March 3, 2005, from http://www.nrel.gov/docs/fy 99 osti/25119.pdf.

For operational source information, please see Figures 21, 24, and 26.
} 
Figure 13: Life Cycle versus Operational Emissions, Coal Power Plants

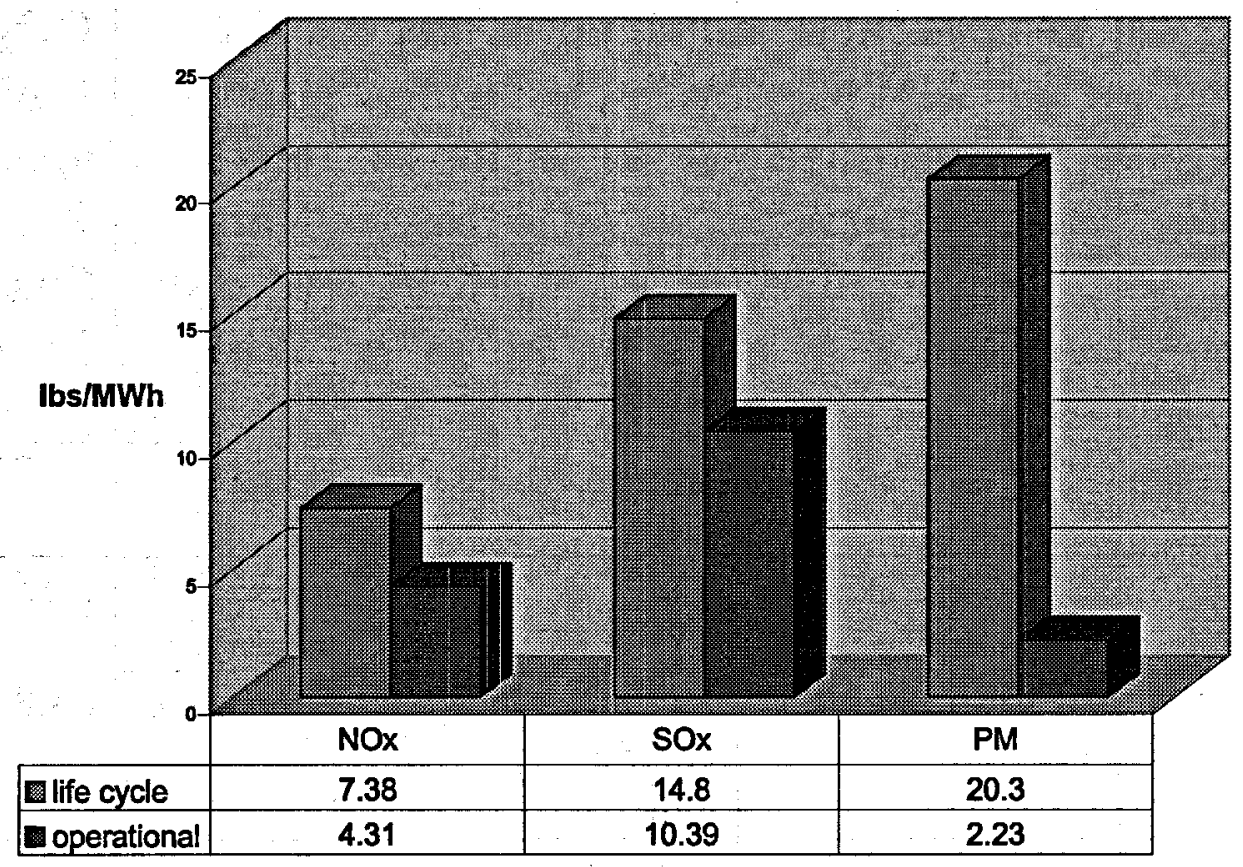

Even when comparing operational emissions alone, the current average geothermal generation of 15 billion kilowatt hours offsets harmful pollutants and greenhouse gases that would otherwise be generated by coal facilities each year, including 16 million tons of carbon dioxide, 78 thousand tons of sulfur oxides, 32 thousand tons of nitrogen oxides and 17 thousand tons of particulate matter. ${ }^{41}$

Table 2 below expresses in more precise, current terms the benefits of geothermal power production over coal power production. The data refers to specific working power plants. Note that even the more efficient coal plant, the Cherokee plant of 2003, where emissions controls have been installed as a result of the Denver Metro Emission Reduction Plan (MERP), ${ }^{42}$ emits 24 times more carbon dioxide, about 11,000 times more sulfur dioxide, and 4,000 times more nitrous oxides per megawatt hour than a geothermal steam plant. While a megawatt (MW) measures power capacity, a megawatt hour measures actual energy production. The measurement of megawatt hour (MWh) will be used to discuss comparable emissions from different types of power plants throughout this document.

\footnotetext{
${ }^{41}$ Based on average EIA estimate of yearly geothermal generation, 1990-2004, available at $\mathrm{http}: / / \mathrm{www}$.eia.doe.gov/emeu/aer/txt/ptb0802c.html, and using percentages of each type of generation based on gross capacity listed at GEA website, available at http:/www.geo-energy.org/Existing.htm. ${ }^{42}$ Xcel Energy (2004). Denver Metro Emissions Reduction Project [MERP]. Retrieved November 2004, from http://www.xcelenergy.com/XILWEB/CDA/0,3080,1-1-1_11824_11839 3731-1993-5 406 651$\underline{0,00 . \mathrm{html}}$.
} 


\begin{tabular}{|c|c|c|c|c|c|c|}
\hline Plant Name & $\begin{array}{l}\text { Yea } \\
\mathbf{r}\end{array}$ & $\begin{array}{l}\text { Total } \\
\text { MWh } \\
\text { produce } \\
\text { d during } \\
\text { specified } \\
\text { year }\end{array}$ & $\begin{array}{l}\text { Primar } \\
\text { y Fuel }\end{array}$ & $\begin{array}{l}\text { NOx } \\
\text { Emiss } \\
\text { ions } \\
\text { Rate } \\
\text { (lbs/ } \\
\text { MWh } \\
\text { ) }\end{array}$ & $\begin{array}{l}\mathrm{SO}_{2} \\
\text { Emissi } \\
\text { ons } \\
\text { Rate } \\
\text { (lbs/M } \\
\text { Wh) }\end{array}$ & $\begin{array}{l}\mathrm{CO}_{2} \\
\text { Emiss } \\
\text { ions } \\
\text { Rate } \\
\text { (lbs/ } \\
\text { MWh } \\
\text { ) }\end{array}$ \\
\hline $\begin{array}{l}\text { Cherokee } \\
\text { Station* }\end{array}$ & $\begin{array}{l}199 \\
7 \\
\end{array}$ & $4,362,809$ & Coal & 6.64 & 7.23 & 2,077 \\
\hline Cherokee Station & $\begin{array}{l}200 \\
3\end{array}$ & $5,041,966$ & Coal & 4.02 & 2.33 & 2,154 \\
\hline $\begin{array}{l}\text { Sonoma County } \\
\text { power plant at } \\
\text { The Geysers** }\end{array}$ & $\begin{array}{l}200 \\
3\end{array}$ & $5,076,925$ & $\begin{array}{l}\text { Steam } \\
\text { Geother } \\
\text { mal }\end{array}$ & .00104 & .000215 & 88.8 \\
\hline $\begin{array}{l}\text { Mammoth } \\
\text { Pacific*** }\end{array}$ & $\begin{array}{l}200 \\
4\end{array}$ & $210,000^{+}$ & $\begin{array}{l}\text { Binary } \\
\text { Geother } \\
\text { mal }\end{array}$ & 0 & 0 & 0 \\
\hline
\end{tabular}

*Cherokee is a coal-fired, steam-electric generating station; data on Cherokee plant (Colorado) provided by Xcel Energy.

**Values represent averages for 11 Sonoma County power plants at The Geysers. Data provided by Calpine Corporation as submitted to the Northern Sonoma County Air Pollution Control District for 2003 emissions inventory.

***Data provided by Bob Sullivan, plant manager at Mammoth Pacific, LP

+ Represents average yearly output rather than specific output for 2004 .

As shown, one of the most significant environmental benefits of geothermal energy is clean air, which translates into fewer respiratory health problems for the U.S. population. The American Lung Association estimates that power plant emissions, primarily from coal plants, result in over 30,000 yearly deaths. ${ }^{43}$ Greater use of geothermal power production can lower this number by decreasing air emissions. For example, Lake County, downwind of the world's largest geothermal field known as "The Geysers," is the only air district in California that has been in compliance with all state and federal air quality standards for 17 years.

${ }^{43}$ Garcia, Staci (Aug 2001). Air Pollution Impacts and Reduction Strategies Retrieved September 24, 2004, from http://www.nrel.gov/docs/gen/fy01/NN0060.pdf. 


\section{Myth 3: Geothermal Power Plants Emit Smoke}

Truth: the visible plumes seen rising from water cooled geothermal power plants are actually water vapor emissions (steam), not smoke, and are caused by the evaporative cooling system. No combustion of fuels occurs to produce electricity at a geothermal facility. Air cooled systems emit no water vapor, and thus blend easily into the environment. In a water cooling process, fifty percent or more of the geothermal fluid that enters the cooling tower is emitted to the atmosphere as water vapor, while the remainder recycles back into the reservoir. Geothermal water vapor emissions contain only trace amounts of the pollutants typically found in much greater quantities in coal and gas power plant emissions.

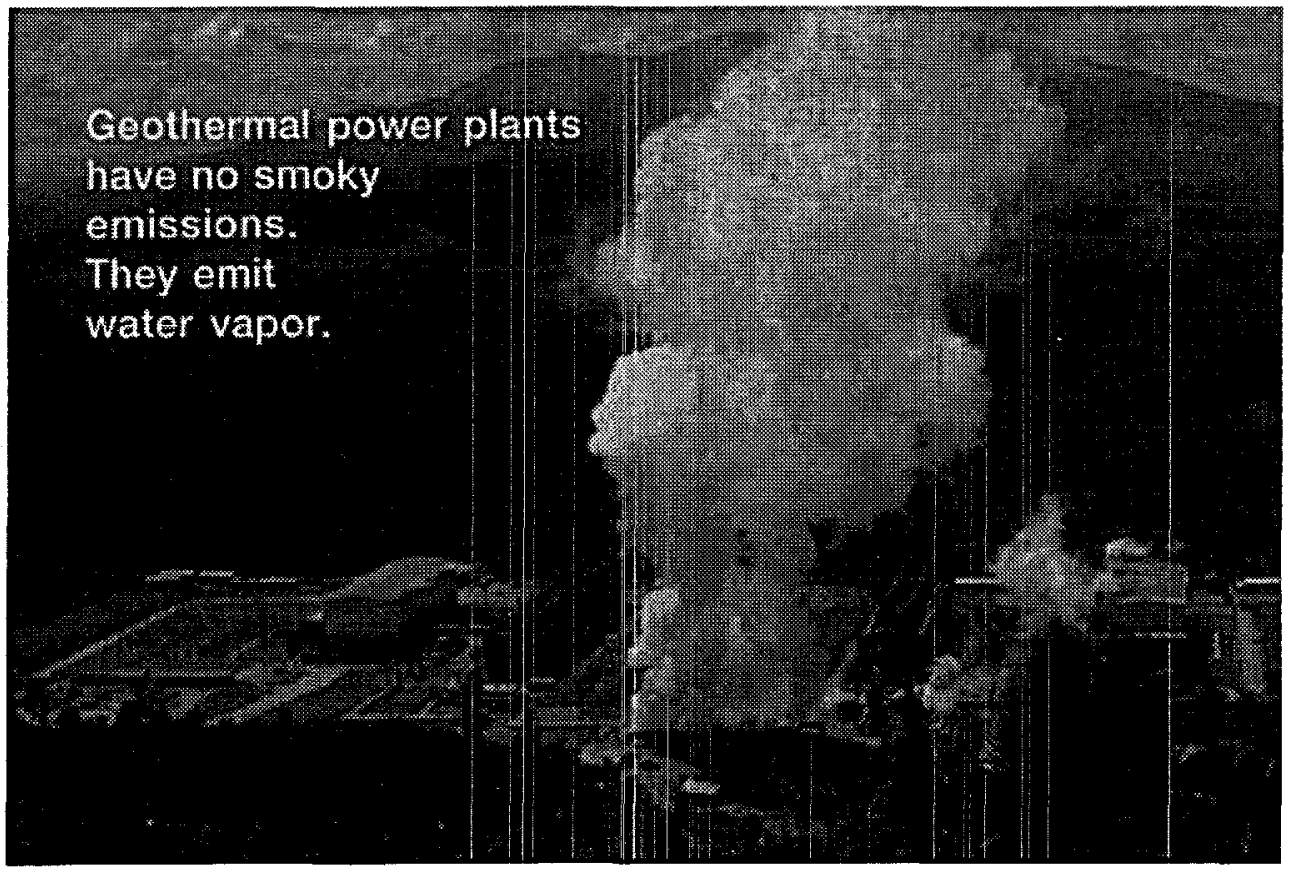

Source: Geothermal Education Office

\section{Nitrogen Oxides}

Nitrogen oxides (NOx) are often colorless and odorless, or reddish brown as nitrogen dioxide. Nitrogen oxides form during high temperature combustion processes from the oxidation of nitrogen in the air. Motor vehicles are the major source of these pollutants, followed by industrial fuel-burning sources such as fossil fuel-fired power plants. Fossil fuel-fired power plants are responsible for 23 percent of nitrogen oxide emissions. ${ }^{44}$

\footnotetext{
${ }^{44}$ U.S. EPA (2004). How Does Energy Use Affect the Environment? Retrieved September 29, 2004, from http://www.epa.gov/cleanenergy/impacts.htm
} 
Nitrogen oxides contribute to smog formation, acid rain, water quality deterioration, global warming, and visibility impairment. Health effects include lung irritation and respiratory ailments such as infections, coughing, chest pain, and breathing difficulty. ${ }^{45}$ Geothermal energy produced in the United States, when compared to coal, offsets approximately 32 thousand tons of nitrogen oxide emissions each year. ${ }^{46}$ This is substantial considering that even brief exposure to high levels of nitrogen oxides may cause human respiratory problems, and airborne levels of nitrogen oxides above the EPA established average allowable concentration of 0.053 parts per million ${ }^{47}$ can cause ecosystem damage. Nitrogen dioxide is a federally regulated criteria pollutant. Power plants built after September 17, 1978 must comply with federal nitrogen oxide standards; those built before may be subject to state or local standards.

Because geothermal power plants do not burn fuel, they emit very low levels of nitrogen oxides. In most cases, geothermal facilities emit no nitrogen oxides at all. The small amounts of nitrogen oxides released by some geothermal facilities result from the combustion of hydrogen sulfide. Geothermal plants are generally required by law (with some variation from state to state) to maintain hydrogen sulfide abatement systems that capture hydrogen sulfide emissions and either burn the gas or convert it to elemental sulfur. During combustion, small amounts of nitrogen oxides are sometimes formed, but these amounts are miniscule. Average nitrogen oxide emissions are zero, as shown in Figure 14. ${ }^{48}$

${ }^{45}$ U.S. EPA. Air Pollution (2004). Criteria Pollutants Description. Retrieved September 11, 2004, from http://www.epa.gov/air/oagps/eog/course422/ap5.html.

${ }^{46}$ Based on average EIA estimate of yearly geothermal generation, $1990-2004$, available at http://www.eia.doe.gov/emeu/aer/txt/ptb0802c.html, and using percentages of each type of generation based on gross capacity listed at GEA website, available at http://www.geo-energy.org/Existing.htm.

${ }^{47}$ U.S. Department of Health and Human Services. Agency for Toxic Substances and Disease Registry (ATSDR) (June 199). ToxFAQs ${ }^{\mathrm{TM}}$ for Nitrogen Dioxide. Retrieved February 2, 2005, from http://www.atsdr.cdc.gov/tfacts175.html.

${ }^{48}$ Sources: Coal and natural gas from Platts Researching and Consulting, based on data from the EPA's Continuous Emissions Monitoring Program, 20003. Oil from U.S. EPA (2005). Clean Energy Impacts. Retrieved January 10, 2005, from http://www.epa.gov/cleanenergy/oil.htm; Geothermal information from U.S. DOE, 2000. 


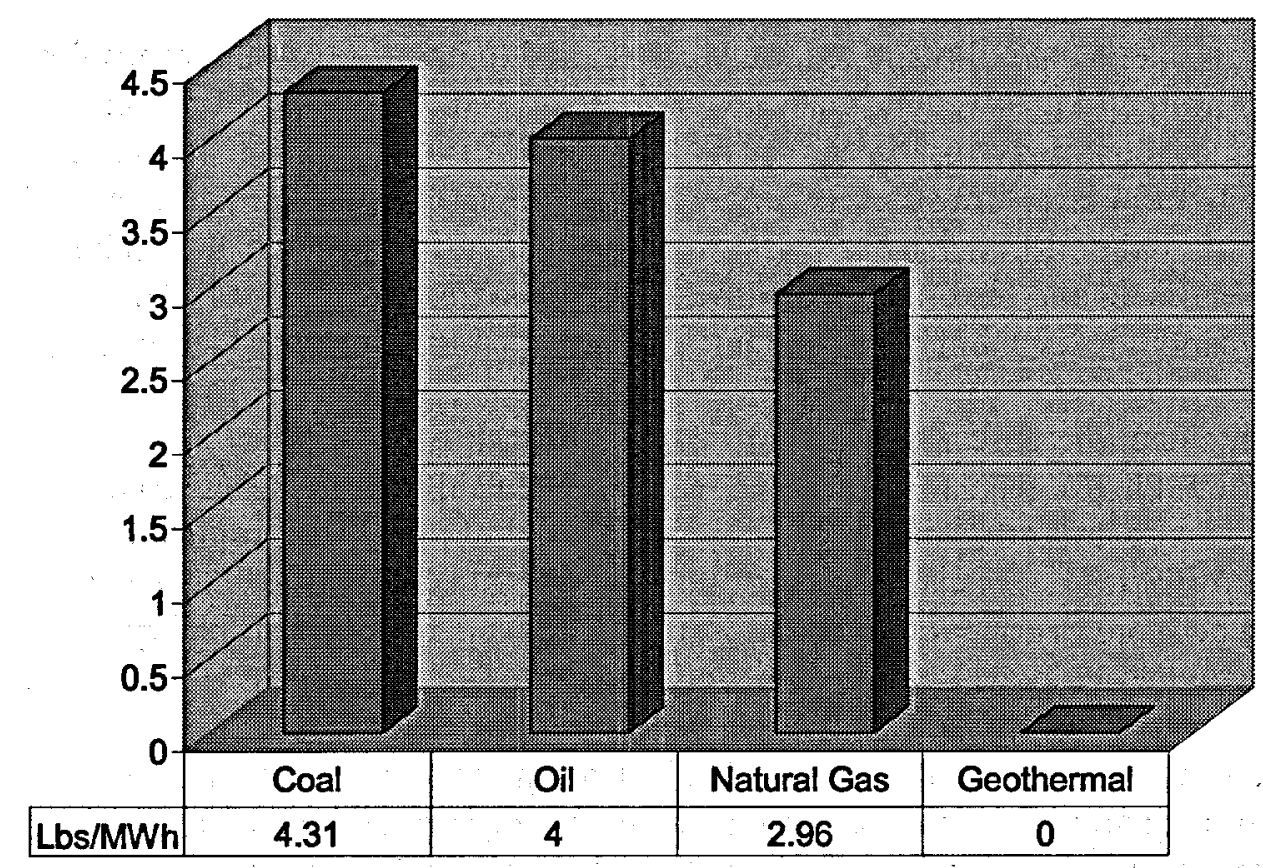

Coal, oil, and geothermal reported as average existing power plant emissions; natural gas reported as average existing steam cycle, simple gas turbine, and combined cycle power plant emissions.

\section{Hydrogen Sulfide}

Hydrogen sulfide $\left(\mathrm{H}_{2} \mathrm{~S}\right)$ is a colorless gas that is harmless in small quantities, but is often regarded as an "annoyance" due to its distinctive "rotten-egg" smell. Hydrogen sulfide can be lethal in high doses. Natural sources of hydrogen sulfide include volcanic gases, petroleum deposits, natural gas, geothermal fluids, hot springs, and fumaroles. Hydrogen sulfide may also form from the decomposition of sewage and animal manure, and can be emitted from sewage treatment facilities, aquaculture facilities, pulp and paper mills, petroleum refineries, composting facilities, dairies, and animal feedlot operations. ${ }^{49}$ Individuals living near a gas and oil drilling operation may be exposed to higher levels of hydrogen sulfide.

Anthropogenic (manmade) sources of hydrogen sulfide account for approximately 5 percent of total hydrogen sulfide emissions. ${ }^{50}$ Health impacts from high concentrations include nausea, headache, and eye irritation; extremely high levels can result in death.

\footnotetext{
${ }^{49}$ Idaho DOE Quality Document (2003). Health and Air Pollution: Hydrogen Sulfide. Retrieved September 22, 2004, from http://www.deq.state.id.us/air/hydrogen sulfide/FactSheet HS.pdf

${ }^{50}$ Tatum, Vickie L. (Oct. 1996) Health Effects of Hydrogen Sulfide. GRC Transactions, Vol. 20, pp. 37 39.
} 
Hydrogen sulfide remains in the atmosphere for about 18 hours. Though hydrogen sulfide is not a criteria pollutant, it is listed as a "regulated air pollutant."

Hydrogen sulfide remains the pollutant generally considered to be of greatest concern for the geothermal community. However, it is now routinely abated at geothermal power plants. The two most commonly used vent gas hydrogen sulfide abatement systems are the Stretford and LO-CAT. ${ }^{51}$ Both systems convert over 99.9 percent of the hydrogen sulfide from geothermal noncondensable gases ${ }^{52}$ to elemental sulfur, which can then be used as a soil amendment and fertilizer feedstock. The cost to transport and sell the sulfur as a soil amendment is about equal to the revenue gained from the transaction.

As a result of abatement measures, geothermal steam- and flash-type power plants produce only minimal hydrogen sulfide emissions. Hydrogen sulfide emissions from California geothermal plants are reported as below the limits set by all California air pollution control districts. ${ }^{53}$ This is significant, considering that California's clean air standards tend to be more restrictive than federal standards. Binary and flash/binary combined cycle geothermal power plants do not emit any hydrogen sulfide at all.

In terms of dry gas by volume, a California study cites, as an example, that hydrogen sulfide could comprise around 1 percent of noncondensable dry gas emitted by a given geothermal power plant. ${ }^{54}$ Considering all types of geothermal plants, that translates into an overall average of about $0.187 \mathrm{lbs}$ per megawatt hour. ${ }^{55}$ Since 1976 , hydrogen sulfide emissions from geothermal sources have declined from $1,900 \mathrm{lbs} / \mathrm{hr}$ to $200 \mathrm{lbs} / \mathrm{hr}$ or less, although geothermal power production has increased from 500 megawatts (MW) to over $2,000 \mathrm{MW}^{56}$

\section{Sulfur Dioxide}

Sulfur dioxide belongs to the family of SOx gases that form when fuel containing sulfur (mainly coal and oil) is burned at power plants. Fossil fuel-fired power plants are responsible for 67 percent of the nation's sulfur dioxide emissions. ${ }^{57}$ High concentrations of sulfur dioxide can produce temporary breathing impairment for asthmatic children and adults who are active outdoors. Health impacts from short-term exposures include

\footnotetext{
${ }^{51}$ For detailed information about LO-CAT systems, please visit http://www.gtp-merichem.com/.

52 Reed, Marshall J. and Joel L. Renner. (1995). Environmental Compatibility of Geothermal Energy. Alternative Fuels and the Environment, ed. F. S. Sterret Boca Raton: CRC Press, 1995.

${ }^{53}$ Tiangco, Valentino, et al. (1995). Emission Factors of Geothermal Power Plants in California. GRC Transactions, Vol. 19, pp 147-15.

${ }^{54}$ Bloomfield, K.K. and Joseph N. Moore (1999). Production of Greenhouse Gases from Geothermal Power Plants. GRC Transactions, Vol 23, pp 221 - 223.

${ }_{55}$ Bloomfield, Moore, and Neilson (March/April 2003). Geothermal Energy Reduces Greenhouse Gas Emissions. GRC Transactions. Vol 32:2.

${ }^{56}$ Altshuler, S.L. \& Arcado, T.D. (1991). Ambient Air hydrogen sulfide Monitoring at The Geysers: From Nonattainment to Attainment. GRC Special Report No. 17, 297-301.

${ }^{57}$ U.S EPA (2004). How Does Energy Use Affect the Environment? Retrieved September 29, 2004, from http://www.epa.gov/cleanenergy/impacts.htm
} 


\section{ख)}

wheezing, chest tightness, shortness of breath, aggravation of existing cardiovascular disease, and respiratory illness. Sulfur oxide emissions injure vegetation, damage freshwater lake and stream ecosystems, decrease species variety and abundance, and create hazy conditions. $^{58}$

There are both short- and long-term primary NAAQS for sulfur dioxide. The short term (24-hour) and secondary (3-hour) standards are not to be exceeded more than once per year. The current regulations were finalized in $1972 .^{59}$

While geothermal plants do not emit sulfur dioxide directly, once hydrogen sulfide is released as a gas into the atmosphere, it spreads into the air and eventually changes into sulfur dioxide and sulfuric acid. ${ }^{60}$ Therefore, any sulfur dioxide emissions associated with geothermal energy derive from hydrogen sulfide emissions.

When comparing geothermal energy to coal, the average geothermal generation of 15 billion kilowatt hours avoids the potential release of 78 thousand tons of sulfur oxides per year. For geothermal plants, Figure 15 below shows hydrogen sulfide emissions that have been converted, for comparison purposes, to sulfur dioxide. ${ }^{61}$

\footnotetext{
${ }^{38}$ World Bank Group (1998). "Sulfur Oxides," from Pollution Prevention and Abatement Handbook. Retrieved April 6, 2005, from http://wbln0018.worldbank.org/essd/essd.nsf/GlobalView/PPAH/\$File/41 sulfu.pdf

${ }^{59}$ U.S. EPA (2004). Sulfur Dioxide. Retrieved December 21, 2004, from http://www.epa.gov/airtrends/sulfur.html ${ }^{60}$ U.S. Department of Health and Human Services. Agency for Toxic Substances and Disease Registry (ATSDR) (June 199). ToxFAQs TM for Sulfur Dioxide. Retrieved December 21; 2004, from http://www.atsdr.cdc.gov/tfacts1 16.html

${ }^{61}$ Sources: Natural gas, coal, and geothermal data from: Platts Researching and Consulting, based on data from the EPA's Continuous Emissions Monitoring Program, 2003. Oil-fired data from U.S. EPA (2005). Clean Energy Impacts. Retrieved January 10, 2005, from http://www.epa.gov/cleanenergy/oil.htm.
} 
Figure 15: Sulfur Dioxide Comparison

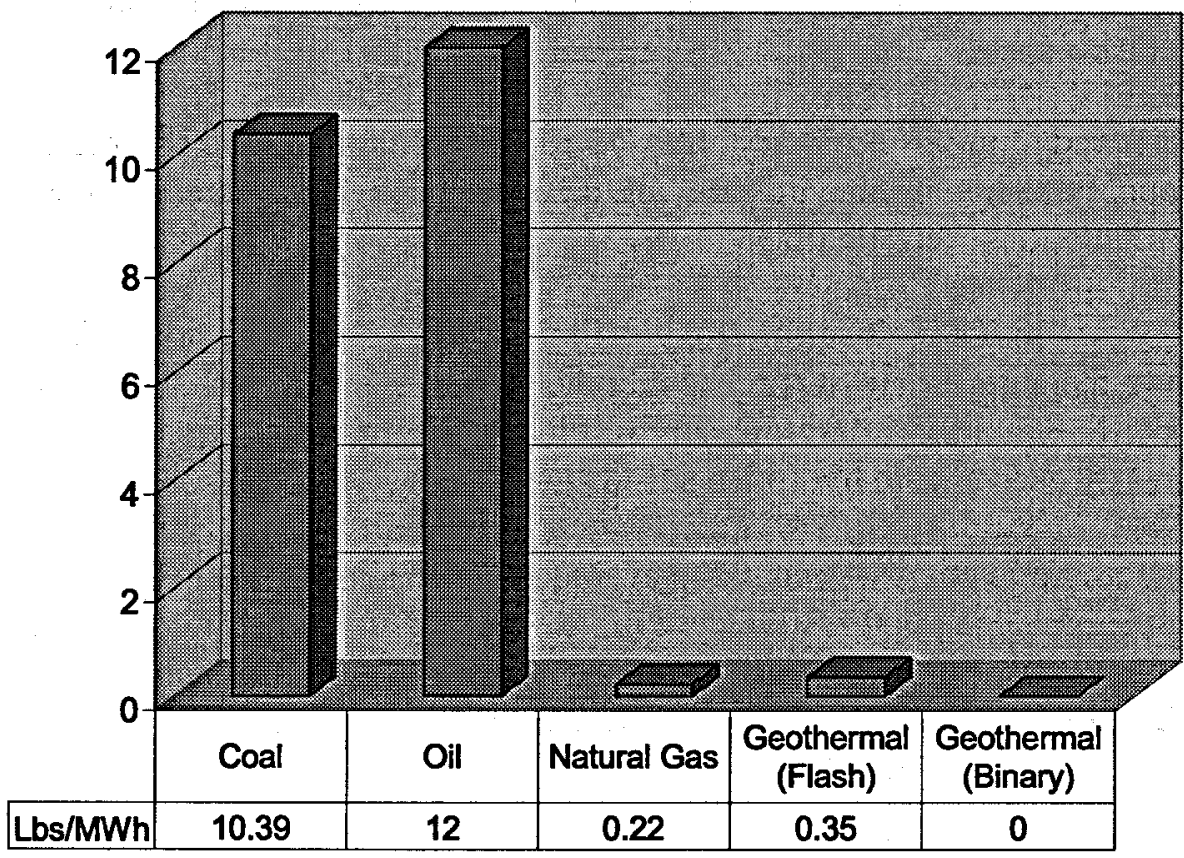

*Calculation converts hydrogen sulfide to sulfur dioxide for comparison only

Coal, oil, and geothermal reported as average existing power plant emissions; natural gas reported as average existing steam cycle, simple gas turbine, and combined cycle power plant emissions.

\section{Particulate Matter}

Particulate matter (PM) is a broad term for a range of substances that exist as discrete particles. Particulate matter includes liquid droplets or particles from smoke, dust, or fly ash. "Primary" particles such as soot or smoke come from a variety of sources where fuel is burned, including fossil fuel power plants and vehicles. "Secondary" particles form when gases of burned fuel react with water vapor and sunlight. Secondary particulate matter can be formed by NOx, SOx, and Volatile Organic Compounds (VOCs). Large particulates in the form of soot or smoke can be detected by the naked eye, while small particulates (PM2.5) require a microscope for viewing. PM10 refers to all particulates less than or equal to $\mathbf{1 0}$ microns in diameter of particulate mass per volume of air.

Particulate matter is emitted through the full process of fossil fuel electricity production, particularly coal mining. Health effects from particulate matter include eye irritation, asthma, bronchitis, lung damage, cancer, heavy metal poisoning, and cardiovascular 
complications. ${ }^{62}$ Particulate matter contributes to atmospheric deposition, visibility impairment, and aesthetic damage. Power plants built after September 17, 1978 must comply with federal PM10 standards; those built before that date may be subject to state or local standards.

Although coal and oil plants produce hundreds of short tons on an annual basis (where one short ton equals 2,000 pounds), as shown in Figure $16,{ }^{63}$ geothermal plants emit almost no particulate matter. Water-cooled geothermal plants do emit small amounts of particulate matter from the cooling tower when steam condensate is evaporated as part of the cooling cycle. However, the amount of particulate matter given off from the cooling tower is quite small when compared to coal or oil plants which have burning processes in combination with cooling towers. In a study of California geothermal plants, PM10 is reported as zero. ${ }^{64}$ It is estimated that geothermal energy produced in the United States offsets 17 thousand tons of particulate matter each year when compared to coal production.

Figure 16: Particulate Matter Comparison

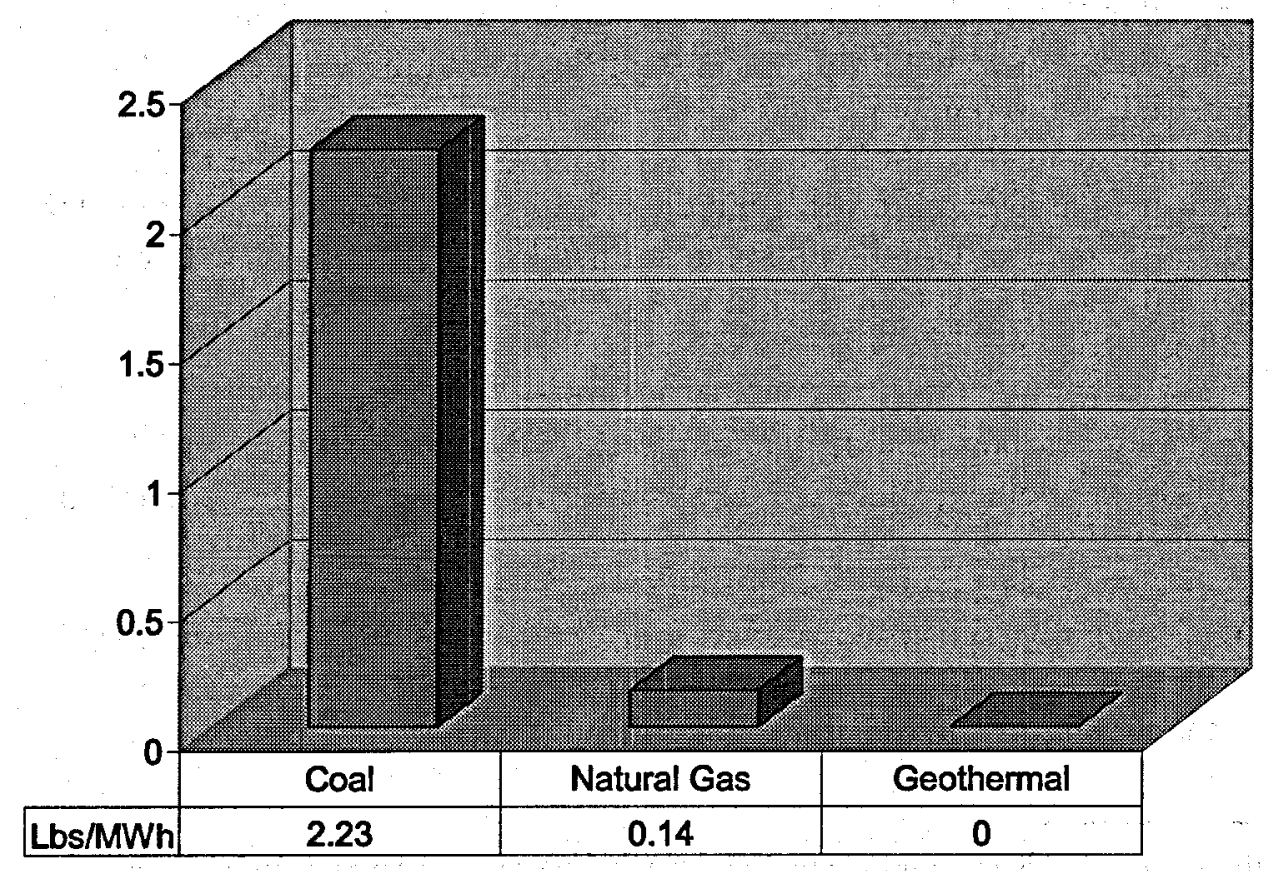

Comparing pulverized coal boiler, natural gas combined cycle, and average existing power plant, geothermal.

\footnotetext{
${ }^{62}$ U.S. EPA (2004), Effects of Air Pollution. Retrieved December 16, 2004, from http://www.epa.gov/air/oaqps/eog/course422/ap7a.html

${ }^{63}$ Source: Antares Group Inc., 4351 Garden City Drive, Suite 301, Landover, MD 20785.

${ }^{64}$ Tiangco, Valentino, et al. (1995): Emission Factors of Geothermal Power Plants in California. In GRC Transactions, 19, October. pp 147-151.
} 


\section{Carbon Dioxide}

Carbon dioxide, a colorless, odorless gas, is released into the atmosphere as a byproduct of burning fuel. While carbon dioxide emissions are also produced by natural sources, most experts agree that increased atmospheric carbon dioxide concentrations are caused by human fossil fuel burning. Concentrations in the atmosphere have increased by approximately 20 percent since $1960 .^{65}$ The increase in carbon dioxide is typically attributed to power plant (primarily coal) and vehicle emissions, and secondarily to deforestation and land-use change. About 37 percent of incremental carbon dioxide accumulation is caused by electric power generation, mainly from fossil fuels. ${ }^{66}$ According to the Energy Information Administration (EIA), carbon dioxide accounts for 83 percent of U.S. greenhouse gas emissions. ${ }^{67}$ While carbon dioxide does not pose any direct human health effects-humans exhale carbon dioxide with every breath - experts generally agree that global warming poses significant environmental and health impacts, including flood risks, glacial melting problems, forest fires, increases in sea level, and loss of biodiversity. ${ }^{68}$

The Kyoto Protocol, a document that addresses global warming through legally binding measures, was adopted in Kyoto, Japan, in 1997 by a number of developed and developing countries. ${ }^{69}$ However, not until the 2004 ratification of the Protocol by the Russian government did Kyoto regulations go into effect among the majority of the developed countries where legally binding measures are most prominent. The U.S., however, has not ratified the Kyoto Protocol, and thus U.S. power plants are not forced to comply with any international carbon dioxide regulations. U.S. power plants may be subject to state or local regulations, however, and those companies with business overseas may be affected.

Geothermal plants do emit carbon dioxide, but in quantities that are small compared to fossil fuel-fired emissions. Some geothermal reservoir fluids contain varying amounts of certain noncondensable gases, including carbon dioxide.

Geothermal steam is generally condensed after passing through the turbine. However, the carbon dioxide does not condense, and passes through the turbine to the exhaust system where it is then released into the atmosphere through the cooling towers. The

\footnotetext{
${ }^{65}$ Keeling, C.D. and T.P. Whorf (2004). Atmospheric $\mathrm{CO}_{2}$ records from sites in the SIO air sampling network. In Trends: A Compendium of Data on Global Change. Carbon Dioxide Information Analysis Center, Oak Ridge National Laboratory, U.S. Department of Energy, Oak Ridge, Tenn., U.S.A.

${ }^{66}$ Bloomfield, Moore, and Neilson (March/April 2003). Geothermal Energy Reduces Greenhouse Gas Emissions. GRC Transactions. Vol 32:2.

${ }^{67}$ EIA. U.S. DOE (2003). Emissions of Greenhouse Gases in the United States 2003. figure ES1. Retrieved March 15, 2005, from http://www.eia.doe.gov/oiaf/1605/ggrpt/executive summary.html.

${ }^{68}$ IPCC Third Assessment Report: Climate Change 2001. Stand-alone edition

Watson, R.T. and the Core Writing Team (Eds.) IPCC, Geneva, Switzerland. pp 184

http://www.ipcc.ch/pub/un/syreng/spm.pdf

${ }^{69}$ United Nations Framework Convention on Climate Change. Kyoto Protocol. Retrieved December 21, 2004, from http://unfccc.int/essential background/kyoto protocol/items/2830.php.
} 
amount of carbon dioxide found in geothermal fluid can vary depending on location, and the amount of carbon dioxide actually released into the atmosphere can vary depending on plant design. This makes it difficult to generalize about the amount of carbon dioxide emitted by an "average" geothermal power plant. For example, binary plants with air cooling are in a closed loop system and emit no carbon dioxide because in this system the geothermal fluids are never exposed to the atmosphere.

Despite these disparities, geothermal power plants will emit only a small fraction of the carbon dioxide emitted by traditional power plants on a per-megawatt hour basis. Figure 17 shows carbon dioxide emissions from the average geothermal plant compared with fossil fuel plants. ${ }^{70}$ Noncondensable gases such as carbon dioxide make up less than 5 percent by weight of the steam phase of most geothermal systems. ${ }^{71}$ Of that 5 percent, carbon dioxide typically accounts for 75 percent or more of noncondensable gas by volume. Because of the low level of carbon dioxide emissions, geothermal power production currently prevents the emission of 22 million tons of carbon dioxide annually when compared to coal production.

${ }^{70}$ Sources: Average emissions rates in the United States from oil-fired generation from U.S. EPA Clean Energy Impacts (2005). Retrieved January 10, 2005, from http://www.epa.gov/cleanenergy/oil.htm; coal and natural gas: Platt's Research and Consulting, based on data from EPA's Continuous Monitoring System (2003); geothermal: DOE data (2000).

${ }^{71}$ Reed, Marshall J. and Joel L. Renner. (1995). Environmental Compatibility of Geothermal Energy. In F. S. Sterret (Eds.), Alternative Fuels and the Environment. Boca Raton: CRC Press. 
Figure 17: Carbon Dioxide Comparison

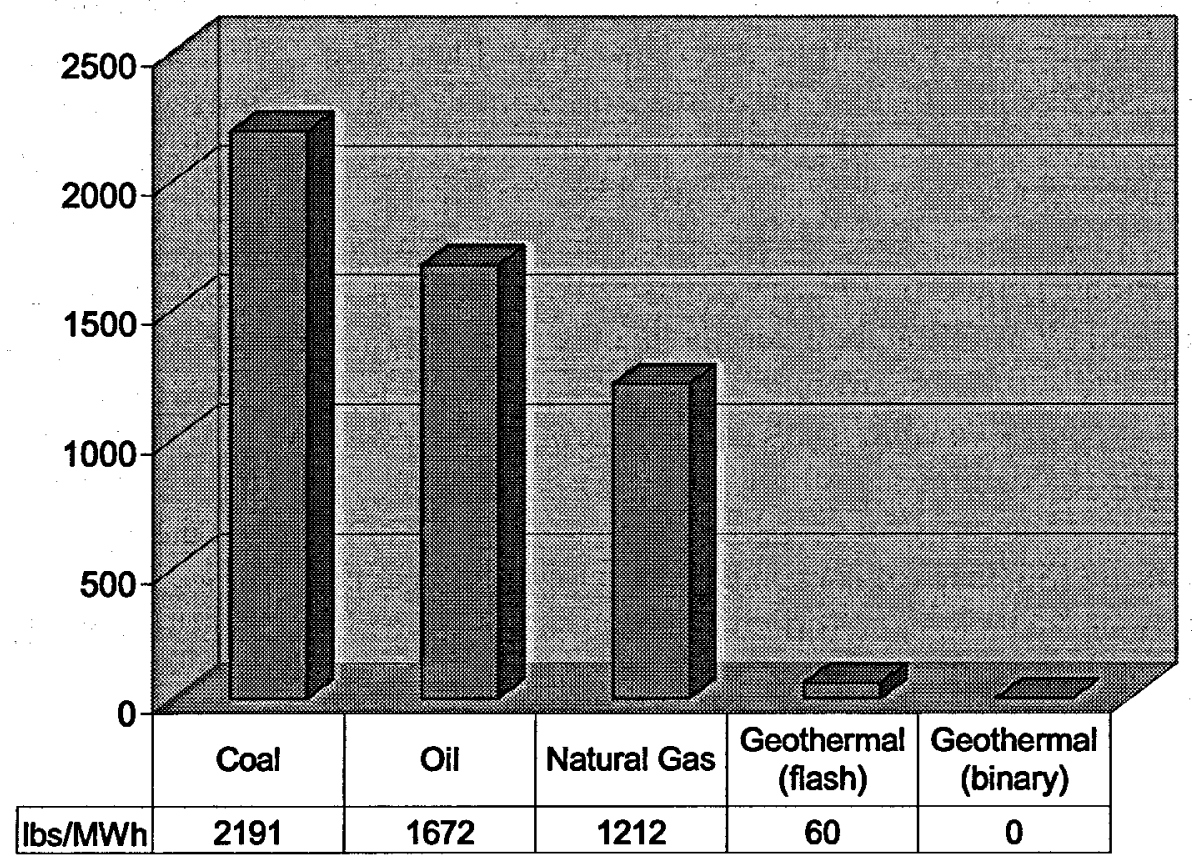

Coal, oil, and geothermal reported as average existing power plant emissions; natural gas reported as average existing steam cycle, simple gas turbine, and combined cycle power plant emissions.

\section{Mercury}

The majority of mercury emissions derive from natural sources. ${ }^{72}$ Mercury occurs naturally in soils, groundwater, and streams, but human activity can release additional mercury into the air, water, and soil. Coal-fired power plants are the largest source of additional mercury of any energy source, because the mercury naturally contained in coal is released during combustion. Currently, the coal industry contributes 32.7 percent of the nation's anthropogenic mercury emissions. ${ }^{73}$

Mercury emissions from coal vary both day to day and from plant to plant. According to a recent EPRI study, mercury emissions vary significantly over a one month period. Snapshot mercury emissions information, taken over a 1-2 hour period, does not always accurately reflect long term mercury emissions - hourly averages can vary by almost an order of magnitude. ${ }^{74}$ In addition, mercury emissions from certain types of coal plants,

\footnotetext{
${ }^{72}$ Feeley, Thomas J., et al. (April 2003). U.S.DOE/National Energy Technology Laboratory[NETL] Hg R\&D Program Review. A Review of DOE/NETL's Mercury Control Technology R\&D Program for CoalFired Power Plants. Retrieved November 3, 2004, from http://www.fossil.energy.gov/programs/powersystems/pollutioncontrols/mercurycontrols whitepaper.pdf ${ }^{73}$ U.S. EPA Mercury Study Report to Congress (Dec 1997). Retrieved September 30, 2004, from http://www.epa.gov/oar/mercury.html. ${ }^{74} \mathrm{Chu}$, Paul, et al. Longer-Term Mercury Emissions Variability. U.S. DOE. Retrieved November 8, 2004, from http://www.netl.doe.gov/coal/E\&WR/mercury/pubs/A3-3.pdf.
} 


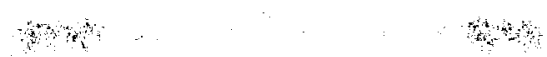

such as bituminous plants, tend to be greater than from other types of coal plants. It is estimated that bituminous plants emit 52 percent of coal mercury emissions, while lignite coal plants emit only 9 percent. $^{75}$. Those plants with emissions technologies in place, such as combined selective catalytic reduction (SCR) and wet flue gas desulphurization (FGD), tend to emit the lowest levels of mercury. This means that those plants built before 1978 that are not subject to Clean Air Act guidelines, and thus function without emissions control technologies, can emit ten times more mercury than newer, pollutioncontrolled coal plants. ${ }^{76}$

Mercury emissions from power plants pose a significant risk to human health. When mercury enters water, biological processes transform it to a highly toxic form, methyl mercury, which builds up in fish and animals that eat fish. People are exposed to mercury primarily by eating fish or by drinking contaminated water. ${ }^{77}$ Mercury is especially harmful to women: in February 2003, a draft report about mercury contamination noted that eight percent of women between the ages of 16 and 49 have mercury levels in the blood that could lead to reduced IQ and motor skills in their offspring. ${ }^{78}$ Mercury and mercury compounds are considered one of 188 Hazardous Air Pollutants (HAPs) and one of 33 urban HAPs under section 112 of the Clean Air Act. Urban HAPs are considered to present the greatest threat to public health in the largest number of urban areas. ${ }^{79}$ To date, EPA has established National Emission Standards for Hazardous Air Pollutants (NESHAPs) for mercury emissions, but these standards only apply to facilities such as mercury ore processing centers with high concentrations of mercury. Individual states can mandate specific regulations for individual facilities. ${ }^{80}$ In addition, the EPA issued draft regulations on March 15, 2005, under The Clean Air Mercury Rule, which limits federal mercury emissions through a market-based regulatory program. $^{81}$

Mercury is not present in every geothermal resource. However, if mercury is present in a geothermal resource, using that resource for power production could result in mercury emissions, depending upon the technology used. Because binary plants pass geothermal fluid through a heat exchanger and then return all of it to the reservoir, binary plants do not emit any mercury. In the United States, The Geysers is the main geothermal field known to emit small quantities of mercury in the atmosphere. The Geysers, however, was also mined for mercury from about $1850-1950$, so it is likely that some degree of

\footnotetext{
${ }^{75}$ Wayland, Robert J. (2001). Mercury and Utilities: Current Control Technologies. Northwest Mideast Institute/ECOS meeting, DC. Retrieved November 8, 2004, from http://www.nemw.org/Merc073101EPA.pdf.

${ }^{76}$ National Environmental Trust (2004), Power Plants and Your Health. Retrieved December 2, 2004, from http://environet.policy.net/cleanair/health/powerplantfactsheet.vtml.

${ }^{77}$ U.S. EPA (2004) Mercury Air Emissions. Retrieved June 18, 2004, from http://www.epa.gov/mercury/.

${ }^{78}$ Union of Concerned Scientists (2004). Scientific Integrity in Policy Making. Retrieved September 4, 2004, from http://www.ucsusa.org/global environment/rsi/page.cfm?pageID=1322.

${ }^{79}$ U.S. EPA Air Toxics Website (2004). List of 33 Urban Air Toxics. Retrieved September 23, 2004, from http://www.epa.gov/ttn/atw/urban/list33.html

${ }^{80}$ U.S. EPA Regulations (2004). Background Information on Mercury Sources and Regulations. Retrieved October 14, 2004, from http://www.epa.gov/grtlakes/bnsdocs/mercsrce/mercreg.html\#III.

${ }^{81}$ For text of regulations, please visit http://www.epa.gov/mercuryrule/. For information about market based regulatory programs, please visit http://www.epa.gov/airmarkets/.
} 
mercury emissions would exist independently of geothermal development. Within The Geysers, the presence of mercury in the steam varies dramatically, as around 80 percent of mercury emissions derive from only two facilities. These individual high mercury facilities are scheduled to install mercury abatement equipment in 2005 that will significantly reduce the overall geothermal mercury emissions. ${ }^{82}$. Furthermore, mercury emissions from The Geysers are below the amount required to trigger a health risk analysis under existing California regulations.

While federal proposals related to mercury risk have focused on coal, state and local governments have also introduced measures to reduce mercury emissions from other sources. As a result, mercury abatement measures are already in place at most geothermal facilities. The abatement measures that reduce mercury also reduce the emissions of sulfur generated as a byproduct of hydrogen sulfide abatement: after hydrogen sulfide is removed from geothermal steam, the gas is run through a mercury filter that absorbs mercury from the gas. In removing mercury, the sulfur that is created from the abatement process can then be used as an agricultural product. The rate of mercury abatement within a facility, which varies according to the efficiency of the activated carbon mercury absorber, is typically near 90 percent, and is always efficient enough to ensure that the sulfur byproduct is not hazardous. The activated carbon media is changed out periodically and is disposed of as a hazardous waste. The amount of hazardous waste reduction is thousands of tons/year.

\section{TOGs and ROGs}

Geothermal power plants may emit small amounts of naturally occurring hydrocarbons such as methane $\left(\mathrm{CH}_{4}\right)$. Methane is reported in Total Organic Gases (TOG). Ten percent of TOGs are assumed to be Reactive Organic Gas (ROG) emissions. TOGs consist of all compounds containing hydrogen and carbon, while ROGs consist of organics with low rates of reactivity. ${ }^{83}$ Methane is the primary TOG emitted by geothermal plants, followed by ethane and propane. ${ }^{84}$ The EPA's inventory of methane emission from electric plants does not list geothermal, confirming that methane emissions from geothermal are generally insignificant. ${ }^{85}$ In contrast, natural gas facilities emit 19 percent of domestic anthropogenic methane ${ }^{86}$ while coal mining and production accounts for around 20 percent. $^{87}$ Waste management accounts for the largest percentage of anthropogenic

\footnotetext{
${ }^{82}$ Benn, Brian J. (2004). Air Quality Specialist, Calpine Geysers Power Plant. Personal communication. ${ }^{83}$ CEC (2002). California Air Resources Board, Facility Search Engine. Retrieved November 4, 2004, from http://www.arb.ca.gov/app/emsinv/facinfo/facinfo.php.

${ }^{84}$ Benn, Brian J. (2004). Air Quality Specialist, Calpine Geysers Power Plant. Personal communication. ${ }^{85}$ U.S. EPA (2003). U.S. Emissions Inventory 2003, Electricity. Retrieved February 10, 2005, from http://yosemite.epa.gov/oar/globalwarming.nsf/content/ResourceCenterPublicationsGHGEmissionsUSEmis sionsInventory 2003.html.

${ }^{86}$ U.S. EPA, Global Warming (2004). Methane: Sources and Emissions. Retrieved October 5, 2004, from http://www.epa.gov/methane/sources.html

${ }^{87}$ Kirchgessner, David A. et al. (1995). An Improved Inventory of Methane Emissions from Coal Mining in the United States. U.S. EPA and Southern Institute. Retrieved November 4, 2004, from http://www.epa.gov/ttnchiel/ap42/ch14/related/mine.pdf.
} 
methane emissions, at over 26 percent. $^{88}$ Methane emission estimates are uncertain, however, because they are usually accidental or incidental to biological processes, and they are not always present in geothermal systems.

Other ROGs, such as benzene, a known carcinogen, are generally not of concern to the geothermal community, as they are injected back into the system. Benzene emissions released at most geothermal facilities, including the Salton Sea in southern California, have never been high enough to trigger a risk assessment under California EPA exposure level standards. Although the Heber geothermal facility in southern California was required to conduct quarterly benzene cooling tower analysis as a stipulation in their permit agreement, ${ }^{89}$ analyses indicated that benzene comprises less than 1 percent of cooling tower gases. ${ }^{90}$

\section{Ammonia}

Naturally occurring ammonia $\left(\mathrm{NH}_{3}\right)$ is emitted at low levels by geothermal facilities, with more concentrated amounts emitted by certain plants at The Geysers. While livestock is responsible for almost half of ammonia emissions, geothermal accounts for only a fraction of ammonia emissions, at substantially lower than one percent. Additional sources include fertilizers, crops, and biomass burning. ${ }^{91}$ Emitted ammonia can combine with water to form $\mathrm{NH}_{4} \mathrm{OH}$ (ammonium hydroxide). If it lasts long enough in the environment, ammonia may combine with nitrogen oxide to form particulate (ammonium nitrate) or if there are no acid gasses present in the atmosphere, it will be absorbed into the soil and taken up by green plants. ${ }^{92}$ Experts generally concur that ammonia is released as hydrated ammonia, and depending upon the environment, is absorbed in soil to become part of the nitrogen cycle.

\section{Boron $^{93}$}

Boron, an element found in volcanic spring waters, does not exist naturally in its elemental form, but is commonly found as a mineral salt, "borax", in dry lake evaporite

\footnotetext{
${ }^{88}$ Energy Information Administration (2003). Emissions of Greenhouse Gases in the United States. (DOE/EIA-0573(2003) 2003). Retrieved January 4, 2005, from ftp://ftp.eia.doe.gov/pub/oiaf/1605/cdrom/pdf/ggrpt/057303.pdf.

${ }^{89}$ U.S. EPA (October 1998). Region 9 Electronic Permit Submittal System. Retrieved April 14, 2005, from http://yosemite.epa.gov/R9/AIR/EPSS.NSF/0/0c56d26d860c3fcd8825669100777b2d?OpenDocument.

90 Cal ifornia Air Resources Board (CARB) (1998). Imperial County Air Pollution Control District. Major Facility Permit Review. Retrieved April 14, 2005, from http://www.arb.ca.gov/fcaa/tv/tvinfo/permits/imp/ogdenev.doc

${ }^{91}$ U.S. Department of Agriculture (USDA) (2000). Ammonia and Ammonium Emissions. Retrieved February 10, 2005, from http://www.ars.usda.gov/research/programs/programs.htm?np code=203\&docid=320.

${ }_{92}$ Benn, Brian (2004). Air Quality Specialist, Calpine Geysers Power Plant. Personal communication.

${ }^{93}$ Benn, Brian (April 2005). Air Quality Specialist, Calpine Geysers Power Plant. Personal communication.
} 
deposits. Boron is only toxic when high concentrations are ingested. When present in soil at low concentrations, boron is essential to the normal growth of plants. ${ }^{94}$

In geothermal steam systems, boron is present in the steam as highly soluble boric acid. When combined with ammonia, it often forms white crystalline salt deposits on equipment exposed to geothermal steam. Because of its high solubility, nearly all borate entering a geothermal plant will dissolve in the steam condensate, where it exits the plant through cooling tower blowdown and is injected back into the steam reservoir. New geothermal plants are now required to install high efficiency drift eliminators for particulate control regardless of boron content in the water, and these eliminators reduce boron emissions.

CalEnergy, the previous owner of the Coso geothermal facility, conducted a cooling drift monitoring study at their facility from 1987 until the early 1990's as part of compliance with a stipulation in the project development EIS. The purpose of this study was to examine the potential impacts of cooling tower boron on vegetation. After the examination showed no negative boron impacts at the Coso site, the CEC allowed the company to terminate regular monitoring procedures. Boron salt compounds may be emitted in cooling tower drift, but boron emissions are generally not regulated.

\section{Air Emissions: Concluding Overview}

Total noncondensable gas emissions from geothermal resources typically make up less than five percent of the total steam emitted, ${ }^{95}$ whereas air emissions from facilities such as coal contain much higher percentages of emissions.

Geothermal air emissions are significantly lower than those of an average U.S. power plant. For example, the geothermal sulfur dioxide equivalent, derived from hydrogen sulfide emissions, is one of the most significant pollutants emitted from geothermal power plants. Even so, sulfur dioxide emitted by geothermal facilities, at $0.35 \mathrm{lbs} / \mathrm{MWh}$, represents only a fraction of the $6.04 \mathrm{lbs} / \mathrm{MWh}$ of sulfur dioxide generated by the average U.S. power plant. Table 3 below summarizes the average air emissions information provided in charts throughout this document, along with the average U.S. power plant emissions. The data shows that geothermal facilities emit less air pollution than most other thermal energy sources.

\footnotetext{
${ }^{94}$ Brown, Kevin L. (1995). Environmental Aspects of Geothermal Development. International Geothermal Association Pre-Congress Course. CNR. Pisa, Italy.

${ }^{95}$ Reed, Marshall J. and Joel L. Renner. (1995). Environmental Compatibility of Geothermal Energy. In F. S. Sterret (Eds.), Alternative Fuels and the Environment. Boca Raton: CRC Press.
} 
Table 3: Air Emissions Summary

\begin{tabular}{|l|l|l|l|l|}
\hline lbs per megawatt hour: & $\begin{array}{l}\text { Nitrogen } \\
\text { Oxides }\end{array}$ & $\begin{array}{l}\text { Sulfur } \\
\text { Dioxide }\end{array}$ & $\begin{array}{l}\text { Carbon } \\
\text { Dioxide }\end{array}$ & $\begin{array}{l}\text { Particulate } \\
\text { Matter }\end{array}$ \\
\hline Coal .. & 4.31 & 10.39 & 2191 & 2.23 \\
\hline $\begin{array}{l}\text { Coal, life cycle } \\
\text { emissions }\end{array}$ & 7.38 & 14.8 & not available & 20.3 \\
\hline Oil & 4 & 12 & 1672 & not available \\
\hline Natural Gas & 2.96 & 0.22 & 1212 & 0.14 \\
\hline $\begin{array}{l}\text { EPA Listed Average } \\
\text { of all U.S. Power } \\
\text { Plants }\end{array}$ & 2.96 & 6.04 & 1392.5 & not available \\
\hline $\begin{array}{l}\text { Geothermal (flash) } \\
\vdots\end{array}$ & 0 & 0.35 & 60 & \\
\hline $\begin{array}{l}\text { Geothermal (binary } \\
\text { and flash/binary) }\end{array}$ & 0 & 0 & 0 & 0 \\
\hline $\begin{array}{l}\text { Geothermal (Geysers } \\
\text { steam) }\end{array}$ & .00104 & .000215 & 88.8 & negligible \\
\hline
\end{tabular}

\section{Solid and Liquid Waste}

In all U.S. geothermal facilities, air emissions are the most significant environmental issue of concern. Solid wastes discharged from geothermal power plants are nonhazardous under the federal Resource Conservation and Recovery Act (RCRA) and in low quantities. ${ }^{97}$ While solid wastes produced by geothermal facilities are sometimes regulated under California regulations, geothermal facilities are cited by the EPA as producing no substantial solid waste during generation. ${ }^{98}$ The substances listed in this section are typically either too low to cause any concern, or are recycled through the system and do not make contact with water, land, or air. Solid and liquid waste substances are included in this report to provide as comprehensive as possible a review of the environmental aspects of geothermal energy.

${ }^{96}$ U.S. EPA (2000). Average Power Plant emissions from EPA 2000 emissions data, http://www.epa.gov/cleanenergy/egrid/highlights, accessed 10/5/04.

${ }^{97}$ Were, Joshua O. (Oct 2003). An Overview of Waste Management Aspects of Geothermal Development. GRC Transactions. Vol 27:12-15, pp. 511-516.

${ }^{98}$ U.S. EPA (2004). Electricity from Non-Hydroelectric Renewable Energy Sources. Retrieved January 10, 2005, from http://www.epa.gov/cleanenergy/renew.htm\#geothermal. 
Arsenic, in its pure form, is a gray, crystalline solid, but can be found in various forms in the natural environment in combination with other elements. Arsenic is produced naturally in the Earth's crust and can be emitted during volcanic eruptions. It is also produced in fossil fuel processing and in the production of pesticides, wood preservatives, glass, and other materials. It is a known human carcinogen. Additional health effects include sore throat, irritated lungs, nausea, vomiting, decreased production of red and white blood cells, abnormal heart rhythm, damage to blood vessels, and skin pigmentation abnormalities. 99

Like all HAPs, monitoring of arsenic from its sources is not required under the Clean Air Act. However, the Safe Drinking Water Act currently mandates that arsenic not exceed $50 \mathrm{ppb}$ (parts per billion) in drinking water. Legislation is presently under review that would reduce the number to $10 \mathrm{ppb}$, as per the recommendations of a governmentsponsored study by the nonprofit organization, Academic Press. EPA limits exposure to arsenic in industrial facilities, but power plants remain unregulated. Individual states can have specific regulations for individual facilities, but no federal ambient air arsenic standards exist. ${ }^{100}$ Arsenic takes its final form in sediment, soil, water sources, shellfish, or fish, and is most harmful in the inorganic, as opposed to organic, form. ${ }^{101}$

Geothermal plants are not considered to be high arsenic emitters even though arsenic is common to volcanic systems. When arsenic is present in a geothermal system, it typically ends up in the solid form in the sludge and scales associated with production and hydrogen sulfate abatement. Arsenic emission levels have been well documented over the years through two emissions inventories in California: the Air Toxic "Hot Spots" Program and The Geysers Air Monitoring Programs (GAMP), both of which have shown limited arsenic emissions. Results of these programs have shown arsenic emissions levels from geothermal power plant to be very small, if they are even detectable. A study of The Geysers showed that arsenic emissions were not of significant concern: the average level at The Geysers, at around $1.6 \mathrm{ng} \mathrm{m}^{-3}$, was found to be very close to the statewide average of $1.5 \mathrm{ng} \mathrm{m}^{-3} .102$

\footnotetext{
${ }^{99}$ National Academic Press, for the Agency for Toxic Substances and Disease Registry [ATSDR] and the Dept of Health and Human Services (2000). Arsenic in Drinking Water: An Update. Retrieved November 20, 2004, from http://www.nap.edu/books/0309076293/html/.

${ }^{100}$ U.S. EPA Regulations (2004). Background Information on Mercury Sources and Regulations. Retrieved October 14, 2004, from http://www.epa.gov/grtlakes/bnsdocs/mercsrce/mercreg.html\#III.

${ }^{101}$ U.S. Dep of Health and Human Services, Public Health Service (2000) Agency for Toxic Substances and Disease Registry (ATSDR): Toxicological Profile for Arsenic. Retrieved October 15, 2004, from http://www.atsdr.cdc.gov/toxprofiles/tp2.html.

${ }^{102}$ Solomon, Paul. A (October 1991). Arsenic Speciation in Atmospheric Aerosols at The Geysers. GRC Transactions. Vol. 15.
} 


\section{Silica and Other Waste Products}

Silica, an abundant element that is the primary component of sand, is a byproduct of geothermal power production from certain brine reservoirs. Silica is typically dewatered, and the silica sludge is disposed of off site. ${ }^{103}$ Silica is only considered a potential hazard when found in high concentrations in the workplace, but it poses no environmental risk. Silica is found in the effluents, or treated wastewaters, that are the byproducts of drilling operations in some resources. ${ }^{104}$ Concentrations of silica are low enough in geothermal facilities that workers are not at risk. Silica is unregulated by the federal government. Other geothermal effluents are generally considered to be harmless, and even, at times, beneficial to the environment (see "Injection of Geothermal Fluids").

The primary "waste" in geothermal operations is drilling cuttings, comprised primarily of bentonite, a naturally occurring clay. Wastes from drilling activities, mud and cuttings, are stored in what are known as "sumps" for disposal according to state and federal regulations. Sumps provide secure storage for drilling mud and cuttings. They are typically lined with impervious materials to prevent leaching.

\section{$\underline{\text { XI. Noise Pollution }}^{105}$}

There are various federal and local noise pollution regulations for geothermal power plants with which geothermal developers must comply. On the federal level, regulations of the BLM, an agency under the Department of Interior (DOI), mandate that noise at $1 / 2$ mile, or at the lease boundary, if closer, from major geothermal operations shall not exceed 65 units of decibels A-weighted, or dBA. Sound is measured in units of decibels (dB), but for environmental purposes is usually measured in decibels A-weighted (dBA). A-weighting refers to an electronic technique which simulates the relative response of the human auditory system to the various frequencies comprising all sounds. Table 4 shows common sound levels along with geothermal sound levels. ${ }^{106}$.

\footnotetext{
${ }^{103}$ Brophy, Paul (1997). Environmental Advantages to the Utilization of Geothermal Energy. Renewable Energy. Vol. 10:2/3. pp. 367-377.

${ }^{104}$ Were, Joshua O. (2003). An Overview of Waste Management Aspects of Geothermal Development. GRC Transactions. Vol 27:12-15. pp. 511-516.

${ }^{105}$ Telephone Flat Environmental Impact Statement.

${ }^{106}$ Source: Telephone Flat Environmental Impact Statement, 3.7-4
} 
Table 4: Common Sound Levels

\begin{tabular}{|c|c|}
\hline Noise Source & Sound Level (dBA) \\
\hline Geothermal normal operation & $15-28$ \\
\hline Near leaves rustling from breeze & 25 \\
\hline Whisper at 6 feet & 35 \\
\hline Inside average suburban residence & 40 \\
\hline Near a refrigerator & 40 \\
\hline Geothermal construction & $51-54$ \\
\hline Geothermal well drilling & 54 \\
\hline Inside average office, without nearby & 55 \\
\hline telephone ringing & 60 \\
\hline Speech at 3 feet, normal voice level & 65 \\
\hline Auto (60 miles per hour) at 100 feet & 70 \\
\hline Vacuum cleaner at 10 feet & 80 \\
\hline Garbage disposal at 3 feet & 85 \\
\hline Electric lawn mower at 3 feet & 90 \\
\hline Food blender at 3 feet & 100 \\
\hline Auto horn at 10 feet & \\
\hline
\end{tabular}

In addition to BLM federal regulation, local city and county noise ordinances will vary from site to site. However, geothermal power plants can operate in compliance with the applicable regulations and are not considered a noise nuisance in surrounding residential communities. All power facilities must meet local noise ordinances according to the phase of construction and operation.

Noise pollution from geothermal plants is typically considered during three phases: the well-drilling and testing phase, the construction phase, and the plant operation phase. During the construction phase, noise may be generated from construction of the well pads, transmission towers, and power plant. During the operation phase, the majority of noise is generated from the cooling tower, the transformer, and the turbine-generator building.

Construction is one of the noisiest phases of geothermal development, but even construction noise generally remains below the $65 \mathrm{dBA}$ regulation established by the BLM. For example, according to the EIS completed for the proposed Telephone Flat geothermal development, construction noise was estimated to be $51 \mathrm{dBA}$ at a $1 / 2$ mile distance. The EIS further found that even if two well pads were constructed simultaneously, noise levels would not rise above $54 \mathrm{dBA}$, well below the $65 \mathrm{dBA}$ BLM regulations. Furthermore, noise pollution associated with the construction phase of geothermal development, as with most construction, is a temporary impact that ends when construction ends. Well pad construction can take anywhere from a few weeks or months to a few years, depending upon the depth of the well. In addition, construction 
noise pollution is generally only an issue during the daytime hours and is not a concern at night.

The well-drilling and testing phase of geothermal development generally does not exceed the federal BLM noise regulations. Much like the construction phase of development, well-drilling and testing are temporary, and the noise pollution they produce is not permanent. The Telephone Flat EIS for the proposed geothermal development estimated that well drilling operations would not exceed $54 \mathrm{dBA}$. However, unlike the construction phase of development, well-drilling operations typically take place 24 hours per day, seven days a week. This temporary noise pollution can last anywhere from 45 to 90 days perwell.

Noise from normal power plant operation generally comes from the three components of the power plant: the cooling tower, the transformer, and the turbine-generator building. According to the Telephone Flat EIS, noise from normal power plant operation at the cite boundary would occupy a range of 15 to $28 \mathrm{dBA}$ - below the level of a whisper (table 4).

Several noise muffling techniques and equipment are available for geothermal facilities. During drilling, temporary noise shields can be constructed around portions of drilling rigs. Noise controls can also be used on standard construction equipment, impact tools can be shielded, and exhaust muffling equipment can be installed where appropriate. Because turbine-generator buildings are usually designed to accommodate cold temperatures, they are typically well-insulated acoustically and thermally, and equipped with noise absorptive interior walls.

\section{Water Ouality and Use}

Geothermal water is a hot, often salty, mineral-rich liquid withdrawn from a deep underground reservoir. The steam that is "flashed" from the hot water is used to turn turbines and generate electricity. The remaining water, along with the condensed steam, is then injected back into the geothermal reservoir to be reheated. In water cooled systems, 50 percent or more of the liquid is lost to the atmosphere in the form of steam, and the remainder is injected back into the system. Because the geothermal water in a binary, air cooled plant is contained in a closed system, binary power plants do not consume any water. In a geothermal facility, geothermal water is isolated during production, injected back into the geothermal reservoir, and separated from groundwater by thickly encased pipes, making the facility virtually free of water pollutants.

Most geothermal reservoirs are found deep underground, well below groundwater reservoirs. As a result, these deep reservoirs pose almost no negative impact on water quality and use. While no record of water use problems exists in the U.S., potable groundwater and clean surface water are important resources that require continued attention as the use of domestic geothermal resources grows. 


\section{Injection of Geothermal Fluids}

Geothermal steam and hot water can reach the surface in two ways: through naturally occurring surface features such as geysers and fumaroles, or through man-made wells that are drilled down into the reservoir to capture the Earth's energy for electricity. In either case, these natural geothermal fluids contain varying concentrations of potentially toxic minerals and other elements and are extremely hot when they reach the surface of the Earth. For these reasons, geothermal waters can be dangerous to humans and surrounding ecosystems. This is just one of the reasons that geothermal fluids used for electricity are injected back into geothermal reservoirs and are not allowed to be released into surface waterways. Injection of spent geothermal fluids is regulated by the EPA to coincide with the Underground Injection Control Program requirements and the BLM and state well construction requirements to ensure that groundwater is protected. When geothermal fluids are injected back into a geothermal system, the fluids are isolated from shallow groundwater by thick well casing. Injection typically takes place in separate wells that are designed to properly handle the chemistry of the injection fluids. In addition, geothermal developers manage geothermal fluids in order to minimize potential impacts. Benefits of injection include enhanced recovery of geothermal fluids, reduced subsidence (see "Subsidence" section) and safe disposal of geothermal fluids. ${ }^{107}$

Occasionally, geothermal effluents, if stored rather than injected back into the system, deliver beneficial environmental effects. For example, injection was banned at the Amedee geothermal field in northeastern California because the effluent, stored in a holding tank, produced a diverse, thriving wetland. In another case, an evaporative pond at a Mexican geothermal facility was found to be occupied by 34 species of birds. ${ }^{108}$ Finally, few people realize that the Icelandic tourist attraction, the Blue Lagoon (a turquoise body of mineral rich water) was actually created by geothermal water discharged from a power plant. ${ }^{109}$ Not only is the Blue Lagoon safe for swimming, but the waters are also touted as "soothing," and as sources of "curative powers. ${ }^{110 \text { " }}$ Although the United States geothermal community agrees that injection is the most environmentally beneficial method of disposing of geothermal fluids, there are instances where other beneficial approaches have been taken.

\footnotetext{
${ }^{107}$ California Division of Oil, Gas, and Geothermal Resources (2004). Geothermal Injection Wells. Retrieved November 4, 2004, from http://www.consrv.ca.gov/DOG/geothermal/general info/injection wells.htm.

${ }^{108}$ Gomez, Maria C. et al. (1995). Evaporation Pond as a Refuge for Aquatic Birds in "Cerro Prieto" Geothermal Field, Baja California, Mexico. World Geothermal Conference [WGC]. Vol. 4. pp. 2803. ${ }^{109}$ Geotimes, Dec. 2003. http://www.geotimes.org/dec03/Travels1203.html. Retrieved November 9, 2004. 110 The Official North American website of the Icelandic Tourist Board (1997-98). The Blue Lagoon. InterKnowledge Corp. Retrieved January 3, 2005, from http://www.icelandtouristboard.com/.
} 
Figure 18: Blue Lagoon: Tourist Attraction and Geothermal "Wastewater"

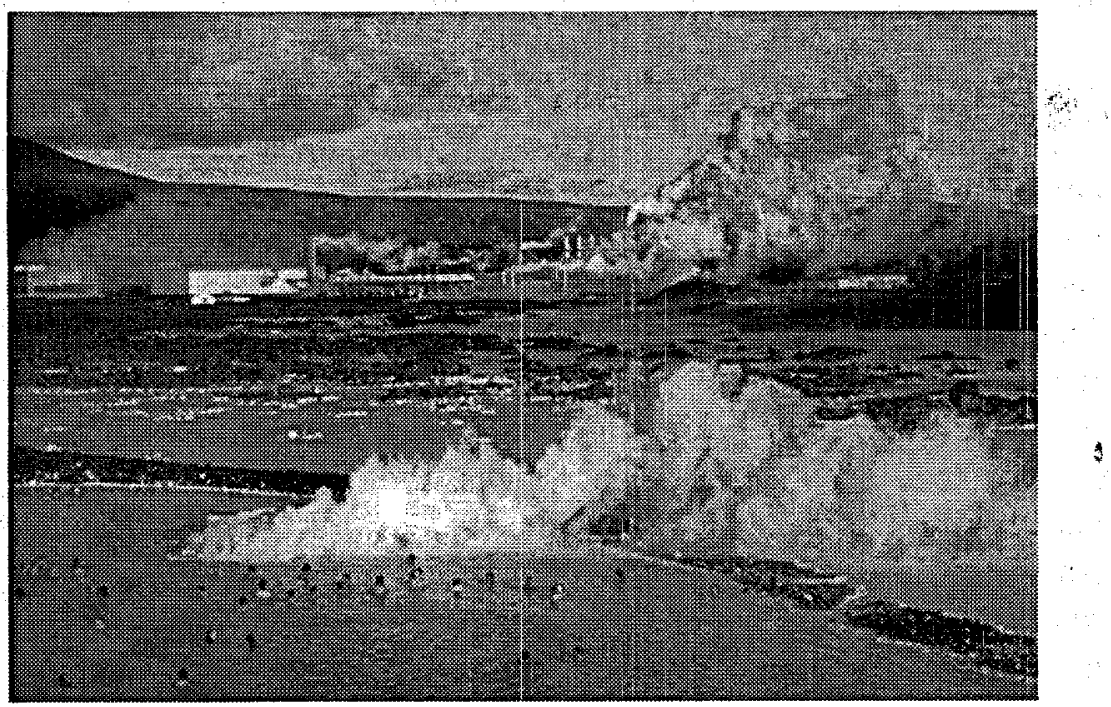

Source: Geo-Heat Center

Wastewater Injection: Success at The Geysers

Geothermal plants have the potential to improve local water quality. So-called "waste water injection" projects serve the dual purpose of eliminating wastewater, which would otherwise be dumped into local waterways, and rejuvenating geothermal reservoirs with new water sources. A wastewater injection project was initiated at The Geysers geothermal reservoir in December of 2003. Treated wastewater from the nearby community of Santa Rosa had been previously discharged directly into the Russian River, prompting state water quality regulators to take action against the community. Now, 11 million gallons of treated wastewater from Santa Rosa are being pumped daily to The Geysers for injection into the geothermal reservoir. Any residual biological contamination in the wastewater is instantly sterilized upon contact with the reservoir rock (usually above $400^{\circ} \mathrm{F}$ ). The project has also been of great help in maintaining the sustainability of the geothermal reservoir. The additional water being pumped into the geothermal reservoir has helped recharge the resource to make full use of the heat still trapped in the Earth's rock and has slowed the decline of the resource. The $\$ 250$ million project has so far proven to be a great success in reducing surface water pollution for the community of Santa Rosa, and has also helped to improve the sustainability of the geothermal reservoir. 
Myth 4: Extraction and Injection of Geothermal Brines Contaminates Drinking Water.

Truth: No contamination of groundwater has occurred as a result of geothermal activity. While groundwater contamination has been a problem in the past or in areas outside the U.S., today every effort is made by the geothermal industry to minimize the affects of geothermal development on local water regime and surface features. Geothermal brines are injected back into geothermal reservoirs using wells with thick casing to prevent cross-contamination of brines with groundwater systems. A well casing is composed of thick specialized pipe ${ }^{111}$ surrounded by cement in order to prevent any contamination as the geothermal fluids are put back into the reservoir. Once the brines are returned to the geothermal reservoir, they are re-heated by the Earth's hot rocks, and can be used over and over again to produce electricity. Besides voluntary mitigation efforts on the part of developers, certain geothermal activities, such as injection, are regulated by the EPA to coincide with the Underground Injection Control Program requirements and the BLM and state well construction requirements. These federal regulations were instituted with the specific intent of protecting groundwater resources. In the U.S., according to federal regulations, only the lower-temperature geothermal waters that are of drinking-water quality and that do not disrupt ecosystems might be allowed to flow into streams or lakes. Most geothermal applications, including all higher-temperature geothermal systems, require that the water be injected back into the reservoir.

Although geothermal development does not contaminate groundwater, like any form of development, it has some impact on local water use. For geothermal developers, most water impacts occur during construction and are only temporary. However, regardless of the nature or degree of water use impacts, geothermal developers should prioritize sound reservoir management practices that benefit geothermal operation and preventatively minimize potential impact.

Geothermal power plants do use surface or groundwater during the construction and operation of the power plant as well as during well drilling to sustain operations. These uses, while typically not a significant concern as they do not dramatically decrease the amount of ground and surface water available for potable uses, should be taken into account during the development of geothermal resources.

Fossil fuel plants, in contrast to geothermal facilities, must contend with water discharge and thermal pollution throughout the life of the plant, and waste heat from fossil fuel and nuclear facilities can devastate the animals and plants that inhabit local water bodies. ${ }^{112}$ In addition, both coal and nuclear plants use more water per megawatt hour than geothermal facilities in cooling their high-temperature fluids. Heated water is often

\footnotetext{
${ }^{111}$ Depending on the site and chemistry, the pipe could be made from titanium, stainless steal, or K55 carbon steel.

${ }^{112}$ Reed, Marshall J. and Joel L. Renner. (1995). Environmental Compatibility of Geothermal Energy. In F. S. Sterret (Eds.), Alternative Fuels and the Environment. Boca Raton: CRC Press.
} 
dumped into local bodies of water, creating environmental disruption from the intake and heating processes.

While geothermal production can typically be sustained through the use of a carrier medium (liquid or steam), a fossil fuel facility relies upon outside water sources. Figure 19 below shows freshwater use during normal operation at two proposed electricityproducing facilities, The Telephone Flat geothermal facility and the Sutter natural gas facility, both proposed projects of Calpine Corporation. ${ }^{113}$ The geothermal water use figure does not include geothermal fluid, as this liquid is injected back into the system and is not withdrawn from existing freshwater resources. At these facilities, according to the submitted Applications for Certification, the $500 \mathrm{MW}$ natural gas combined-cycle facility would use over 4 million gallons of water a day, while the $48 \mathrm{MW}$ flash evaporative cooling geothermal facility would use under 6 thousand gallons per day, even when the plants are adjusted for megawatt capacity.

${ }^{113}$ Source, geothermal: Telephone Flat Environmental Impact Statement 3.2-32, 3.2-34, 3.2-35; natural gas: Calpine Corporation Sutter Power Plant Project, Application for Certification (AFC) (Dec 1997). Table 2.2-1, Estimated Average Daily Water Requirements.

NOTE ON CALCULATIONS: Telephone Flat (geothermal)was proposed to produce $48 \mathrm{MW}$ and use an average of 6.5 acre feet/year, Sutter (natural gas) was proposed to produce $500 \mathrm{MW}$ and use an average $4,336,000$ gals/day. Numbers based on the assumptions that one acre-foot $=$ approximately 325,851 gallons, as reported by USGS (http://water.usgs.gov/pubs/circ/2004/circ1268/htdocs/text-conversion.html) and that the water usages are averaged over a 24 hour a day, 365 day a year time period. 


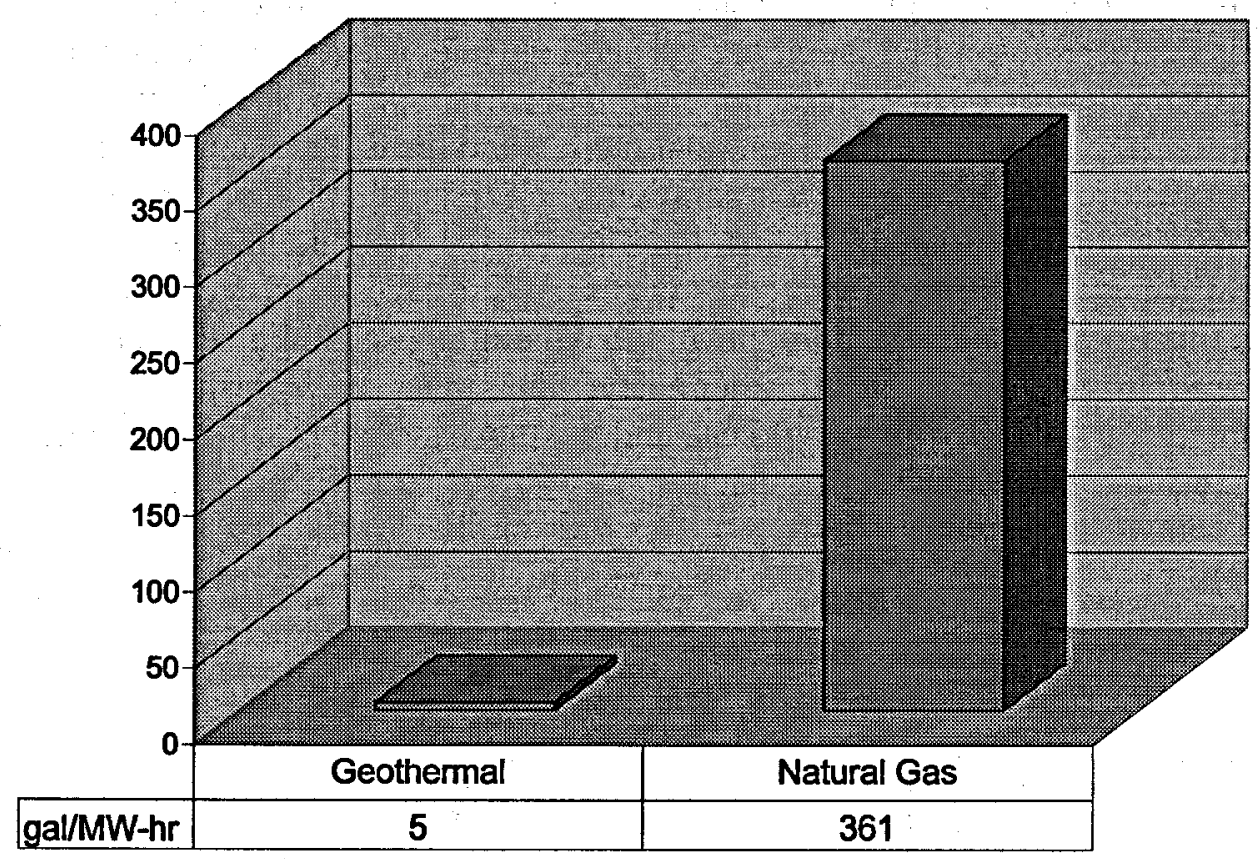

During normal operations, liquid wastes from drilling activities are stored in lined sumps before being properly disposed of in accordance with state regulations. ${ }^{114}$ Accidental spills of geothermal waters may occur due to well blowouts during drilling, leaking piping or wellheads, or overflow from well sumps. However, these incidents are rare, and are generally prevented through sound management practices by geothermal developers. BLM Geothermal Resources Operational Order No. 2 and state regulations set guidelines for maintaining wells to prevent blowouts and mandate proper well casing and drilling techniques. Overall, any negative effect of geothermal development on surface waterways would be accidental, and even then, by following federal and state laws, their impact would be kept minimal.

\section{Land Use}

Geothermal power plants can be designed to "blend-in" to their surrounding more so than many other types electricity-producing facilities. Binary and flash/binary power plants normally emit no visible steam or water vapor plumes, and flash and steam plants produce minimal visual impacts. The picture below shows the flash/binary Puna Geo Venture facility, located in Hawaii. This plant blends into its surroundings and produces no steam plumes, while still utilizing high temperature resources.

${ }^{114}$ Telephone Flat Environmental Impact Statement, 3.2-40. 
Figure 20: Puna Flash/Binary Geothermal Plant

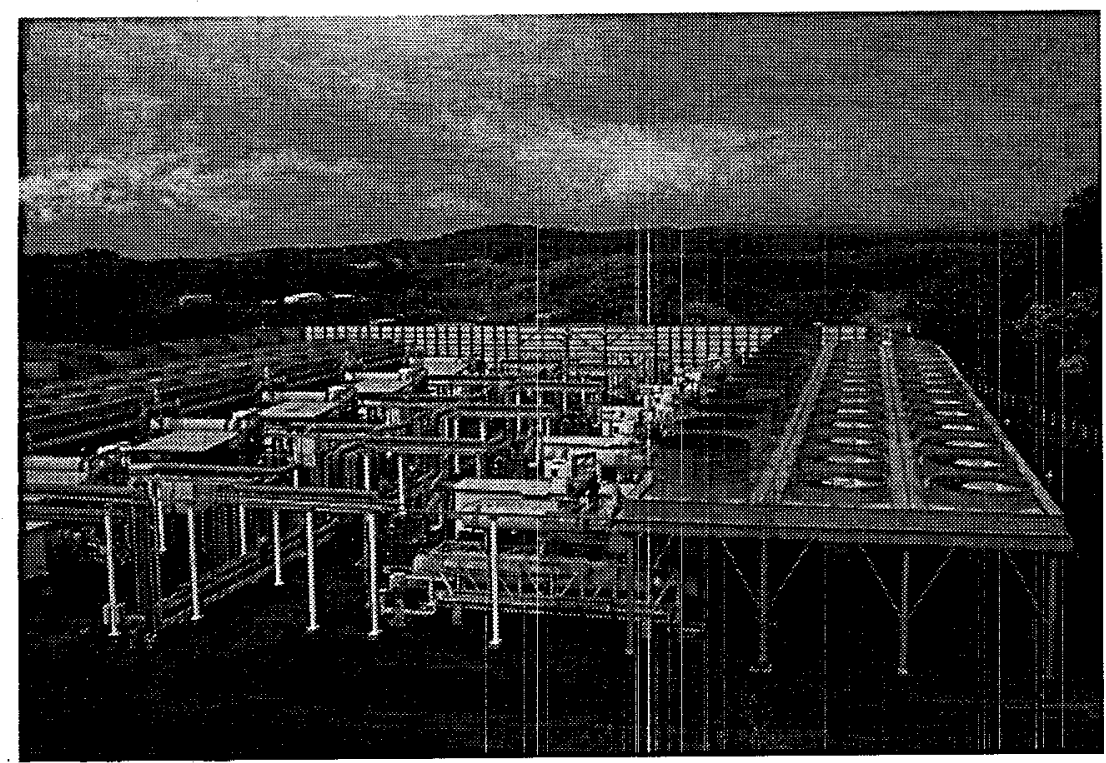

Source: Ormat Technologies, Inc.

Geothermal facilities are often located on lands that have multiple-use capabilities.

Consider a case study at the geothermal facilities of Salton Sea and Imperial Valley in Southern California. At these sites, several aquaculture operations use geothermal water to control the water temperatures, improve fish and fish culture facilities, and extend the fish growth season. In addition, these power plants in the Imperial Valley are surrounded by productive farm land, as highlighted in Figure 21 below. Another geothermal plant, the Mammoth power plant in Northern California, is located only miles from the Mammoth Ski Resort and yet does not detract from the natural beauty of the area. In addition, The Geysers field teems with wildlife and still serves as a prime hunting ground for the individuals and hunting clubs that own much of the land. Finally, a 1995 study found that geothermal resource use can "beneficially influence the state of health of the population and the environment" by reducing deforestation and air emissions. ${ }^{115}$

${ }^{115}$ Krzan, Zbigniew (1995). Environmental Protection of the Tatra, Pieniny, and Gorge Mountains by the Use of Geothermal Energy. WGC. Vol 4. pp.2799-2800. 
Figure 21: Imperial Valley Power Plant Next to Productive Farmland

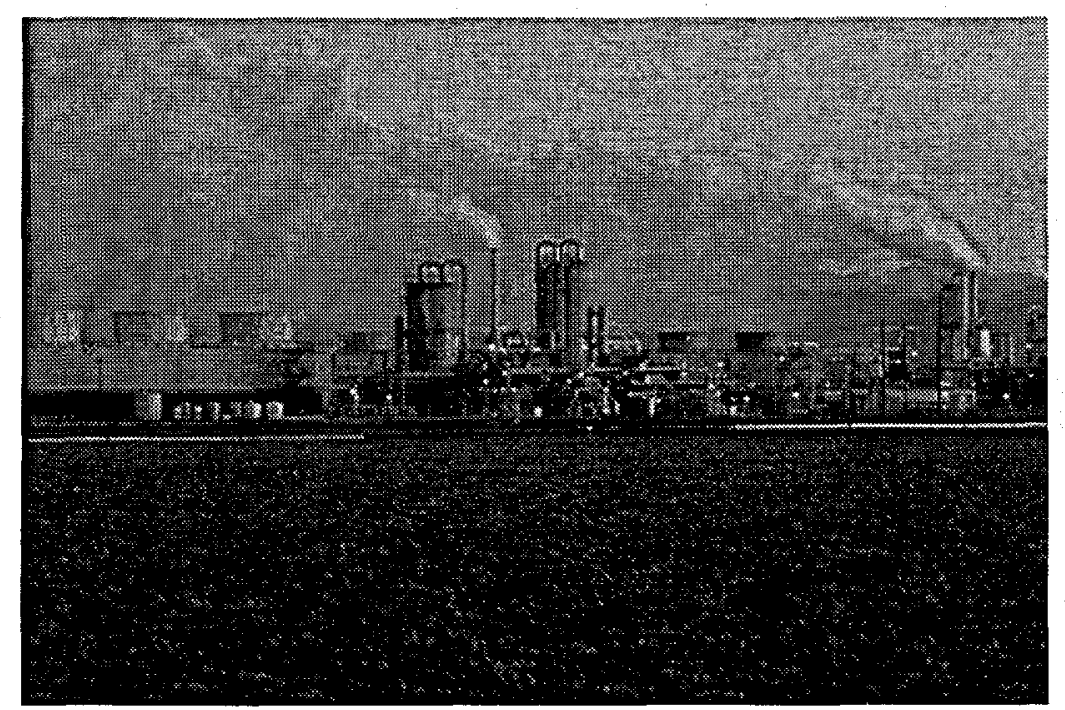

Source: Geothermal Education Office

While some fossil-fuel energy sources, such as coal, use up large swaths of land in the mining of their fuel, geothermal plants minimize the total amount of land used by only building the plant along with the number of well pads needed to support operation. It is important to keep in mind that the land impact of renewable energy development and use is much less damaging than the impact caused by fossil fuel development and use. Coal mining requires the transportation of huge amounts of dirt and rock, sometimes into streams, and causes disruption of water systems through acid drainage, deforestation, and damage to ecosystems. Nuclear facilities require the safe maintenance of huge amounts of radioactive waste. Over 30 years, the period of time commonly used to compare life cycle impacts of different power sources, geothermal uses less land than many other sources, as shown in Figure 22. ${ }^{116}$

\footnotetext{
${ }^{116}$ Brophy, Paul (1997). Environmental Advantages to the Utilization of Geothermal Energy. Renewable Energy, Vol 10:2/3, Table 3, pp. 374.
} 


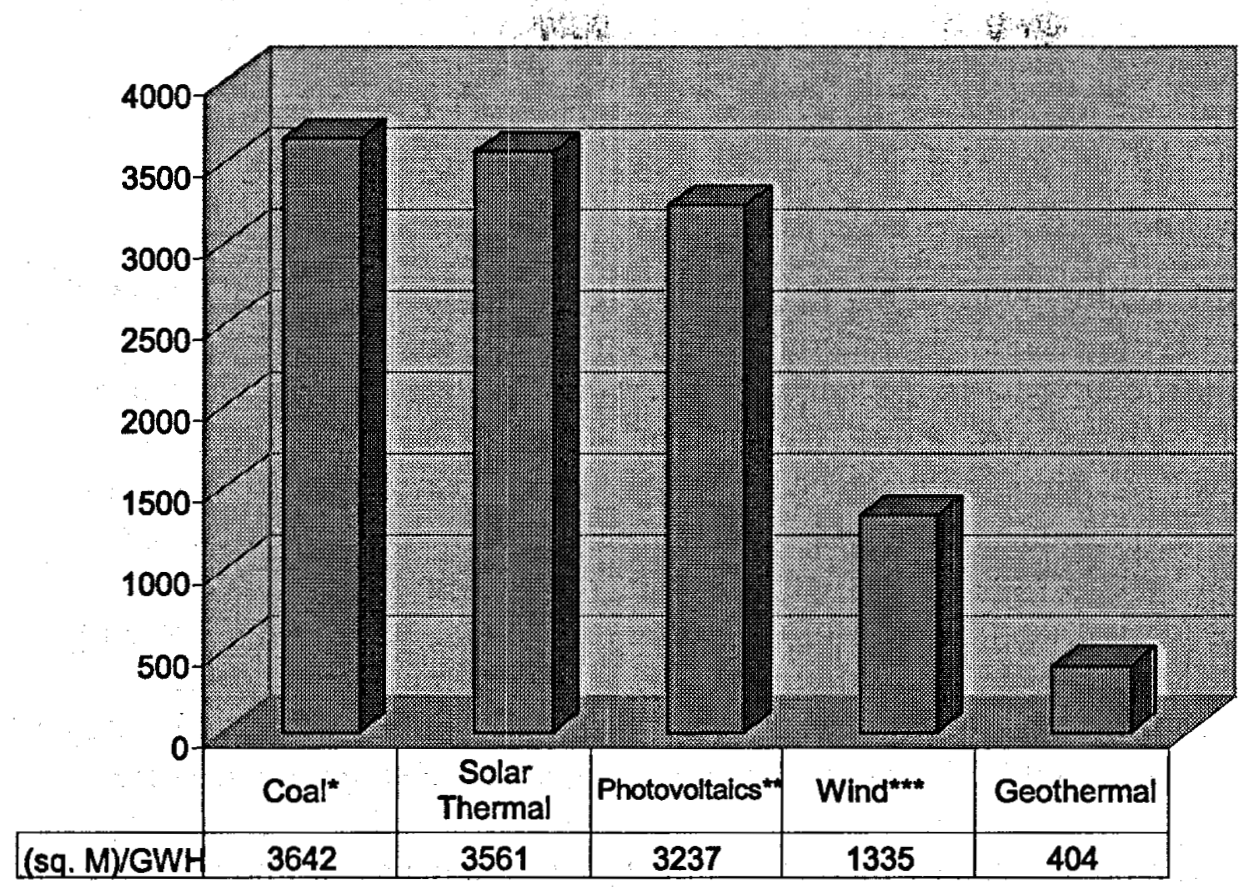

* Includes mining.

**Assumes central station photovoltaic project, not rooftop PV systems.

*** Land actually occupied by turbines and service roads.

Geothermal power plants impose minimal visual impacts on their surroundings when compared to typical fossil-fuel plants. Some of the key visual quality effects related to geothermal development are the presence of steam plumes, night lighting on the wellfield and power plant, and visibility of the transmission line. Fossil fired power plants have all of these visual effects as well. The majority of geothermal visual impacts can be mitigated to reduce their effects. Detailed site planning, facility design, materials selection, revegetation programs, and adjustment to transmission line routing are all key aspects of geothermal operations that can reduce the visual impacts of the facility. Today, many geothermal operators already employ these mitigation techniques to reduce their facilities' visual impact. For example, one large geothermal company reduced the visual impacts of their power plant by painting all of the piping on the plant forest green so that it blended into the surrounding landscape. Additionally, some companies utilize non-specular conductors, which reduce reflection and glare on transmission lines. As the Fourmile Hill EIS found, even within a strictly managed recreational area, "with mitigation, which is an integral part of the project, the proposed project would be consistent with policies in the Klamath National Forest Land Resource Management Plan regarding visual resources."

${ }^{117}$ Fourmile Hill Environmental Impact Statement, 4-182. 
Other visual impacts are only of concern on a temporary basis, such as construction equipment. Construction vehicles, drill rigs, and other heavy equipment would have a negative impact on the visual quality of the area for a limited amount of time.

\section{Subsidence}

Subsidence is most commonly thought of as the slow, downward sinking of the land surface. Other types of ground deformation include upward motion (inflation) and horizontal movements. In some cases, subsidence can damage facilities such as roads, buildings and irrigation systems, or even cause tracts of land to become submerged by nearby bodies of water. Although it can occur naturally, subsidence can also occur as a result of the extraction of subsurface fluids, including groundwater, hydrocarbons, and geothermal fluids. In these cases, a reduction in reservoir pore pressure reduces the support for the reservoir rock itself and for the rock overlying the reservoir, potentially leading to a slow, downward deformation of the land surface. In most areas where subsidence has been attributed to geothermal operations, the region of Earth deformation has been confined to the wellfield area itself, and has not disturbed anything off-site.

While subsidence can be induced by thermal contraction of the reservoir due to extraction and natural recharge, properly placed injection (see injection sections) reduces the potential for subsidence by maintaining reservoir pressures. At fields produced from sedimentary rocks where the porosity and permeability is primarily between rock grains, injection can successfully mitigate for subsidence. At the Heber geothermal field in southern California, for example, injection successfully resolved subsidence. ${ }^{118}$ At The Geysers, where subsidence may be caused more by temperature decline (thermoelastic contraction) than pressure decline (poroelastic contraction), injection is not necessarily an effective mitigation tool for subsidence. However, long-term monitoring at The Geysers demonstrates a very slow rate of subsidence that has no direct environmental impact.

Naturally-occurring subsidence most frequently takes place in areas that are tectonically active such as volcanic regions and fault zones. Subsidence can also typically occur in areas where sedimentary basins are filled with unconsolidated sands, silts, clays and gravels. ${ }^{119}$ Most known geothermal resources are located in areas that are tectonically active, and may experience natural subsidence. For example, subsidence occurs naturally in the Medicine Lake geothermal area of California due to volcanic activity, even though no geothermal development has yet taken place in the region. Because geothermal operations occur at tectonically active sites, it is sometimes difficult to distinguish between induced and naturally occurring subsidence. Subsidence related to geothermal development is more likely in areas where the geothermal reservoir occurs in weak, porous sedimentary or pyroclastic formations. ${ }^{120}$

\footnotetext{
${ }^{118}$ Geothermal Hot Line (Jan. 1996). Subsidence and Uplift at Heber Geothermal Field, California.

${ }^{119}$ Telephone Flat Environmental Impact Statement, 3.1-6.

${ }^{120}$ Fourmile Hill Environmental Impact Statement, 4-7.
} 
In cases where subsidence may be linked to geothermal reservoir pressure decline, injection is an effective mitigating technique. By injecting spent geothermal brines back into the reservoir from which they came, reservoir pressure is stabilized. This approach has helped to maintain the pressure of geothermal reservoirs and can prevent or mitigate for subsidence at geothermal development sites. ${ }^{121}$ In the United States, injection technology is employed at all geothermal projects, minimizing the risk of subsidence.

The EIS written for the Fourmile Hill geothermal project found that "due to the nature of the reservoir and operation methods, minimal subsidence is expected. The impact would be adverse, but not significant." A similar result was found in the EIS for the Telephone Flat geothermal project, where the authors wrote that "there is a remote possibility that land subsidence could occur as a result of shallow groundwater or geothermal fluid production from the subsurface reservoir...the impact is considered less than significant and no mitigation measures are required." Subsidence, which can negatively influence irrigation, has not been detected at the Salton Sea, a site of both large-scale geothermal development and flourishing agricultural practices.

Despite the record of the geothermal industry in the United States, injection technology has not always been utilized in other parts of the world, and therefore subsidence has been a larger issue at some geothermal developments overseas. The most commonly referenced case of major subsidence at a geothermal field is the Wairakei geothermal field in New Zealand. At this field, which has been operating since the late 1950s, geothermal fluids were not routinely injected back into the geothermal reservoir. Although limited injection began in the late 1990's at Wairakei, most subsidence had already occurred at this point. Long-term extraction of fluids without injection resulted in high subsidence rates in some areas near the production field, and a lower rate of subsidence across a much wider area.

Fortunately, the field management practices used at Wairakei have not been followed at geothermal fields elsewhere in the world. In the United States, as well as most other geothermal fields worldwide, injection of spent geothermal brines begins immediately after a plant comes on-line, and continues through the life of the plant. The case of Wairakei has focused undue concern on the issue of subsidence: "the international geothermal community cannot comprehend how or why this continued discharge at Wairakei has gone on for so long. This practice does a disservice to the geothermal industry, which works hard to gain acceptance and can ill afford the squandering of good will by outdated field management practices." 122

${ }^{121}$ Geothermal Hot Line (Jan. 1996). Subsidence and Uplift at Heber Geothermal Field, California.

${ }^{122}$ Ann Robertson-Tait, Senior Geologist, GeothermEx, Inc. (2004). Statement of Evidence, submission to applications by Contact Energy Limited for resource consents for the use and disposal of geothermal fluid from the Wairakei geothermal system. 


\section{Induced Seismicity}

Earthquake activity, or seismicity, is generally caused by displacement across active faults in tectonically active zones. An earthquake occurs when a body of rock is ruptured and radiates seismic waves that shake the ground. Although it typically occurs naturally, seismicity has at times been induced by human activity, including the development of geothermal fields, through both production and injection operations. In these cases, the resulting seismicity has been low-magnitude events known as "microearthquakes." Earthquakes with Richter magnitudes below 2 or 3 , which are generally not felt by humans, are called microearthquakes. These microearthquakes sometimes occur when geothermal fluids are injected back into the system, and are centered on the injection site. The microearthquakes sometimes associated with geothermal development are not considered to be a hazard to the geothermal power plants or the surrounding communities, and will usually go unnoticed unless sensitive seismometers are located nearby. As the authors of the final EIS for the Fourmile Hill geothermal project reported, "geothermal production areas have experienced increased seismic activity in the magnitude range of 1 to 3 on the Richter scale as development proceeded. These event magnitudes are too low to be felt by humans and are not of concern to the safe operation of the project." However, around some geothermal fields, particularly The Geysers, there have been complaints about increased seismicity in nearby communities.

Much like subsidence discussed in the previous section, seismicity typically takes place in areas with high levels of tectonic activity, such as volcanic regions and fault zones. Because geothermal operations usually take place in areas that are also tectonically active, it is often difficult to distinguish between geothermal-induced and naturally occurring events. Many regions where geothermal development has occurred or has been planned are known as areas with high levels of fault activity. For example, the fault activity associated with the Cascade volcanoes and the Modoc Plateau had the potential to produce surface rupture and strong ground shaking in the Klamath National Forest area prior to any geothermal development in the region. ${ }^{123}$ Indeed, several earthquakes have plagued the region, including a 4.6 quake fifteen miles southwest of the proposed geothermal site in 1978, a swarm of low-magnitude quakes fourteen miles west of the proposed site in 1981, and several quakes near Medicine Lake in 1989, approximately two miles southeast of the proposed plant. ${ }^{124}$ Virtually all the regions of California where geothermal development has occurred are located in what has long been known as "earthquake country" even prior to geothermal development. These regions frequently experience earthquakes of various magnitudes, though few are felt by humans.

\footnotetext{
${ }^{123}$ Fourmile Hill Environmental Impact Statement, 3-6.

${ }^{124}$ Ibid.
} 
Seismic Monitoring ${ }^{125}$

Experts at The Geysers agree that geothermal field development and expansion has resulted in seismic activity, though many of these induced microearthquakes require sensitive instrumentation to be detected. ${ }^{126}$ Since 1980 , two to three events of magnitude $\geq 4.0$ per decade, and an average of about 18 events of magnitude $\geq 3.0$ per year, have occurred in the region. ${ }^{127}$ As a result of a project EIR to bring in supplemental water from Lake County for injection at The Geysers, a Seismic Monitoring Committee (SMAC) was established to provide an open forum for concerned individuals and parties, even though the EIR determined that a geothermal facility would induce less than significant increases in seismic activity.

While the largest earthquake ever detected in The Geysers area measured 4.6 on the Richter scale, seismic activity elsewhere in the region can be much more dangerous. In 1969, Santa Rosa, California, 40 miles from the geothermal site, experienced an earthquake of magnitude 5.7, and the USGS estimates that the Healdsburg-Rodgers Creek Fault is likely to experience an earthquake of Richter magnitude 6.5 within 30 years. The USGS monitors the region but does not treat the seismic activity at The Geysers as a significant concern compared to the larger-magnitude seismicity in the region, and therefore does not specifically focus monitoring efforts on The Geysers field. ${ }^{13}$ Calpine, which operates most of The Geysers power plants, monitors field-wide seismicity more closely. Both the USGS and the Calpine data sets are made available to the public and are used for research purposes.

\section{Landslides}

The extent to which geothermal development induces landslides is unclear, as landslides, which occur naturally in certain areas of geothermal activity such as volcanic zones, are produced by a combination of events or circumstances rather than by any single specific action. While field construction operations can "trigger" landslides, local geological preconditions must already exist in order for landslides to occur. Though landslides are rare, when they occur they are small enough to be confined entirely to the wellfield area of a geothermal facility. Geothermal areas with landslide hazards can be properly managed through detailed hazard mapping, groundwater assessment, and deformation monitoring, among other management techniques. Because landslides always present warning signs, such techniques ensure that landslides can be avoided on geothermal lands. ${ }^{128}$

\footnotetext{
${ }^{125}$ Telephone Flat Environmental Impact Statement, 3.1-5.

${ }^{126}$ Personal Correspondence with geophysicist Mitch Stark, Calpine SMAC participant. September 27, 2004.

${ }^{127}$ Ibid

${ }^{128}$ Voight, B. (1992) Causes of Landslides: Conventional Factors Special Considerations for Geothermal Sites and Volcanic Regions. GRC Transactions:16. pp. 529-533.
} 


\section{Geysers, Fumaroles, and Geothermal Resources}

Geothermal resources are often discovered under certain land features such as geysers, fumaroles, hot springs, mud pools, steaming ground, sinter, and travertine. Geysers are hot springs where hot water, steam, or gas periodically erupts, while fumaroles vent gas and steam. The word "geyser" derives from the Icelandic word, "geysir," which means, "the gusher." The pictures below highlight some of these surface features.

Figure 23: Geothermal Surface Features

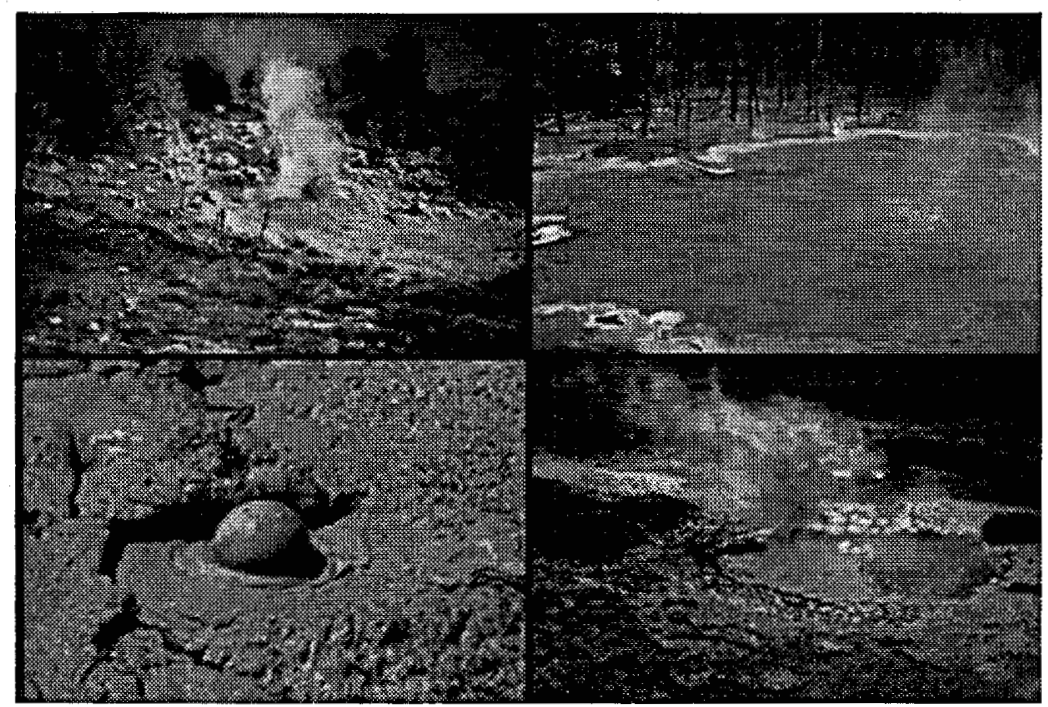

Source: Geothermal Education Office

Some individuals have expressed concern that such land features will be drastically altered or destroyed as a result of geothermal development. In some cases, both during past geothermal development and geothermal development overseas, it is true that land features have been altered by geothermal development. However, through the evolution of geothermal development, developers have come to understand the best management practices that reduce surface feature impact, and have employed preventative mitigation measures that reduce potential impact to surface features before they arise. In addition, federal law requires monitoring programs for significant surface features, and forbids geothermal development in areas where surface features may be adversely affected, including Yellowstone National Park. The current status of geothermal development shows that little alteration of land features has occurred in recent years as a result of sound geothermal management practices and federal law compliance. 
Myth 5: Natural Geothermal Surface Features Are Used During Geothermal Development.

Truth: While surface features such as geysers or fumaroles are typically useful in identifying the locations of geothermal resources, these features are not used during geothermal development. Instead, drilling that extracts geothermal resources takes place close to these features. In fact, it is impossible to extract geothermal resources, for the purpose of large scale utility development, from geothermal surface features themselves. Further, while almost all geothermal resources currently developed for electricity production are located in the vicinity of natural geothermal surface features, much of the undeveloped geothermal resource base may be found deep under the Earth without any corresponding surface thermal manifestations. Whether or not geothermal fluids will manifest on the surface depends on the natural "plumbing" underground which may or may not connect geothermal resources to the surface of the Earth. At Medicine Lake in California, for example, there is only a single, very weak thermal manifestation at the surface, yet extensive geothermal resources have been identified underground. Resources that are more difficult to identify, without surface expression, are less likely to be explored given the limitations of today's technology. While the size and extent of geothermal surface features can be a rough guide to the size of a geothermal resource, a considerable amount of uncertainty still exists. 
Myth 6: Current Geothermal Development Alters Geothermal Land Features

Truth: Although all geothermal development can potentially disrupt land features, proper project management reduces or altogether eliminates land alteration. U.S. law prohibits geothermal development in sensitive areas as a precautionary measure. Geothermal development is forbidden in and around Yellowstone National Park, for example, in order to protect the famous geysers in the park. The geothermal development of the 1970s and early 1980 s, which sometimes altered surrounding geysers, fumaroles and other surface features, prompted U.S. regulation, including the Steam Act and other national laws, which protect national parks and their significant thermal features from adverse impacts. Geothermal developers make every effort to protect natural surface features, both by strictly adhering to federal laws, and also by employing their own independent management techniques. It is important to note, in addition, that geysers and fumaroles can both arise and disappear naturally, without any human interference. In some developed geothermal fields, it is difficult to distinguish such natural ephemeral behavior from changes induced by geothermal or potable water resource development. Over time, pressure increases in hot springs can cause geysers to erupt continuously and become narrower in shape. If increased pressure causes a geyser to explode, it often resumes its previous shape and pressure as a hot spring. Moreover, the fluid pathways that feed a surface manifestation can be altered due to natural processes such as deposition and dissolution of minerals, interaction with meteoric water, and seismicity. Any of these factors can cause dramatic changes in the location, appearance, or existence of manifestation. At times, weather patterns such as droughts have been shown to affect the activity of geothermal surface features. So both natural phenomenon and geothermal development have the potential to-but do not always-alter geothermal land features.

\section{$\underline{\text { XV. Impact on Wildlife and Vegetation }}$}

Geothermal development poses only minimal impact to wildlife and vegetation in the surrounding area when compared with alternatives such as coal. It should be noted that geothermal facilities must sometimes be built in more sensitive areas than coal plants. However, increased sensitivity leads to increased mitigation and surveillance in these areas. Before geothermal construction can even begin, an environmental review may be required to categorize potential effects upon plants and animals. In preparation for Telephone Flat construction, for example, a biological study area of $1 / 4$ mile beyond the perimeter of the project wellfield took inventory of vegetation and species, noting habitat requirements and suitability. ${ }^{129}$ While any disruption of land that results from power plant construction has the potential to disturb habitat, geothermal plants, like any type of power plant, must comply with a host of regulations that protect areas set for

${ }^{129}$ Telephone Flat Environmental Impact Statement, 3.3-33 
development, including the Endangered Species Act, the National Forest Management Act, and several other acts that vary from state to state.

Geothermal plants are designed to minimize the potential effect upon wildlife and vegetation: pipes are insulated to prevent thermal losses, power plants are fenced in so as to prevent wildlife access, spill containment systems with potential to hold 150 percent of the potential maximum spill are put in place, and areas with high concentrations of wildlife or vegetation specific to an area are avoided. Because geothermal plants avoid much of the additional disruption caused by mining coal and building roads to transport it, the construction of a geothermal plant reduces the overall impact on wildlife and vegetation species from energy production. A typical $500 \mathrm{MW}$ coal plant, for example, can disrupt 21 million fish eggs, fish larvae, and juvenile fish from water usage alone during normal operation, as the 2.2 billion gallons of water required each year to create steam for turbine generation is extracted from nearby water bodies rich with fish species. ${ }^{130}$ Many species' habitats are restricted by road construction or eliminated altogether by mining activities related to fossil fuel production.

${ }^{130}$ UCS (2002). Environmental Impacts of Coal. Retrieved October 19, 2004, from http://www.ucsusa.org/CoalvsWind/c02b.html. 


\section{Summary and Conclusion}

\section{The Big Picture: Electricity Production and its Consequences}

Despite improvements in coal, natural gas, and oil power plant technology, fossil fuel combustion continues to produce more air pollution than any other single source. ${ }^{131}$ Power plants contribute close to 60 percent of U.S. water pollution. ${ }^{132}$

The EPA, in its discussion of power plant impacts, notes that "fossil fuel-fired power plants are responsible for 67 percent of the nation's sulfur dioxide emissions, 23 percent of nitrogen oxide emissions, and 40 percent of man-made carbon dioxide emissions." 133

These pollutants have been widely documented to cause a host of environmental and health problems, including smog formation, respiratory attacks in children and seniors, acid rain that damages water bodies and forests, nitrogen emissions that lead to dead zones of aquatic life, mercury contamination of lakes and streams that has led 40 states to issue fish mercury advisories, and carbon dioxide-driven climate change that results in destructive floods, droughts, heat waves, intense storms, and climate-related infectious disease. $^{134}$

The EPA highlights the increasingly important role of green power in contributing to the clean air goals of the U.S. According to a number of EPA studies, if all states were to implement "cost-effective energy efficiency and clean energy policies, the expected growth in demand for electricity could be cut in half by 2025 , providing billions of dollars in customer savings, contributing to lower prices for natural gas, and substantially reducing greenhouse gas emissions. ${ }^{135}$,

Although green power pollutes significantly less than fossil fuel sources, it is important to note that all power generation impacts the environment, regardless of whether electricity is derived from the combustion of fossil fuel or renewable sources. Impacts such as land use, for example, cannot be avoided no matter what level of mitigation is employed. The

${ }^{131}$ U.S. EPA (2004). How Does Energy Use Affect the Environment? Retrieved September 29, 2004, from http://www.epa.gov/cleanenergy/impacts.htm

${ }_{132}$ National Aerodynamics and Space Administration [NASA] Glenn Research Center. Pollution.

Retrieved December 1, 2004, from http://www.grc.nasa.gov/WWW/K-12/fenlewis/Pollution.html

${ }^{133}$ U.S. EPA (2004). How Does Energy Use Affect the Environment? Retrieved September 29, 2004, from http://www.epa.gov/cleanenergy/impacts.htm

${ }^{134}$ Hawkins, David G., Director, Air \& Energy Programs., Natural Resources Defense Council [NRDC]. (March 21, 2001). "Harmonizing the Clean Air Act with Our Nation's Energy Policy." U.S. Senate

Hearing Testimony before the Subcommittee on Clean Air, Wetlands, Private Property and Nuclear Safety, Committee on Environment and Public Works Retrieved November 11, 2004, from

http://epw.senate.gov/107th/haw 0321.htm.

${ }_{135}$ U.S. EPA. NREL (2004). EPA-State Energy Efficiency and Renewable Energy Projects. Retrieved March 8, 2005, from http://www.epa.gov/cleanenergy/pdf/eere factsheet.pdf. 
goal, instead of eliminating all impacts, should be to minimize impacts. Because we cannot feasibly shut down all electricity producers, we must look to alternative sources such as geothermal energy.

\section{Summarized Environmental Benefits of Geothermal Energy}

In light of the inevitable impact and use of energy, specifically electricity, in the United States, it is important to consider the environmental benefits of geothermal energy, especially when compared to more common energy sources such as fossil fuels. Although geothermal provides environmentally sound electricity to millions of Americans, it supplies only a small percentage of total domestic electricity. In highlighting some of the most important environmental benefits of geothermal energy, the bullets below support the expanded development of geothermal power production.

- Geothermal energy is reliable. Because geothermal resources are available 24 hours a day regardless of changing weather, geothermal energy is as reliable as any fossil fuel facility. Geothermal is a renewable energy technology that can offer baseload or intermediate power, is dispatchable, and can achieve high capacity factors. Geothermal represents a plentiful resource that has not been utilized to its full potential. As an additional bonus, geothermal energy does not rely upon energy imports. Geothermal is an indigenous source of energy.

- Geothermal energy is renewable. Geothermal resources are sustainable because of the heat from the earth and water injection, and thus will not diminish like fossil fuel reserves. As time progresses and technology improves, our ability to extract geothermal resources with ease will increase, not decrease.

- Geothermal energy produces minimal air emissions and offsets the high air emissions of fossil fuel-fired power plants. Emissions of nitrous oxide, hydrogen sulfide, sulfur dioxide, particulate matter, and carbon dioxide are extremely low, especially when compared to fossil fuel emissions. The binary geothermal plant, which currently represents around 15 percent of all geothermal plant capacity, along with the flash/binary plant, produce nearly zero air emissions. Lake County, California, downwind of The Geysers, has met all federal and state ambient air quality standards for seventeen years. At The Geysers, air quality has even improved as a result of geothermal development because hydrogen sulfide, which would ordinarily be released naturally into the atmosphere by hot springs and fumaroles, instead now passes through an abatement system that reduces hydrogen sulfide emissions by 99.9 percent.

- Geothermal energy can offset other environmental impacts. Wastewater that would otherwise damage surface waters is being used to recharge The Geysers geothermal system and irrigate local land. In addition, electricity generation from geothermal resources eliminates the mining, processing and transporting required 
for electricity generation from fossil fuel resources. Finally, research into the extraction of minerals from geothermal fluids is showing great promise. Use of extraction technology would allow for the production of minerals without the environmental impacts of mining.

- Geothermal energy is combustion free. Unlike fossil fuel power plants, no smoke is emitted from geothermal power plants, because no burning takes place: only steam is emitted from geothermal facilities.

- Geothermal energy minimally impacts land. According to the U.S. Department of Energy, geothermal energy uses less land than other energy sources, both fossil fuel and renewable. No transportation of geothermal resources is necessary, because the resource is tapped directly at its source.

- Geothermal energy is competitive with other energy technologies when environmental costs are considered. A 1995 study estimates that costs of power generation would increase 17 percent for natural gas and 25 percent for coal if environmental costs were included. ${ }^{136}$ These costs include land degradation, potentially toxic emissions, forced extinction and destruction of animals and plants, and health impacts to humans.

\section{$\underline{\text { XVIII. Conclusion }}$}

Abundant geothermal resources throughout the nation can provide an environmentally friendly source of energy. Data compiled from a variety of sources point to geothermal energy as an environmental option for new power generation that is far better than other energy sources such as fossil fuels. In addition, geothermal remains as environmentally friendly as most other renewable sources, while simultaneously offering reliability and a source of baseload power that is unique among most other renewable options available. The Department of Energy, along with several scientific laboratories, conducts research on a regular basis to improve the already minimal environmental impacts of geothermal energy and to decrease the associated costs.

While currently used at only a fraction of its potential, geothermal energy can substantially contribute to the energy needs of the twenty-first century. With increased federal research and development funding in conjunction with supportive renewable energy policies, the Union of Concerned Scientists (UCS) estimates that renewable sources of energy could meet 20 percent of the nation's electricity needs by 2020 , with geothermal contributing 19 percent of the overall renewable contribution (just under 4 percent of total domestic electricity needs). ${ }^{137}$ If this UCS geothermal projection can be

\footnotetext{
${ }^{136}$ Haberle and Flynn (1995). Comparative Economics and Benefits of Electricity Produced from Geothermal Resources in the State of Nevada. Univ. of Nevada, Las Vegas.

${ }^{137}$ UCS (October 2001). Clean Energy Blueprint. Retrieved October 18, 2004, from http://www.ucsusa.org/documents/blueprint.pdf.
} 
achieved, geothermal development-in the United States alone-will increase by almost thirteen times its current use. As geothermal energy production is refined and expanded, the benefits continue to grow.

With continued technological development, geothermal can be expanded from the western states to all of the United States, and the already negligible environmental geothermal impacts can be reduced to nearly zero. Geothermal energy can provide the clean, reliable, and plentiful renewable energy resource for our nation and for the world. 


\section{Glossary $^{138}$}

Acid Rain: Also called acid precipitation or acid deposition, acid rain is precipitation containing harmful amounts of nitric and sulfuric acids formed primarily by nitrogen oxides and sulfur oxides released into the atmosphere when fossil fuels are burned. It can be wet precipitation (rain, snow, or fog) or dry precipitation (absorbed gaseous and particulate matter, aerosol particles or dust). Acid rain has a pH below 5.6. Normal rain has a $\mathrm{pH}$ of about 5.6, which is slightly acidic. The term $\mathrm{pH}$ is a measure of acidity or alkalinity and ranges from 0 to 14 . $\mathrm{A} \mathrm{pH}$ measurement of 7 is regarded as neutral. Measurements below 7 indicate increased acidity, while those above indicate increased alkalinity.

Air Pollution: Unwanted particles, mist or gases put into the atmosphere as a result of motor vehicle exhaust, the operation of industrial facilities or other human activity.

Ambient: Natural condition of the environment at any given time.

Anthropogenic: ${ }^{139}$ Caused by human action, such as changes in vegetation, an ecosystem, or an entire landscape.

Aquaculture: ${ }^{140}$ farming of organisms that live in water, such as fish, shellfish, and algae.

Baseload: The lowest level of power production needs during a season or year.

Baseload Plants: Electricity-generating units that are operated to meet the constant or minimum load on the system. The cost of energy from such units is usually the lowest available to the system.

Binary-Cycle Plant: A geothermal electricity generating plant employing a closed-loop heat exchange system in which the heat of the geothermal fluid (the "primary fluid") is transferred to a lower-boiling-point fluid (the "secondary" or "working" fluid), which is thereby vaporized and used to drive a turbine/generator set.

Biomass: Energy resources derived from organic matter. These include wood, agricultural waste and other living-cell material that can be burned to produce heat energy. They also include algae, sewage and other organic substances that may be used to make energy through chemical processes.

Bituminous Coal: A dense coal, usually black, sometimes dark brown, often with well-defined bands of bright and dull material, used primarily as fuel in steam-electric power generation, with substantial quantities also used for heat and power applications in manufacturing and to make coke. Bituminous coal is the most abundant coal in active U.S. mining regions. Its moisture

\footnotetext{
${ }^{138}$ All terms from Energy Information Administration [ELA] (2002). Glossary of Electricity Terms Retrieved December 13, 2004, from http://www.eia.doe.gov/cneaf/electricity/epavl/glossary.html, California Energy Commission [CEC] (2004). Retrieved December 13, 2004, from http://www.energy.ca.gov/glossaryl. Glossary of Energy Terms. Retrieved January 7, 2005, or U.S. DOE Energy Efficiency and Renewable Energy Geothermal Technologies Program. Geothermal Glossary. Retrieved April 14, 2005, from http://www.eere.energy.gov/geothermal/glossary.html, unless otherwise noted.

${ }^{139}$ Source: USGS

${ }^{140}$ Ibid.
} 
content usually is less then 20 percent. The heat content of bituminous coal ranges from 21 to 30 million Btu per ton on a moist, mineral-matter-free basis. The heat content of bituminous coal consumed in the United States averages 24 million Btu per ton, on the as-received basis (i.e., containing both inherent moisture and mineral matter).

Brine: A geothermal solution containing appreciable amounts of sodium chloride or other salts.

Butane: A hydrocarbon gas found in the Earth along with natural gas and oil. Butane turns into a liquid when put under pressure. It is sold as bottled gas. It is used to run heaters, stoves and motors, and to help make petrochemicals.

Btu (British Thermal Unit): A standard unit for measuring the quantity of heat energy equal to the quantity of heat required to raise the temperature of 1 pound of water by 1 degree Fahrenheit.

Capacity: The amount of electric power delivered or required for which a generator, turbine, transformer, transmission circuit, station, or system is rated by the manufacturer.

Capacity Factor: A percentage that tells how much of a power plant's capacity is used over time. For example, typical plant capacity factors range as high as 80 percent for geothermal and $\mathbf{7 0}$ percent for cogeneration.

Capacity, Installed (or Nameplate): The total manufacturer-rated capacities of equipment such as turbines, generators, condensers, transformers, and other system components.

Carbon Dioxide: A colorless, odorless, non-poisonous gas that is a normal part of the air. Carbon dioxide, also called $\mathrm{CO}_{2}$, is exhaled by humans and animals and is absorbed by green growing things and by the sea.

Carcinogens: Potential cancer-causing agents in the environment. They include among others: industrial chemical compounds found in food additives, pesticides and fertilizers, drugs, toy, household cleaners, toiletries and paints. Naturally occurring ultraviolet solar radiation is also a carcinogen.

Coal: A readily combustible black or brownish-black rock whose composition, including inherent moisture, consists of more than 50 percent by weight and more than 70 percent by volume of carbonaceous material. It is formed from plant remains that have been compacted, hardened, chemically altered, and metamorphosed by heat and pressure over geologic time.

Combined Cycle: An electric generating technology in which electricity is produced from otherwise lost waste heat exiting from one or more gas (combustion) turbines. The exiting heat is routed to a conventional boiler or to a heat recovery steam generator for utilization by a steam turbine in the production of electricity. This process increases the efficiency of the electric generating unit.

Consumption (Fuel): The amount of fuel used for gross generation, providing standby service, start-up and/or flame stabilization.

Cooling Tower: A structure in which heat is removed from hot condensate.

Condensate: Water formed by condensation of steam. 
Cost: The amount paid to acquire resources, such as plant and equipment, fuel, or labor services.

Crust: Earth's outer layer of rock. Also called the lithosphere.

Demand (Utility): The level at which electricity or natural gas is delivered to users at a given point in time. Electric demand is expressed in kilowatts.

(U.S.) Department of Energy (U.S. DOE): The federal department established by the Department of Energy Organization Act to consolidate the major federal energy functions into one cabinet-level department that would formulate a comprehensive, balanced national energy policy. DOE's main headquarters are in Washington, D.C.

Distillate Fuel: A general classification for the petroleum fractions produced in conventional distillation operations. Included are products known as No. 1, No. 2, and No. 4 fuel oils and No. 1, No. 2, and No. 4 diesel fuels. Used primarily for space heating, on- and off-highway diesel engine fuel (including railroad engine fuel and fuel for agricultural machinery), and electric power generation.

Direct Use: Use of geothermal heat without first converting it to electricity, such as for space heating and cooling, food preparation, industrial processes, etc.

Drift: ${ }^{141}$ Drift droplets are any water droplets and dissolved and suspended solids that are entrained in the air and emitted from the cooling tower stack.

Drift Eliminator: ${ }^{142}$ Drift eliminators reduce the amount of drift in the exiting air flow. Drift droplets can be reduced to less than $0.1 \%$ by effective use of an eliminator.

Drilling: Boring into the Earth to access geothermal resources, usually with oil and gas drilling equipment that has been modified to meet geothermal requirements.

Dispatch: The operating control of an integrated electric system to: Assign generation to specific generating plants and other sources of supply to effect the most reliable and economical supply as the total of the significant area loads rises or falls. Control operations and maintenance of highvoltage lines, substations and equipment, including administration of safety procedures. Operate the interconnection. Schedule energy transactions with other interconnected electric utilities.

Dry Steam: Very hot steam that doesn't occur with liquid.

\section{Effluent: treated wastewater}

Efficiency: The ratio of the useful energy delivered by a dynamic system (such as a machine, engine, or motor) to the energy supplied to it over the same period or cycle of operation. The ratio is usually determined under specific test conditions.

Emissions Standard: The maximum amount of a pollutant legally permitted to be discharged from a single source.

${ }^{141}$ Source: California Government's Bay Area Air Quality Management District (BAAQMD)

${ }^{142}$ Ibid. 
Energy: The capacity for doing work as measured by the capability of doing work (potential energy) or the conversion of this capability to motion (kinetic energy). Energy has several forms, some of which are easily convertible and can be changed to another form useful for work. Most of the world's convertible energy comes from fossil fuels that are burned to produce heat that is then used as a transfer medium to mechanical or other means in order to accomplish tasks.

Electrical energy is usually measured in kilowatt-hours, while heat energy is usually measured in British thermal units.

Energy Efficiency: Refers to programs that are aimed at reducing the energy used by specific end-use devices and systems, typically without affecting the services provided. These programs reduce overall electricity consumption (reported in megawatt-hours), often without explicit consideration for the timing of program-induced savings. Such savings are generally achieved by substituting technically more advanced equipment to produce the same level of end-use services (e.g. lighting, heating, motor drive) with less electricity. Examples include high-efficiency appliances, efficient lighting programs, high-efficiency heating, ventilating and air conditioning (HVAC) systems or control modifications, efficient building design, advanced electric motor drives, and heat recovery systems.

Environmental Protection Agency: A federal agency created in 1970 to permit coordinated governmental action for protection of the environment by systematic abatement and control of pollution through integration or research, monitoring, standards setting and enforcement activities.

Energy Source: The primary source that provides the power that is converted to electricity through chemical, mechanical, or other means. Energy sources include coal, petroleum and petroleum products, gas, water, uranium, wind, sunlight, geothermal, and other sources.

EPACT: The Energy Policy Act of 1992 addresses a wide variety of energy issues. The legislation creates a new class of power generators, exempt wholesale generators, that are exempt from the provisions of the Public Holding Company Act of 1935 and grants the authority to the Federal Energy Regulatory Commission to order and condition access by eligible parties to the interconnected transmission grid.

Evaporite: ${ }^{143}$ a sedimentary rock that originates by evaporation of seawater in an enclosed basin

Facility: An existing or planned location or site at which prime movers, electric generators, and/or equipment for converting mechanical, chemical, and/or nuclear energy into electric energy are situated, or will be situated. A facility may contain more than one generator of either the same or different prime mover type. For a cogenerator, the facility includes the industrial or commercial process.

Fault: A fracture or fracture zone in the Earth's crust along which slippage of adjacent Earth material has occurred at some time.

Flash Steam: Steam produced when the pressure on a geothermal liquid is reduced. Also called flashing.

${ }^{143}$ Source: Merriam-Webster dictionary 
Flue Gas Desulphurization Unit (Scrubber): Equipment used to remove sulfur oxides from the combustion gases of a boiler plant before discharge to the atmosphere. Chemicals, such as lime, are used as the scrubbing media.

Fly Ash: Particulate matter from coal ash in which the particle diameter is less than $1 \times 10^{-4}$ meter. This is removed from the flue gas using flue gas particulate collectors such as fabric filters and electrostatic precipitators.

Fossil Fuel: Any naturally occurring organic fuel, such as petroleum, coal, and natural gas.

Fossil-Fuel Plant: A plant using coal, petroleum, or gas as its source of energy.

Fuel: Any substance that can be burned to produce heat; also, materials that can be fissioned in a chain reaction to produce heat.

Fumarole: A vent or hole in the Earth's surface, usually in a volcanic region, from which steam, gaseous vapors, or hot gases issue.

Gas: A fuel burned under boilers and by internal combustion engines for electric generation. These include natural, manufactured and waste gas.

Generator: A machine that converts mechanical energy into electrical energy.

Geology: Study of the planet Earth, its composition, structure, natural processes, and history.

Geothermal: Of or relating to the Earth's interior heat.

Geothermal Energy: Natural heat from within the Earth, captured for production of electric power, space heating or industrial steam.

Geothermal Heat Pumps: Devices that take advantage of the relatively constant temperature of the Earth's interior, using it as a source and sink of heat for both heating and cooling. When cooling, heat is extracted from the space and dissipated into the Earth; when heating, heat is extracted from the Earth and pumped into the space.

Geothermal Plant: A plant in which the prime mover is a steam turbine. The turbine is driven either by steam produced from hot water or by natural steam that derives its energy from heat found in rocks or fluids at various depths beneath the surface of the Earth. The energy is extracted by drilling and/or pumping.

Geothermal Steam: Steam drawn from deep within the Earth.

Generation (Electricity): The process of producing electric energy by transforming other forms of energy; also, the amount of electric energy produced, expressed in watt-hours (Wh). 
Geyser: A spring that shoots jets of hot water and steam into the air.

Geysers, The (note: "The" of "The Geysers" is always capitalized): A large geothermal steam field located north of San Francisco.

Gigawatt (GW): One billion watts.

Gigawatt-hour (GWh): One billion watt-hours.

Greenhouse Effect: The increasing mean global surface temperature of the Earth caused by gases in the atmosphere (including carbon dioxide, methane, nitrous oxide, ozone, and chlorofluorocarbon). The greenhouse effect allows solar radiation to penetrate but absorbs the infrared radiation returning to space.

Grid: The layout of an electrical distribution system.

Heat Exchanger: A device for transferring thermal energy from one fluid to another.

\section{Heat Pumps: See Geothermal Heat Pumps}

Hot Dry Rock: A geothermal resource created when impermeable, subsurface rock structures, typically granite rock 15,000 feet or more below the Earth's surface, are heated by geothermal energy. The resource is being investigated as a source of energy production.

Hydroelectric Plant: A plant in which the turbine generators are driven by falling water.

Hydrothermal Resource: Underground systems of hot water and/or steam.

Injection: The process of returning spent geothermal fluids to the subsurface. Sometimes referred to as reinjection.

Kilowatt (kW): One thousand watts.

Kilowatt-hour (kWh): One thousand watt-hours.

Known Geothermal Resource Area: A region identified by the U.S. Geological Survey as containing geothermal resources:

Leaching: ${ }^{144}$ The removal of readily soluble components, such as chlorides, sulfates, organic matter, and carbonates, from soil by percolating water. The remaining upper layer of leached soil becomes increasingly acidic and deficient in plant nutrients.

Lignite: The lowest rank of coal, often referred to as brown coal, used almost exclusively as fuel for steam-electric power generation. It is brownish-black and has a high inherent moisture content, sometimes as high as 45 percent. The heat content of lignite ranges from 9 to 17 million Btu per ton on a moist, mineral-matter-free basis. The heat content of lignite consumed in the

${ }^{144}$ Source: USGS 
United States averages 13 million Btu per ton, on the as-received basis (i.e., containing both inherent moisture and mineral matter).

Load (Electric): The amount of electric power delivered or required at any specific point or points on a system. The requirement originates at the energy-consuming equipment of the consumers.

Magma: The molten rock and elements that lie below the Earth's crust. The heat energy can approach 1,000 degrees Fahrenheit and is generated directly from a shallow molten magma resource and stored in adjacent rock structures. To extract energy from magma resources requires drilling near or directly into a magma chamber and circulating water down the well in a convection- type system. California has two areas that may be magma resource sites: the MonoLong Valley Caldera and Coso Hot Springs Known Geothermal Resource Areas.

Mantle: The Earth's inner layer of molten rock, lying beneath the Earth's crust and above the Earth's core of liquid iron and nickel.

Megawatt (MW): One thousand kilowatts $(1,000 \mathrm{~kW})$ or one million $(1,000,000)$ watts. One megawatt is enough energy to power 1,000 average homes.

Megawatt-hour (MWh): One million watt-hours.

Methane: A light hydrocarbon that is the main component of natural gas and marsh gas. It is the product of the anaerobic decomposition of organic matter, enteric fermentation in animals and is one of the greenhouse gases. Chemical formula is $\mathrm{CH} 4$.

Micron: A unit of length equal to one-millionth of a meter.

Natural Gas: A naturally occurring mixture of hydrocarbon and nonhydrocarbon gases found in porous geological formations beneath the Earth's surface, often in association with petroleum. The principal constituent is methane.

NOx: Oxides of nitrogen that are a chief component of air pollution that can be produced by the burning of fossil fuels. Also called nitrogen oxides.

Nuclear Energy: Power obtained by splitting heavy atoms (fission) or joining light atoms (fusion). A nuclear energy plant uses a controlled atomic chain reaction to produce heat. The heat is used to make steam run conventional turbine generators.

Nuclear Power Plant: A facility in which heat produced in a reactor by the fissioning of nuclear fuel is used to drive a steam turbine.

Outage: The period during which a generating unit, transmission line, or other facility is out of service.

Oxides of Nitrogen: See NOx

Particulate Matter (PM): Unburned fuel particles that form smoke or soot and stick to lung tissue when inhaled. A chief component of exhaust emissions from heavy-duty diesel engines 
Petroleum: A mixture of hydrocarbons existing in the liquid state found in natural underground reservoirs, often associated with gas. Petroleum includes fuel oil No. 2, No. 4, No. 5, No. 6; topped crude; Kerosene; and jet fuel.

Plant: A facility at which are located prime movers, electric generators, and auxiliary equipment for converting mechanical, chemical, and/or nuclear energy into electric energy. A plant may contain more than one type of prime mover. Electric utility plants exclude facilities that satisfy the definition of a qualifying facility under the Public Utility Regulatory Policies Act of 1978.

Power: Electricity for use as energy.

Point Source: A stationary location or fixed facility from which pollutants are discharged.

Power Plant (Note: Two separate words, not one word.): A central station generating facility that produces energy.

Price: The amount of money or consideration-in-kind for which a service is bought, sold, or offered for sale

PURPA: The Public Utility Regulatory Policies Act of 1978, passed by the U.S. Congress. This statute requires States to implement utility conservation programs and create special markets for co-generators and small producers who meet certain standards, including the requirement that States set the prices and quantities of power the utilities must buy from such facilities.

Pyroclastic: ${ }^{145}$ Formed by or involving fragmentation as a result of volcanic or igneous action.

Qualifying Facility (QF): A cogeneration or small power production facility that meets certain ownership, operating, and efficiency criteria established by the Federal Energy Regulatory Commission (FERC) pursuant to the Public Utility Regulatory Policies Act (PURPA).

Regulation: The governmental function of controlling or directing economic entities through the process of rulemaking and adjudication.

Reliability: Electric system reliability has two components--adequacy and security. Adequacy is the ability of the electric system to supply to aggregate electrical demand and energy requirements of the customers at all times, taking into account scheduled and unscheduled outages of system facilities. Security is the ability of the electric system to withstand sudden disturbances, such as electric short circuits or unanticipated loss of system facilities. The degree of reliability may be measured by the frequency, duration, and magnitude of adverse effects on consumer services.

Renewable Energy: Resources that constantly renew themselves or that are regarded as practically inexhaustible. These include solar, wind, geothermal, hydro and wood. Although particular geothermal formations can be depleted, the natural heat in the Earth is a virtually inexhaustible reserve of potential energy. Renewable resources also include some experimental or less-developed sources such as tidal power, sea currents and ocean thermal gradients.

${ }^{145}$ Source: USGS 
Renewable Resources: Natural but flow-limited resources that can be replenished. They are virtually inexhaustible in duration but limited in the amount of energy that is available per unit of time. Some (such as geothermal and biomass) may be stock-limited in that stocks are depleted by use, but on a time scale of decades, or perhaps centuries, they can probably be replenished. Renewable energy resources include: biomass, hydro, geothermal, solar and wind. In the future, they could also include the use of ocean thermal, wave, and tidal action technologies. Utility renewable resource applications include bulk electricity generation, on-site electricity generation, distributed electricity generation, non-grid-connected generation, and demand-reduction (energy efficiency) technologies.

Reservoir: A natural underground container of liquids, such as water or steam (or, in the petroleum context, oil or gas).

Resource Conservation and Recovery Act (RCRA): A federal law enacted in 1976 to address the treatment, storage, and disposal of hazardous waste.

Revenue: The total amount of money received by a firm from sales of its products and/or services, gains from the sales or exchange of assets, interest and dividends earned on investments, and other increases in the owner's equity except those arising from capital adjustments.

\section{Scrubber: See Flue Gas Desulphurization Unit}

Selective Catalytic Reduction: A post combustion control to reduce nitrogen oxide gas emissions.

Short Ton: A unit of weight equal to 2,000 pounds.

Sinter: A chemical sedimentary rock deposited by precipitation from mineral waters, especially siliceous sinter and calcareous sinter.

Solar Energy: Heat and light radiated from the sun.

Stability: The property of a system or element by virtue of which its output will ultimately attain a steady state. The amount of power that can be transferred from one machine to another following a disturbance. The stability of a power system is its ability to develop restoring forces equal to or greater than the disturbing forces so as to maintain a state of equilibrium.

Subsidence: A sinking of an area of the Earth's crust due to fluid withdrawal and pressure decline.

System: A combination of equipment and/or controls, accessories, interconnecting means and terminal elements by which energy is transformed to perform a specific function, such as climate control, service water heating, or lighting.

System (Electric): Physically connected generation, transmission, and distribution facilities operated as an integrated unit under one central management, or operating supervision. 
Thermal Pollution: $:^{146}$ a reduction in water quality caused by increasing its temperature, often due to disposal of waste heat from industrial, power generation processes, or urban impervious surfaces (such as parking lots). Thermally polluted water can harm the environment because plants and animals may have difficulty adapting to it.

Transmission: The movement or transfer of electric energy over an interconnected group of lines and associated equipment between points of supply and points at which it is transformed for delivery to consumers, or is delivered to other electric systems. Transmission is considered to end when the energy is transformed for distribution to the consumer.

Travertine: ${ }^{147}$ a mineral consisting of a massive usually layered calcium carbonate (as aragonite or calcite) formed by deposition from spring waters or especially from hot springs

Turbine: A machine for generating rotary mechanical power from the energy of a stream of fluid (such as water, steam, or hot gas). Turbines convert the kinetic energy of fluids to mechanical energy through the principles of impulse and reaction, or a mixture of the two.

Turbine Generator: A device that uses steam, heated gases, water flow or wind to cause spinning motion that activates electromagnetic forces and generates electricity.

Utility: A regulated entity which exhibits the characteristics of a natural monopoly. For the purposes of electric industry restructuring, "utility" refers to the regulated, vertically-integrated electric company. "Transmission utility" refers to the regulated owner/operator of the transmission system only. "Distribution utility" refers to the regulated owner/operator of the distribution system which serves retail customers.

Vapor-Dominated: A geothermal reservoir system in which subsurface pressures are controlled by vapor rather than by liquid. Sometimes referred to as a dry-steam reservoir.

Watt: The electrical unit of power. The rate of energy transfer equivalent to 1 ampere flowing under a pressure of 1 volt at unity power factor.

Watt-hour (Wh): An electrical energy unit of measure equal to 1 watt of power supplied to, or taken from, an electric circuit steadily for 1 hour.

\footnotetext{
${ }^{146}$ Source: Montgomery County, Maryland Department of Environmental Protection

${ }^{147}$ Source: Merriam-Webster dictionary
} 


\section{Index}

abatement, 22, 36, 40, 67

acid rain, 26, 60, 64

air cooling, 5, 6, 7, 25, 33

Air Toxic "Hot Spots" Program, 40

Alaska, 15

ambient air quality standards, 61

Amedee geothermal field, 44

American Lung Association, 24

ammonia, 37

anthropogenic sources, $27,34,36$

Arizona, 15

arsenic, 40

availability factor, 8

A-weighting, 41

barrels of oil, i, 4

baseload, 8, 9, 61, 62

benzene, 37

binary, $3,4,5,7,28,33,43,61$

biomass, 10, 37, 71

bituminous, 35, 64

BLM, ix, 21, 41, 42, 43, 44, 46, 48

Blue Lagoon, 44, 45

boron, 37

brines, 46,53

CalEnergy, 38

California, ii, i, ii, ix, 4, 5, 8, 9, 12, 13, 15, 16, 21, 22, $24,28,31,36,37,39,40,44,49,52,53,54,55$, $57,61,64,69$

California Air Resources Board, ix, 36

capacity, i, 8, 12, 23, 47, 61, 65, 66

carbon dioxide, 32, 34, 39, 65

carcinogen, 37, 40, 65

carrier medium, i, 14

CEC, 9, 12, 36, 38, 64

Cherokee plant, 23, 24

Clean Air Act, ix, 20, 35, 60

Clean Air Mercury Rule, 35

coal, i, ii, 9, 11, 22, 23, 24, 25, 26, 28, 29, 30, 31, 32, $33,34,36,38,46,50,58,59,60,62,64,67,69$

combustion, $22,25,60,62,65,67,68$

construction, $42,43,44,46,52,55,58,59$

cooling system, 6,25

cooling tower, $31,38,42,43$

Coso, 38, 69

cuttings, 41

Department of Energy, iv, ix, 18, 32, 62, 66

direct use, $1,4,16$

drilling, 18, 27, 41, 43, 46, 48, 57, 68, 69

Earth, 2, 3, 4, 7, 13, 14, 15, 18, 40, 44, 45, 46, 52, 57, $65,68,69,70,71$

effluents, 41,44

electrical generation, 3, 4

electricity sector, 9

emissions controls, 23

energy imports, 61

Energy Information Administration, i, 4, 9, 32, 37, 64

Environmental Assessment, ix, 21

environmental costs, 62
Environmental Impact Statement, ix, 21, 41, 47, 48, $51,52,54,55$

environmental regulations, 20, 21

environmental review, iii, 21,58

ethane, 36

farmland, 50

federal land, 21

fish, 35, 40, 49, 59, 60

flash/binary, $7,28,39,48$

fossil fuel, $i, 9,14,22,25,28,30,32,33,40,46,47$, $50,60,61,62$

Fourmile Hill, 21, 51, 52, 53, 54

fumaroles, $27,44,56,57,58$

Geo Venture facility, 7

Geothermal Energy Association, ix, 1, 4, 18

geothermal potential, 1, 16

geothermal reservoir, iii, 4, 5, 6, 14, 32, 43, 45, 46, 52, 53

green power, 60

greenhouse gases, 23, 70

groundwater, iii, 34, 43, 44, 46, 52, 53, 55

Hawaii, 7, 13, 15, 48

Hazardous Air Pollutants, ix, 35

hazardous waste, 36

Healdsburg-Rodgers Creek Fault, 55

health, ii, 24, 26, 27, 28, 30, 32, 35, 36, 40, 49, 60, 62

heat pumps, 1

Heber, 37, 52, 53

hot springs, $4,27,56,58$

hydrocarbons, $36,52,70$

hydroelectric power, $10,12,13$

hydrogen sulfide, 27

hydrogen sulfide abatement, $26,28,36,61$

Idaho, iv, ix, 7, 15, 27

Imperial Valley, 49, 50

induced seismicity, 54

injection, $21,41,44,45,46$

irrigation, 52

isobutane, 5

Italy, 4, 14, 21, 38

Klamath National Forest, 51, 54

Kyoto Protocol, 32

land features, 56,58

land use, 48,51

landslides, 55

Larderello, 4, 14

life cycle, iii, 22, 39, 50

lignite, 35, 69

local water quality, 45

LOCAT, 28

magma, 4, 69

Mahiao, 7

Mammoth Pacific Plant, 24, 48, 49

management, $36,53,55,58,72$

Medicine Lake, 52, 54, 57

mercury, ii, 34, 35, 40

methane, 36, 68, 70

microearthquakes, iii, 54 
mining, $22,30,36,50,51,59,64$

mud, 41, 56

NAAQS, ix, 20, 22, 29

National Emission Standards for Hazardous Air Pollutants, 35

National Energy Policy Act, 14 $3+2$

National Renewable Energy Laboratory, ix

natural gas, $26,27,30,31,33,34,36,47,60,62,65$, $66,67,70$

Nevada, 13, 15, 62

New Mexico, 15

New Zealand, 7, 53

nitrogen oxide, 26

noise muffling techniques, 43

noise ordinances, 42

noise pollution, 41

nonattainment, 20

noncondensable gases, $7,28,32,33,38$

nuclear, $9,46,50,60,67,70$

oil, 10, 18, 27, 28, 29, 31, 33, 60, 65, 70

operation, ii, $27,42,43,46,50,53,54,59,64,66$

Oregon, 15

ozone, 20,68

particulate matter, ix $20,22,23,30,31,39,61,64,70$

petroleum, 10, 27, 67, 70

Philippines, ii, 4, 7

potable uses, 46

power plant, ii, $3,4,5,8,14,22,24,25,28,32,33$,

$38,40,42,43,44,46,49,51,58,60$

propane, 36

Puna, 7, 48, 49

renewable, 2, 3, 4, 10, 14, 60, 61, 62, 63

research, iv, $18,37,55,62,67$

reservoir, $15,25,35,44,73$

respiratory, ii, 24, 26, 29, 60

Richter scale, 54, 55

Risk Management Program, $x$

roads, $51,52,59$

Salton Sea, 37, 49, 53

sand, 41

Santa Rosa, 45, 55

scales, 40

Seismic Monitoring Committee, $\mathrm{x}, 55$

seismicity, iii, 54, 55, 58

silica, 41

sludge, 40,41 solar, $7,9,65,68,71$

solid waste, 39

soot, 30,70

state regulations, 48

Steam Act, 58

subsidence, 44, 52, 53

subterranean temperatures, $16,17,18$

sulfur, ii, 26, 28, 36

sulfur dioxide, $28,29,30,39$

sump, 48

surface features, $44,56,57,58$

sustainability, 45

Sutter, 47

technology, iii, 2, 4, 5, 6, 15, 18, 34, 53, 60, 61, 65

Telephone Flat, 41, 42, 43, 47, 48, 52, 53, 55, 58

The Geysers, 4, 5, 15, 24, 28, 35, 37, 40, 45, 49, 54, 55,61

The Geysers Air Monitoring Programs, 40

transformer, $42,43,65$

transmission, 8, 21, 51, 65, 67, 70, 72

transportation, 9, 22, 50, 59, 62

transporting fuel, 22

turbine-generator building, 42,43

U.S. Geological Survey, 16

Union of Concerned Scientists, $x, 35,62$

units of decibels, ix, 41

Utah, iv, $x, 2,8,15,16$

vapor plumes, 6

vehicles, $25,32,64$

visual impacts, 48, 51, 52

Volatile Organic Compounds, 30

volcanic eruptions, 40

volcanoes, 54

Wairakei geothermal field, 53

waste, $3,9,10,15,22,36,41,45,46,50,64,65,68$

water cooled systems, $5,6,43$

water quality and use, 43

water vapor emissions, 25,48

well pads, 42,50

well-drilling, 42, 43

wellfield, 14, 51, 52, 55, 58

western states, 12,63

Wildlife and Vegetation, 58

wind, 7, 8

Yellowstone National Park, 56, 58 